\title{
SOBRE PRECLUSIONES PROCESALES EN EL DERECHO CHILENO EN TIEMPO DE REFORMAS. ENSAYO DE UNA TEORÍA GENERAL DESDE UN ENFOQUE VALORATIVO JURÍDICO*
}

\author{
Eduardo Gandulfo R.**
}

\begin{abstract}
RESUMEN
El artículo tiene por objeto llenar cierto vacío en la literatura nacional sobre la preclusión, proponiendo, además, un enfoque jurídico valorativo para la comprensión de las formas preclusivas. En este marco, la forma de ensayo ofrece al lector un cuadro de referencia y líneas de posibles discusiones sobre diversos problemas que se plantean en el escrito, en particular, la relación entre desformalización y preclusión. El plan del texto cuenta con una introducción (1), un examen de los fundamentos valorativos de la preclusión (2) y la solución que la preclusión procesal le ofrece (3), continúa con la revisión de la dualidad entre flexibilidad vs. rigidez (4), las etapas y ámbito en que opera la preclusión (5), las fuentes de sus supuestos operativos (6), los tipos de supuestos operativos de preclusión (7), su relación con la congruencia procesal (8) brevemente las formas de hacer valer la preclusión (9), finalizando con la cuestión de si precluye la preclusión (10).
\end{abstract}

\begin{abstract}
The object of this paper is to fill some gap in the national literature about the preclusion, indeed, proposing a legal valuable approach to the comprehension of the preclusives forms. In this framework, the essay's form offers to the reader
\end{abstract}

* Trabajo recibido el 24 de marzo de 2009, y aprobado el 30 de abril de este mismo año.

** Abogado, licenciado de la Pontificia Universidad Católica de Valparaíso. Postgraduado de Especialista en Argumentación Jurídica en la Universidad de Alicante. Profesor de la Universidad Católica del Norte sede Coquimbo. Correo electrónico: ednega@gmail.com. Agradezco la revisión crítica a versiones previas del texto a C. Meneses, C. del Río, F. Carretta, A. Pérez Ragone, O. Salinas y K. Rosenberg. 
a frame of reference and lines of possible discussions about several problems that set out in the document, in particular, the relationship between deformalization and preclusion. The text plan has an introduction (1), an exam of the preclusion's valuable basis (2) and the solution that the procesal preclusion offers it (3), follows with the revision of the duality of flexibility vs. inflexibility (4), the stages and scope in which the preclusion take place (5), the sources of his supposed operatives (6), the types of preclusion's supposed operatives (7), his relation with the procedural consistency (8) briefly, the forms to make effective the preclusion (9), ending with the cuestion if preclude the preclusion.

\section{PALABRAS CLAVES}

Preclusión procesal, tutela jurisdiccional, prontitud del juzgamiento, derecho de defensa, gestión pendiente, cosa juzgada.

\section{KEY WORDS}

Procedural preclusion, judicial protection, promptly to prosecution, right to defense, pending procedure, judged matter.

"Llegará un día en que la humanidad... se asombrará de que los hombres del s. XVIII eran menos avanzados que los de los tiempos de Cesar; este tirano fue muerto en medio del Senado reunido sin otra formalidad que 22 puñaladas, sin otra ley que la libertad de Roma"

L. de Saint-Just (discurso en la Convención Nacional, 13 nov. 1792, sobre el enjuiciamiento de Luís XVI)

\section{1.- Introducción}

Así como en la pretensión de Saint-Just, nuestra tierra también se vio expuesta, luego de 1973, a múltiples enjuiciamientos desformalizados, en contra de cientos o miles de ciudadanos, con diferente suerte para unos y otros. Y es que, en verdad, en este tema, así como en muchos otros, se encuentran enfrentados, de trasfondo, el gobierno de los hombres con el gobierno de la normas. Bajo este último se encuentra la idea de las formas jurídicas, las que delinean en gran medida nuestra civilización ${ }^{1}$. Una parte de suma gravitación de esas formas es la de los procesos de resolución de problemas jurídicos, en vía jurisdiccional. La toma de decisiones en dicha área pasa con mucho por la opción de la presencia o ausencia de las preclusiones procesales, las que contribuyen decisivamente al delineo del proceso mismo.

Sobre la importancia de las formas, vid. R. Summers, "El Lugar de la Forma en los Fundamentos del Derecho", en La Naturaleza Formal del Derecho. Fontamara, trad. Larrañaga, México DF, 2000, pp. 47 a 78. 
Sobre preclusiones procesales en el derecho chileno en tiempo de reformas.

Ensayo de una teoría general desde un enfoque valorativo jurídico.

Históricamente, es sabido que la intervención de la preclusión en la teoría del proceso, ha producido una objetivación respecto a la interpretación de las cuestiones que ocurren al interior de los procesos. En tiempo antiguo, quizá influida por la idea contractual y su interpretación voluntarista, la comprensión de lo que ocurría en el proceso pasaba por explicaciones subjetivas del tipo: 'si el demandado no contesta, se entiende que guarda una pretensión contraria', o 'si las partes no apelan del fallo, se entiende que se conforman con él', o 'si el demandado opone excepción de fondo, se entiende que abandona la dilatoria', todo aunque eso no fuese la voluntad real. La preclusión, hace más de una centuria, ha reemplazado casi totalmente dichas respuestas, mediante soluciones más apegadas a la realidad técnico-procesal, que a interpretaciones psicologistas de la posición de las partes ${ }^{2}$.

Mi pretensión, en este lugar, es de ensayar vías que nos permitan, dentro del marco objetivoformal de la preclusión, dar explicaciones y soluciones que le dispensen valor jurídico a dichas formas, de tal manera que tales explicaciones y soluciones se encuentren cargadas de valor al momento de su aplicación práctica, permitiendo, a su vez, alejarnos de un formalismo vacuo ${ }^{3}$, igualmente pernicioso que la absoluta desformalización, para la concreción de la justicia al destino de los ciudadanos y sus bienes más preciados.

\section{2.- Fundamentos de la preclusión}

La preclusión puede ser enfocada desde diversas perspectivas (como mecanismo, principio, institución o técnica procesal), y así se puede, también, observar distintos aspectos de la misma, lo que la hace difícil de captar teóricamente. En igual medida, también lo variopinto de sus supuestos operativos, hace a la preclusión reconducible a una variedad de razones, las cuales son difíciles de reducir a una sola, como se ha hecho hasta ahora. Los procesalistas, en general, toman como paradigma de nuestra institución, a la preclusión por falta de oportunidad ${ }^{4}, \mathrm{y}$

2 No obstante, las raíces de la preclusión se extienden más extensamente. N. Alcalá-Zamora señala que su construcción fue modernamente elaborada por von Büllow y difundida después por la teoría italiana -en especial Chiovenda-, pero tiene precisamente su origen en la literatura medieval, sobre las fases o tiempos de los procesos, iniciada en el s. XII por Juan Bassiano, Pilio de Módena, Búlgaro de Bolonia y que, en España se puede ver como Jacobo escribe la "Suma de los Nueve Tiempos de los Pleitos", etc. (Proceso Autocomposición y Autodefensa. UNAM, México DF., 1970, p. 106).

3 Sobre los peligros del exceso de formalismo vid. G. Monteleone, "Preclusiones y Debido Proceso. Dos Conceptos Incompatibles", en Proceso Civil, (de la Oliva y Palomo, comp.). Edit. Jurídica de Chile, trad. Ariano, Santiago, 2007, pp. 321 a 327, y A. Romero. 2000. "La Caducidad por Incumplimiento de Cargas Procesales", Revista Chilena de Derecho. v. 27, № 1, año 2000, pp. 419 y 420. Respecto a cargar de valor a las soluciones jurídicas, vid. E. Gandulfo. 2002. "La Validez en los Contextos de Fundamentación y de Aplicación”, Revista de Ciencias Sociales. John Rawls Estudios en su Memoria No 47, pp. 505 y ss.

4 Obsérvese la Ley de Enjuiciamiento Civil española, que en el art. 136 regula, bajo el epígrafe de "La Preclusión", únicamente el caso de preclusión por falta de oportunidad. En nuestro país, algo similar puede verse en las primeras páginas que J. Colombo dedica a la preclusión, Los Actos Procesales, t. II. Edit. Jurídica de Chile, Santiago, 1997, pp. 509 y 514. 
sobre ella construyen su teoría generalizando sus consecuencias. No obstante, dentro de la institución preclusiva, la variante por incompatibilidad constituye la figura más recalcitrante en su reducción, escurriéndose por las esclusas teórico-explicativas, afectando así no sólo a una parte sino a la reconstrucción como un todo.

Todas las versiones de la preclusión tienen que ver con la necesidad de velar por la disposición con que se presentan los actos y resoluciones en el proceso, tanto desde el punto de vista cronológico (p.ej., la presentación en cierto tiempo o la procedencia de un acto, luego de agotada una etapa) como pragmático-lógico (p.ej., la forma de interposición de un recurso de apelación con uno de nulidad o casación en la forma). Tal necesidad es tomada por el Derecho como un valor a lograr y proteger, que llamamos el "orden consecutivo del proceso". Esto es: - desde el punto de vista positivo, que unos actos deban ir primero que otros o junto a otros, y - desde el negativo, que otros posibles actos no se sucedan o no se den junto a otros.

Ese orden consecutivo no es, como tradicionalmente se dice, uno estrictamente "legal", sino que más amplio: se trata de un orden consecutivo jurídico, pues en su conformación concurren diversas fuentes y no sólo la ley (vid. pár. $6^{\circ}$ ). Debemos dejar a salvo algo que todos los operadores de la Codificación sabemos, que la ley juega jerárquicamente un papel prioritario en la configuración de la vida del proceso y así del orden consecutivo jurídico (art. $19 \mathrm{n}^{\mathrm{o}} 3$ inc. $5^{\circ}$ parte $1^{\mathrm{a}}$ y art. $63 \mathrm{n}^{\mathrm{o}} 18$ de la Constitución). Sin embargo, el procedimiento legal exhibe una disímil intervención de la ley en cada tipo de procesos, lo que hace que en algunos sea cuantitativamente su "actor principal" y en otros su acción sea más general y replegada, delegando en otras fuentes normativas la labor configuradora. De esta manera, se puede ver que el orden consecutivo jurídico en los procesos escritos, lo da principalmente la ley, mientras que, en los orales, el juez mediante sus resoluciones particulares (aunque en ambos, no ocurre de manera absoluta). Sin perjuicio de lo anterior, en dicho par de tipos de procesos, el juez es quien vela por el cumplimiento del orden.

Debe tenerse presente, que este orden consecutivo no puede tener cualquier contenido, cuando estamos dentro de los márgenes del Estado de Derecho. En los hechos puede suceder que un juez tome decisiones que miren a la mejor continuidad del proceso para su rápida resolución, pero que dañen a una o ambas partes en sus legítimos intereses jurídicos; p.ej., podría ordenar que se prescinda de la contestación absolutamente, o de toda o una parte de la actividad probatoria del sujeto pasivo, así sin más, pudiendo, simplemente, procederse a la realización de la pretensión sin mayor trámite. El Estado de Derecho rechaza tales aplicaciones y así de la concepción en que se basen ${ }^{5}$. Por tanto, no cualquier orden consecutivo jurídico es

La Corte Suprema, en el caso 'Banco Santander con Recabarren', ha rechazado tales posibilidades, al casar por inconstitucional la sentencia del tribunal a quo sobre el sistema impugnativo de la Ley sobre Prenda de Valores Mobiliarios en relación con el CPC. El tribunal de la instancia interpretó que el art. 6 LPVM, privaba de todo y 
Sobre preclusiones procesales en el derecho chileno en tiempo de reformas.

Ensayo de una teoría general desde un enfoque valorativo jurídico.

válido. Y lo anterior adquiere mayor importancia, cuanto más desformalizados son los procesos y mayor es el poder directivo del juez.

En vistas a lo expuesto, el criterio de Derecho con que se mide el orden consecutivo es el de la corrección. Los actos del proceso se han de desarrollar en un orden racional, esto es, de acuerdo a ciertas razones a que apunta ese orden. El "correcto orden consecutivo jurídico" se refiere a que no cualquier orden que disponga el juez en el caso es válido (sea que se base en una norma legal o no), sino que es el orden que se fundamenta en ciertos valores jurídicos del sistema jurídico (razones de valor). Esto significa que el orden consecutivo no es meramente legal-formal, sino que está conceptualmente construido bajo la influencia de otros valores jurídicos superiores de nuestro sistema, en especial constitucionales, concurrentes sobre este tema. En consecuencia, el orden consecutivo plasma determinados valores que al momento de concretarse la normativa (general o particular), deben concurrir en la comprensión del significado de dicho orden normativo.

El orden consecutivo procesal ocupa un nivel intermedio dentro del Derecho Procesal, por lo que -según se dijo- se encuentra especialmente influido en su construcción por dos macro instituciones (que, a su vez, dan la configuración de prácticamente toda la institucionalidad del proceso y de sus procedimientos): una del tipo técnico-jurídica, la tutela jurisdiccional y otra político-jurídica la del debido proceso (integrada, p.ej., por la prontitud del juzgamiento y la defensa procesal). En suma, el correcto orden jurídico consecutivo mira a la presentación de los actos en el proceso, de manera que dicha presentación permita llegar en el menor tiempo posible, según lo posibiliten las opciones de defensa de las partes, al ejercicio particular de la jurisdicción ${ }^{6}$. En contrario, lo que no afecte a esta configuración así entendida, no afecta al correcto orden consecutivo del proceso, ni dará lugar a la preclusión.

2.A.- La tutela jurisdiccional. El proceso es la vía mediante la cual se realiza la jurisdicción y, por tanto, busca, en definitiva, la aplicación del Derecho al caso particular, mediante una decisión final inmutable y, eventualmente, ejecutarla. Ésta es una de las formas de traer certeza jurídica a la vida de los ciudadanos, cuando ellos no pueden lograrla por sí mismos.

En lo nuclear, la racionalidad del orden consecutivo dice relación con las disposiciones

cualesquier medio de oposición a la realización de la prenda y, por ende, privó al deudor prendario de poder contradecir al banco y de presentar prueba. La corte de casación dictaminó que la sentencia no podía privar de los medios de defensa al deudor, por lo que al actuar así violó el mandato constitucional del debido proceso, en su variante de bilateralidad de la audiencia del art. 19 n 3 inc. 5 CPR, dando como resultado una influencia substancial de tal violación en lo dispositivo del fallo. Sentencia de casación de 13 de agosto de 2008, causa rol 2490-2007, sala civil, redactada por el juez H. Álvarez García.

6 En un sentido similar al expuesto sobre el derecho de defensa, J. Colombo. 2004. "El Debido Proceso Constitucional", Anuario de Derecho Constitucional Latinoamericano № 10, t. I, p. 227. 
sucesivas en que se deban ejecutar los actos y alegaciones necesarios para la instrucción del juzgador, a efectos de la realización de la tutela jurisdiccional en concreto (sea de declaración o de ejecución), o los actos para la cautela jurisdiccional. Fuera de ello no hay más correcto orden bajo este título. Para dichos efectos, en general, el legislador establece ciertas reglas de procedimiento que predeterminan las sucesivas etapas (menos o más gruesas) por las cuales debe pasar un proceso civil, laboral o penal, para su conclusión. Mas, para pasar de una etapa a otra, se vuelve necesario establecer un mecanismo mediante el cual, se produzca el avance del proceso hacia la formalmente correcta decisión final y su eventual ejecución.

Para aquel objetivo se requiere, usualmente, del impulso procesal y de las resoluciones de los tribunales que conduzcan el particular proceso de que se trate. Sin embargo, la sola idea del impulso y de las resoluciones no asegura la ausencia de retroceso en la tramitación de los procesos jurisdiccionales. Tanto el tribunal mediante sus decisiones, como las partes por una cuestión de estrategia, pueden provocar y producir una vuelta atrás en los trámites procesales. Es por ello que surge la necesidad de un mecanismo que consolide los avances hacia la aplicación definitiva del Derecho y no la bloqueen (primera necesidad mediata), logrando así el concreto orden consecutivo dentro de un proceso.

No obstante lo anterior, es insuficiente la sola idea de avance hacia la aplicación de la tutela para la adecuada comprensión. El Derecho contemporáneo cuida que la forma de llegada a tal aplicación sea de una determinada manera (la especificidad de la "forma de la forma"), lo que tendrá consecuencias en la concreción del orden consecutivo (y para la preclusión procesal).

2.B.- El debido proceso. Dentro de las diversas circunstancias de un proceso existen algunas que pueden reñir con una correcta tramitación de un proceso y su orden, sea por causa de las partes o del propio juez. Tales razones han pesado en la construcción histórica de la macro institución del debido proceso. Como señala la afortunada fórmula constitucional, esta institución busca la salvaguarda del racional y justo procedimiento ( $\operatorname{art.} 19$ n 3 inc. 5 CPR). En tal dirección, se han generado una serie de garantías en el Derecho Procesal que tienden a realizarlo (en lo pertinente a nuestro tópico, el derecho de defensa y la prontitud del juzgamiento).

Uno de los valores jurídicos más importantes que tiende a realizar el debido proceso es la certeza jurídica. Ésta constituye un fundamento de dos de las garantías básicas de la construcción del debido proceso, precisamente la de prontitud del juzgamiento y el derecho de defensa. La certeza se refiere a la posibilidad del individuo de prever el desenvolvimiento de su entorno, de acuerdo con ciertas condiciones anteriores previstas. J. Rawls señala que como agentes racionales, una de nuestras características es construir planes de vida, tomando en cuenta expectativas razonables, respecto de necesidades y exigencias futuras hasta donde podamos preverlas. Es decir, actuamos racionalizando nuestra vida, sobre la base de razones, cualquiera que éstas sean. Esto significa que, en Derecho, se nos debe considerar como individuos capaces de dirigir nuestra propia vida, en buena medida. ¿De dónde obtenemos esas expectativas que 
Sobre preclusiones procesales en el derecho chileno en tiempo de reformas.

Ensayo de una teoría general desde un enfoque valorativo jurídico.

juegan como razones? La respuesta de Rawls es apelando al contexto de los individuos: el juzgamiento del individuo para actuar, lo hace a partir de su posición actual en la sociedad y las condiciones normales de una vida humana ${ }^{7}$. Para los efectos que nos importan, esto se abre de dos maneras. La posición actual del individuo en la sociedad puede referirse: tanto a la posición que ocupe en la institución pública del proceso jurisdiccional, como a su vida privada. Si en los tribunales se ventilan las cuestiones que, calificadas de manera abstracta por la ley, son las más importantes en el tráfico y vida jurídica de los ciudadanos, entonces los bienes más preciosos para el desenvolvimiento de los ciudadanos son puestos en juego en los procesos jurisdiccionales. De allí que la suerte de dichos bienes sea de capital importancia, tanto dentro como fuera de los procesos. Es por ello que el debido proceso y sus órdenes consecutivos deben entrar a considerar la formación de dichas expectativas y su protección.

Aquello centra el punto en cuestión, en ciertas garantías que contribuyen a delinear el proceso, a efectos de su correcta consecución: la defensa procesal y la prontitud del juzgamiento.

i) La garantía de prontitud del juzgamiento es una institución que desde dentro del proceso mira hacia afuera del mismo. Ella presenta una específica regulación del proceso, para ciertos efectos respecto de la vida jurídica de los ciudadanos involucrados en los procesos jurisdiccionales. La prontitud obedece al menos a tres necesidades: cubrir la situación de inestabilidad e incertidumbre generada por las condiciones del propio proceso y controlar ciertas externalidades negativas producidas por el tiempo de desenvolvimiento del proceso. a) Mientras esté pendiente el proceso, se encontrarán en juego los bienes jurídicos de los ciudadanos. Esto implica que, ciertos recursos y estados estarán en una situación de inestabilidad sobre su pertenencia o permanencia: casa, dineros, libertad, vida, condición de padre, cuidado de los hijos, etc. Ello plantea, en el mejor de los casos, una restricción en el goce de tales bienes y, en el peor, una exclusión transitoria de tal goce. Y, por supuesto, redunda en una limitación de los recursos para la mantención de la vida propia y de la familia. $b$ ) Pero dado que todo proceso conduce a una sentencia, en donde el juez del Estado de Derecho es un tercero, que no conoce los hechos, en que una de sus características es su ajenidad o desinterés objetivo con las partes, en que su decisión pasará o debe pasar por los medios de corroboración que de hecho logren juntar o disponer las partes, en que tales medios requieren ser interpretados y reconstruidos en el marco de ciertas teorías sobre los casos, en que tal tercero, como humano, es un individuo falible, en que su acceso al Derecho está mediado por la interpretación que deja fuertes espacios a la discrecionalidad en la aplicación del Derecho (y que no contamos actualmente con una teoría que logre su eliminación), en que tal aplicación supone la conjunción de una cierta

J. Rawls, ambas citas de "Prioridad de lo Justo e Ideas del Bien", en Liberalismo Político. FCE., trad. S. Madero, México DF, 1995, pp. 173 y 174. 
cantidad de normas de diverso origen, no conectadas a veces de manera obvia ${ }^{8}$, pues bien, todo ello hace que, en gran medida, el proceso cubra sobre los ciudadanos un cierto manto de imprevisibilidad y así de incertidumbre para la proyección de ciertos aspectos de sus vidas. $c$ ) Se agrega a ello que, el retardo sirve o bien como elemento disuasivo al uso de la tutela jurisdiccional o bien como arma de negociación injusta para la pérdida de los derechos de ciertos ciudadanos en posiciones más desventajosas, en favor de otros de mayor poderío. En especial, ello ocurre en los procesos de Derecho Privado. Así, p.ej., E. Couture decía: "En el procedimiento el tiempo es algo más que oro: es justicia. Quién dispone de él tiene en la mano las cartas del triunfo. Quien no puede esperar, se sabe de antemano derrotado" .

No han pasado inadvertidas tales circunstancias en la línea de trabajo del legislador, dispensándole expreso reconocimiento a este valor jurídico. P.ej., en las modificaciones de 1942 al CPC, ya se señalaba que "la justicia, por definición, tenía que ser expedita y rápida... y que el signo más auténtico de evolución en una sociedad organizada era el que cada ciudadano tuviera conciencia íntima de que en cualquier momento podía hallar amparo oportuno a sus derechos"10. En igual dirección se dirigió la modificación del art. 64 CPC, que convirtió a todos los plazos legales de las partes en fatales. En materia procesal civil de familia, por su parte, la ley permite adoptar de oficio todas las medidas necesarias para la mayor celeridad del proceso (art. 13 LTF). Por otra parte, en materia procesal penal se ha sido especialmente sensible en el discurso, en el sentido de que sin límites a la indagación decía ya el Legislador en el siglo XIX- quien esté siendo sometido a una investigación punitiva, puede pasar el resto de su vida o buena parte de ella, "en una situación incómoda y deshonrosa bajo la amenaza perenne" de perder los bienes más valiosos para la existencia del ciudadano ${ }^{11}$.

$8 \quad$ Sobre el tercero ajeno vid. así, A. de la Oliva, Derecho Procesal Civil, t. I, $4^{\text {a }}$ edic. ECERA, Madrid, 1995, pp. 25 a 27. Sobre la incertidumbre en la cuestión jurídica vid. H. Hart, El Concepto de Derecho, $2^{\mathrm{a}}$ edic. Editora Nacional, trad. G. Carrió, México DF, 1980, pp. 155 y ss; H. Kelsen, Teoría Pura del Derecho, 11ª edic. Eudeba, trads. Nilve y Cabrera, B.Aires, 1973, pp. 164 a 171; R. Dworkin, "El Modelo de las Normas (I)", en Los Derechos en Serio. Ariel, trad. M. Guastavino, Barcelona, 1989, pp. 83 a 94; F. Atria. 1999. "H.L.A. Hart y la Textura Abierta del Derecho", Anuario de Filosofía Jurídica y Social No 17, pp. 379 a 392; y C. Oliva Ekelund. 2000. "La Teoría de la Argumentación y el Positivismo Jurídico", Revista de Ciencias Sociales. Sobre el Razonamiento Jurídico $\mathrm{N}^{\circ}$ 45, pp. 756 a 758. Sobre la incertidumbre en la cuestión fáctica en el proceso J. Frank, Derecho Incertidumbre. Centro Editor de América Latina, trad. Bidegain, B. Aires, 1968.

9 E. Couture, Proyecto de Código de Procedimiento Civil, B. Aires, 1954, p. 37 (citado por J. Montero Aroca. 1975. "La Duración del Proceso Declarativo Civil Español”, Boletín Mexicano de Derecho Comparado N 24, p. 817). En igual sentido, R. von Ihering preguntaba: “¿De qué sirve realizar el derecho de forma eficaz e inapelable, si la lentitud y aparatosidad impiden que el que apela al derecho sólo llega a encontrarlo cuando esté en la tumba?". (“Teoría de la Técnica Jurídica”, en El Ámbito de lo Jurídico, (Moreso y Casanovas, eds.). Crítica, trad. Sanjosé, Barcelona, 1994, p. 61).

10 Mensaje al Proyecto de Modificaciones al Código de Procedimiento Civil de 1942, pár. IV.

11 Mensaje del Proyecto de Código de Procedimiento Penal, pár. XL. 
Sobre preclusiones procesales en el derecho chileno en tiempo de reformas.

Ensayo de una teoría general desde un enfoque valorativo jurídico.

De esta manera, en la construcción del Estado de Derecho se busca poner coto al período procesal, mediante la exigencia de prontitud del juzgamiento. La racionalidad del orden consecutivo mira aquí a que la oportunidad y forma de disposición de los trámites y actos sean las estrictamente indispensables para la más pronta llegada de la tutela jurisdiccional. Dicha prontitud es de carácter "razonable", como dispone el art. 8 n $^{\circ} 1$ de la Conv. Americana de DDHH, por lo que ese rasgo del proceso debe darse no a tontas y a locas, en juicios sumarísimos, sino respetando las debidas opciones del derecho de defensa (de ahí la razonabilidad), de tal manera que se permita una tramitación más corta pero justa de los procesos. No obstante esa contracción de posibilidades y formas, siempre es posible en la práctica que, usando de las mismas, ocurran dilaciones y retrocesos que es preciso evitar (segunda necesidad mediata).

ii) La correcta defensa procesal se refiere a que se pueda intervenir de manera adecuada y eficaz en un proceso, por quien tenga un interés legalmente relevante. Para que se produzca ello, es necesario tener la opción de influir efectivamente sobre el juzgador de la causa ${ }^{12}$, para lo cual el Derecho debe de dotar a los sujetos de ciertas subgarantías o garantías de segundo nivel que desarrollan a esta institución de la defensa. Uno de los elementos constitutivos de dicha institución es el derecho a la información; lo que se relaciona decisivamente con un asunto poco estudiado en la defensa: la estrategia de defensa procesal, como nuclear medio de defensivo. Y ésta, a su vez, tiene que ver en mucho con otro factor clave: las legítimas expectativas procesales.

"Una de las normas básicas del racional y justo procedimiento, que consagra el art. $19 \mathrm{n}^{\circ}$ 3 inc. 5 CPR, es que éste sea precisamente "racional", es decir, que en él se actúe en base a razones que sean posibles de reconstruir y fijar sus expectativas por cualquier agente racional, en particular, el demandante, el demandado o el acusado" ${ }^{13}$. El siguiente contraste nos servirá de ejemplo: un demandado genera su expectativa de defensa respecto de una acción de cobro de pesos y, lo más importante, respecto del contenido típico legal de esta clase de procesos. No obstante, la demanda realmente presentada -elemento que en gran medida fija el contenido del proceso y de la dirección de la sentencia definitiva- pretende

12 "El elemento básico de la defensa procesal es, en nuestra opinión, que los que tengan un interés legítimo en el fallo, por la razón de que se verán afectados por la resolución que se adopte, podrán intervenir para influir en la formación de la decisión del juicio de la causa particular. La determinación del interés para poder gozar del derecho en concreto, se realiza en base a la titularidad de los bienes jurídicos, vgr., orden público, la libertad, etc., que efectivamente están en juego en el proceso... Las ideas de posibilidad de intervención e influencia hacen girar toda la amplia estructura del derecho de defensa". E. Gandulfo. 1999. "Principios del Derecho Procesal Penal en el Nuevo Sistema de Procedimiento Chileno", Revista de Derecho, UCV, No 20, pp. 450 y 451.

13 E. Gandulfo. 2005. "La Aplicación del Principio del 'Venire contra Factum Proprium Non Valet'. Un Caso de Vulgarismo Jurídico", Revista Chilena de Derecho, v. 32, n 2, p. 368 (también en http://dialnet.unirioja.es/ servlet/articulo?codigo=2650397 [visitado el 10.04.2009]). 
una reivindicación. Claramente, la prueba que pueda generar y las excepciones que pueda presentar el demandado, serán irrelevantes en el mejor de los casos, e inadmisibles en el peor si el juicio es reivindicatorio. Asimismo, "la limitación del contenido de lo propiamente discutido, por ejemplo, en la demanda ejecutiva, forma parte de la lealtad en la discusión, para efectos de no sorprender a otro litigante diligente, con un escrito de sobre marcha que contenga una alegación de una norma o calificación, respecto de la cual ese otro no preparó defensa en el momento procesal oportuno"14.

Lo fundamental en esto es la formación de las expectativas procesales justificadas. Tal justificación está basada, en buena medida, en la previsibilidad de las partes en el proceso (certeza jurídica); la que, a su vez, se basa en la información obtenida o suministrada por el actuar de la propia contraparte y del órgano judicial, para la decisión de la construcción y dirección de la estrategia de defensa. Generalmente, para tal objetivo uno se sirve del derecho a la información, que se ejercita, en parte, gracias a la línea discursiva que lleva el proceso. No obstante, se requiere destacar que las estrategias de las partes, en protección de sus propios intereses, están dirigidas en buena medida a sorprender a la contraria, de forma correcta o incorrecta: es decir, afectarle algún elemento, alguna razón que contribuyó a la formación de sus expectativas y que repercuta en su estrategia defensiva, a efecto de que ésta cause la menor influencia posible sobre la convicción del juzgador. Ahora bien, el lector avezado en las prácticas judiciales se podrá dar cuenta que es necesario una protección para la fijación de las expectativas procesales justificadas, que ponga límites a la ampliación, apertura y trueque del contenido argumental que pueda ocurrir mediante los actos procesales ${ }^{15}$. En tal sentido, el orden consecutivo debe establecer, con las oportunidades y formas, una línea de posible debate y eventual progresión, respecto de lo ventilado en el proceso, que las partes sean capaces de reconstruir y seguir como línea discursiva. De ahí que el correcto orden del proceso requiera una línea discursiva, que se logra a través de una restricción formal y temporal de los cambios de dichas líneas argumentativas, en vistas a la precisión, a efectos de evitar las sorpresas ilegítimas que se provoquen para perjudicar la estrategia de defensa de la contraria (y su ejecución), en especial, aunque no exclusivamente, de quien es arrastrado al proceso (tercera necesidad mediata) $)^{16}$.

14 E. Gandulfo "La Aplicación", cit. nota n. 13, p. 369.

15 En parte, esta necesidad la resaltan también, a su manera: P. Calamandrei, Instituciones de Derecho Procesal Civil. EJEA, trad. Sentís, B. Aires, 1962, p. 390, y L. Marinoni, Manual do Processo de Conhecimento. Edit. Revista dois Tribunais, Sao Paulo, 2003, p. 653.

16 En consecuencia, la técnica de la preclusión no está fundada directamente sobre la base de la idea de carga procesal, como se ha implicado equivocadamente, sino directamente en la de correcto orden consecutivo jurídico del proceso, en vistas del progreso a la correctamente formal tutela jurisdiccional, a la salvaguarda del derecho de defensa y de la prontitud del juzgamiento. La idea técnica de carga, no obstante, puede servir como un instrumento concurrente en la plasmación de la técnica de la preclusión procesal. Vid. en contra J. Colombo (Los Actos, cit. nota n. 4, p. 512), que la basa directamente en aquélla. 
Sobre preclusiones procesales en el derecho chileno en tiempo de reformas.

Ensayo de una teoría general desde un enfoque valorativo jurídico.

\section{3.- La preclusión procesal}

3.1.- Todas las antedichas necesidades son satisfechas, en buena medida, por medio de la fijación de ciertas situaciones jurídico-procesales, bajo la precedencia de un correcto orden consecutivo jurídico en el desarrollo del proceso. Este orden se ve desde la perspectiva de la sucesión temporal (como la falta de oportunidad y la consumición frente a otros actos que podría entablar) o pragmático-lógico (como la de incompatibilidad de medios que se presenten conjuntamente). Así, se mira a la correcta disposición formal de los actos y resoluciones, en vistas a permitir el pronto logro de la tutela jurisdiccional y la correcta defensa procesal. A su consecución pueden contribuir varias figuras jurídicas, dentro de las cuales encontramos la preclusión procesal (y a la cual se puede agregar, p.ej., la congruencia procesal).

En la línea de la preclusión, específicamente, la mentada fijación se logra mediante un mecanismo de adjudicación de consecuencias negativas: la pérdida o extinción del poder procesal involucrado, (es la asignación preclusiva) ${ }^{17}$. De aquí podemos extraer tres observaciones:

a) Sobre lo que recae: Precisamente lo que obra aquí es una limitación de los poderes procesales -facultades o potestades- de ejecutar un acto o de dictar una norma o de efectuar una diligencia investigativa o de otro tipo o, incluso, de lograr un cierto resultado ${ }^{18}$.

b) Sobre el tipo de restricción: Dado que se trata de una limitación jurídica, no es que el acto no pueda efectuarse fácticamente, sino que la posibilidad jurídica se ve coartada, pudiendo de hecho realizarse el acto al margen de la juridicidad procedimental (lo que da pie para el análisis del punto 10).

c) Sobre el objetivo: Se trata de una pérdida o extinción, pues el ejercicio del poder de que se trate, mediante la realización del acto o diligencia, es lo que acarrearía lo que se pretende evitar: la contradicción de actos, el retroceso, la repetición o la ambigüedad en la discusión.

Como dice G. Chiovenda, con la preclusión el fin del legislador es dar mayor precisión y rapidez al desarrollo de los actos del proceso, a través de un cierto orden en el desarrollo del mismo. Agrega, que mediante esta figura, la ley "pone límites al ejercicio de determinadas

17 En sentido más o menos similar lo ha entendido la Corte Suprema, al dictaminar que se "define la preclusión como la pérdida, extinción o caducidad de una facultad procesal...". Sentencia de casación de 4 de mayo de 1990, rol 12.684, Gaceta Jurídica (anexo), Nº 119, 1990, p. 7.

18 A. de la Oliva precisa que la preclusión sólo se predica técnicamente para los actos procesales, y no de los derechos sustantivos (Derecho, cit. nota n. 8, p. 163). La razón de ello está en que la preclusión es una institución netamente procesal y que afecta a los derechos o facultades procesales, exclusivamente. 
facultades procesales, con la consecuencia siguiente: fuera de esos límites esas facultades ya no pueden ejercitarse"19. En la misma dirección, E. Liebman señala que la preclusión busca "asegurar al proceso un desarrollo expedito y libre de contradicciones y de retrocesos y garantizar la certeza de las situaciones procesale ${ }^{20}$. En un reciente caso, nuestra Corte Suprema ha seguido tal línea, sentenciando que "debe reiterarse que las necesidades de certeza y seguridad jurídica son inherentes a la resolución de conflictos por medio del proceso, en lo que se basa la preclusión de la impugnabilidad de las sentencias, frente a lo cual se está en la especie" ("Ministerio público con Aarón Vázquez' $)^{21}$.

Debe tenerse presente, que lo que se juzga en la preclusión no es la buena o mala fe de un litigante; eso queda para otras figuras, como, p.ej., el nemo auditur (sin perjuicio de un eventual traslape). Como criterio está excluido aquello. Más bien se trata de enjuiciar el alejamiento respecto de un cierto orden objetivo, que la preclusión busca disciplinar en vista a ciertos fines. Efectivamente, un litigante puede actuar de buena o mala fe, pero ello poco importa en torno al objetivo a proteger. Lo anterior no quiere decir que la forma misma no esté cargada de valor, como ya hemos visto. Esto hace que al volver a observar la preclusión, veamos que sirve, en cierta medida, para disciplinar la conducta de los sujetos procesales, al quedar abarcado un amplio espectro de situaciones en que podría haber, p.ej., mala fe. En ese preciso sentido, entonces es correcto lo que resalta V. Fairén, en orden a que "si no existiese [la preclusión], éste [el proceso] quedaría a merced de la parte negligente o de mala fe" ${ }^{22}$; negligente en evacuar sus actividades procesales propias o debidas o que pretende ir más allá de la leal estrategia procesal.

3.2.- Este esquema conceptual encuentra ciertas consecuencias en la construcción de la idea de preclusión en el ordenamiento procesal en general:

A) La preclusión es una institución general sobre el proceso (G. Chiovenda, V. Fairén y J. Montero Aroca $\left.^{23}\right)$. Esto implica que no sólo opera en los procesos en que prima el principio

19 G. Chiovenda, Instituciones de Derecho Procesal Civil, v. III. Edit. Revista de Derecho Privado, trad. Gómez Orbaneja, Madrid, 1936, pp. 277 y 278. "El ordenamiento jurídico no se limita a regular cada una de las diferentes actuaciones procesales, su forma y su conjunto, sino que regula su sucesión en la relación procesal; de aquí nace un orden legal en los actos procesales". En igual sentido, en sus Principios de Derecho Procesal Civil, t. II. Reus, trad. J. Casáis y Santaló, Madrid, 1922-1925, p. 357.

20 E. Liebman, señala que las leyes procesales actuales están inspiradas "más bien en el principio de adaptabilidad del procedimiento a las exigencias particulares de cada causa", pero ello es de manera que sea compatible con "asegurar al proceso un desarrollo expedito y libre de contradicciones y de retrocesos y de garantizar la certeza de las situaciones procesales", dos objetivos protegidos por la preclusión. Manual de Derecho Procesal Civil. EJEA, trad. S. Sentís, B. Aires, 1980, p. 176.

21 C. Suprema, sentencia de 18 de marzo de 2008, dictada en recurso de queja, rol 6181-2007, (consid. 46).

22 V. Fairén, Teoría General del Derecho Procesal. UNAM, México DF., 1992, p. 408; L. Marinoni, Manual, cit. nota n. 15 , p. 653 , sobre la preclusao.

23 G. Chiovenda, Instituciones, cit. nota n. 19, v. III, p. 407; V. Fairén, Teoría, cit. nota n. 22, pp. 408 y 409 ; J. Montero Aroca, Derecho Jurisdiccional, t. I. Bosch, Barcelona, 1989, p. 532. 
Sobre preclusiones procesales en el derecho chileno en tiempo de reformas.

Ensayo de una teoría general desde un enfoque valorativo jurídico.

dispositivo, sino también en los que rige el orden público. Asimismo, rige en los procesos técnicamente orales o escritos ${ }^{24}$. En consecuencia, esta institución tiene vigencia tanto en los procesos jurisdiccionales civiles, laborales, de familia, administrativos, constitucionales y penales.

No obstante y dado el paso a los procedimientos técnicamente orales desde los escritos, debe resaltarse la distinta disposición en que se halla la preclusión en relación con dichas clases de procedimientos. Porque un error vulgar en la que suele caerse, estriba en creer que el proceso oral es sólo un trasvasije de la sucesión legal de las fases, subfases, sub-subfases, etc. del escrito (en donde cada acto es una sub-sub-subfase, como la presentación de una lista de testigos) a un medio verbal, con bloques que cuenten con la misma rigidez de este último. Veremos a lo largo del texto que aquello no es así. Una primera aproximación descriptiva más precisa, de las situaciones normativas en una y otra clase de proceso es la siguiente: en los orales, hay una tendencia a un orden legal mínimo, y en los escritos, una tendencia al orden legal máximo ${ }^{25}$ :

i.- $\quad$ En la construcción tradicional de los procesos orales rige como conjugación característica -en lo que nos interesa- los criterios de: concentración, de relativa desformalización y de delineamiento garantista, lo que hace que los concretos procesos se estructuren y desarrollen de determinada manera (vid., p.ej., arts. 9 y 11 LTF, y art. 425 CdT).

La oralidad tiene como objetivo lograr una mejor forma de impartir justicia, en tanto permitiría que el juez pueda captar de manera inmediata y flexible el devenir del proceso. Pero la oralidad misma implica al juez centrarse en un caso a la vez, lo que puede retrasar aún más la impartición de justicia, desde la perspectiva de la globalidad del sistema judicial.

Frente a ello, la idea es concentrar los actos en unas pocas audiencias y dotar de flexibilidad a los procesos particulares, de tal manera de que éstos puedan adaptarse al devenir de las singulares circunstancias, logrando así una mayor continuidad de las audiencias. Veámoslo más detalladamente.

En cuanto a la concentración, se trata de que los actos del proceso se desenvuelvan de

V. Fairén Guillén, Teoría, cit. nota n. 22, p. 406; J. Montero Aroca. 1997. "Síntesis de Derecho Procesal Civil Español”. Boletín Mexicano de Derecho Comparado No 89, p. 668, y A. Carocca, Manual de Derecho Procesal Civil, t. II, Los Procesos Declarativos. Lexis Nexis, Santiago, 2003, p. 45.

25 No sigue esta tendencia (más bien por desidia legislativa) el procedimiento que regula los procesos ante el Tribunal Constitucional, el cual es fundamentalmente escrito (art. 27 LTC), con ciertas normas mínimas de procedimiento, pero que, en varia materias, es el propio Tribunal el que debe determinar las medidas del caso para la más adecuada sustanciación y resolución, pudiendo fijar incluso su propio procedimiento para cada causa (art. 30 inc. 1 LTC). 
forma agrupada en el tiempo, en audiencias (y dentro de cada audiencia no hay plazos legales divisorios, sino que es continua). Idealmente, se desarrollan en una audiencia o en la menor cantidad de audiencias posibles, cercanas en el tiempo; se evita así la separación de las actuaciones (incluyendo en principio las revisiones recursivas ${ }^{26}$ ) y se gana en celeridad.

La tipicidad procedimental ordinaria contempla dos audiencias ${ }^{27}$ : la de preparación del juicio oral (art. $61 \mathrm{LTF}$, art. 260 y ss. CPP y art. 453 CdT), y la de juicio oral (art. $63 \mathrm{LTF}$, art. 325 y ss. CPP y art. 454 CdT). Por la concentración se trata de establecer un orden legal mínimo al proceso, fijando temas de orden racional para la decisión final, reglas de flexibilidad y el resto se deja a la dirección del juez (limitada por las garantías procesales). Así, la primera audiencia tiene por función, evitar razonablemente la tramitación completa del proceso, delimitar y fijar el tema de la decisión -incluso reduciéndolo- y delimitar y fijar el tema de la prueba. Por consiguiente, se evacuan o ratifican los actos del posible debate -previos o de fondo-, se ventila el llamado a conciliación y se realiza ofrecimiento de los medios de prueba; termina con el dictado de la correspondiente resolución de apertura del juicio oral (art. 62 LTF y art. 277 $\mathrm{CPP}$ ), cuando éste sea procedente. La segunda tiene por objeto evacuar los medios de prueba, los alegatos de clausura y dictar el fallo (arts. 64 a 65 LTF, arts. 296, 338 y 343 CPP, arts. 454 y 457 CdT). a) Desde el punto de vista interno de cada audiencia, si bien rige la continuidad de la misma, para determinados efectos del debate y del ejercicio del derecho de defensa, podemos identificar algo así como "fases" que engloban una serie de actos, que configuran la idea de orden mínimo y que permiten el avance de la propia audiencia hacia su resolución final. $b$ ) Desde el punto de vista externo de las audiencias, no obstante que los actos procesales se deben concentrar en las audiencias, cada una tiene internamente sus propios tópicos que no posee la otra (en materia penal se repiten ciertos actos). a) Así, en la perspectiva interna, se requiere que las "fases" se vayan consumiendo para poder concluir la audiencia, y que quede fijo el material sobre el cual las partes podrán debatir y seguir su estrategia. $b$ ) A su vez, en lo externo, es importante que la especificidad de contenido de la audiencia preparatoria no se vuelva a repetir, en general, en la audiencia de juicio oral, para no afectar las expectativas de las partes y no dilatar el proceso.

Desde la perspectiva de la flexibilidad y según lo visto, se restringen las formalidades generales de la audiencia al mínimo necesario para servir a los valores antes indicados; de ahí, en parte, la "relatividad" de la desformalización. Pero, también, con ello, de pasada se afecta en forma restrictiva la extensión de la procedencia del mecanismo de la preclusión. Así, p.ej., en la audiencia preparatoria, al momento de ofrecer los medios probatorios por una de las

\footnotetext{
26 Sobre la posibilidad de recurrir en juicios concentrados, vid. M. Damaska, Las Caras de la Justicia y el Poder del Estado. Edit. Jurídica de Chile, trad. A. Morales, Santiago, 2000, pp. 93 a 96 y 101 a 103.

27 Puede también, eventualmente, haber otras audiencias, como sobre medidas cautelares o de recepción de prueba anticipada, o de comunicación de la sentencia definitiva.
} 
Sobre preclusiones procesales en el derecho chileno en tiempo de reformas.

Ensayo de una teoría general desde un enfoque valorativo jurídico.

partes, si, vgr., ya ofreció sus testigos y está ofreciendo una pericia, puede, por la desformalización y continuidad, ofrecer otro testigo más que hubiese omitido, sin que le haya precluido dicha opción. La razón está en que al ser la audiencia continua y flexible, cada acto no se identifica con una sub-sub-subfase, como en el proceso escrito (la gran limitación viene dada por el derecho de defensa y las expectativas de las partes).

El gran articulador del orden continuo en las audiencias y así del impulso procesal es el poder directivo del juez (A. Wach) ${ }^{28}$, que concreta, en parte, la relativa desformalización. Es el juez quien "deberá dar curso progresivo al procedimiento [proceso]" (art. 13 inc. 2 LTF), pues posee poderes oficiosos y cierta discrecionalidad para dirigir la audiencia y la presentación de los medios de defensa (alegaciones y medios de pruebas), en base a las necesidades técnicoprocesales de las eventuales discusiones jurídicas (art. 292 CPP, art. 26 bis LTF y art. 429 CdT), en especial, para evitar dilaciones indebidas (art. 430 inc. 2 y 3 CdT), para efectos de la mayor celeridad (art. 13 LTF), reduciéndose así el ámbito de la preclusión. Por tanto, es el juez quien pone las particulares formalidades. No obstante, la discrecionalidad no es una competencia absoluta en el Estado de Derecho, sino que se encuentra rodeada o encapsulada dentro de los marcos de la juridicidad, según manda el art. 7 CPR. A causa del delineamiento garantista de los procesos, el juez del Estado de Derecho queda vinculado al contenido técnico de las garantías y principios de rango constitucional o legal, por lo que su dirección debe ser siempre permitiendo la opción al derecho de defenderse de cada parte, protegiendo, entre otras cosas, las expectativas procesales legítimas que se formen en el devenir de la discusión de la audiencia (paradigma de lo expuesto es el CPP, cuya técnica está en que, por una parte, regula el rito procedimental de las audiencias en unos pocos artículos y, por otra, destina muchos a contemplar las garantías de las partes) ${ }^{29}$. Tal directriz, la legislación la reconoce normando que, los poderes restrictivos del juez podrán ser utilizados, "pero sin coartar el ejercicio de los litigantes para defender sus respectivas posiciones" (art. 26 bis inc. 1 p. $2^{\mathrm{a}}$ LTF), "sin coartar el ejercicio de la acusación o ni del derecho de defensa" (art. 292 inc. 1 p. $2^{\text {a }}$ CPP), o cuidando que la forma del emplazamiento al demandado "garantice el derecho a la defensa y los principios de igualdad y bilateralidad de la audiencia" (art. 439 CdT.). Además, el garantismo hace que las fases dentro de cada audiencia, tengan una desigual flexibilidad comparadas unas con otras. $\mathrm{Y}$ es precisamente ello lo que da pie para el ingreso de la preclusión (en especial, por consumición), justamente por la ratio iuris de defensa procesal y prontitud del juzgamiento.

28 A. Wach, Conferencias sobre la Ordenanza Procesal Civil Alemana. EJEA, trad. Krotoschin, B. Aires, 1958, pp. 7, 40, 72 y 77. En igual línea, se señala que en Inglaterra, con la reforma de las Civil Procedural Rules 1998, al juez le "vienen confiados numerosos e incisivos poderes de gobierno y dirección del procedimiento, como aquél referido a la determinación del track que la causa deberá seguir (o sea, del tipo de procedimiento aplicable según la naturaleza de la causa), a la fijación de las audiencias y la obtención de las pruebas", y lo mismo se puede predicar de USA (M. Taruffo. 2006. 'El Proceso Civil de 'Civil Law' y de 'Common Law': Aspectos Fundamentales", Ius et Praxis $\mathrm{N}^{\circ} 1$, año 12, pp. 64 a 94).

29 El delineamiento garantista no queda marcado de manera exclusivamente ritualista-procedimental, sino también procesal. 
Es por todo lo expuesto que se reconoce que, en los juicios orales "la concentración del contenido del proceso no debe nunca ser confundida con el caos, mezcolanza de alegaciones, pruebas y conclusiones sin orden; esto es, dentro de la misma 'concentración' deben admitirse 'preclusiones', momentos procesales a partir de los cuales ya sea imposible retroceder y, por ejemplo, formular alguna alegación o pedir alguna prueba más"30. Además, es menester reiterar la consideración de que no podemos tener, legítimamente, un poder discrecional absoluto del juez que pudiese afectar el principio de igual protección del Derecho (art. $19 \mathrm{n}^{\circ}$ 3 inc. 1 CPR). Un litigante puede ser privado de, p.ej., el acto de contestación y otro no, frente a tardos arribos a audiencias. Sin reglas de preclusión, ni reglas de formalización del proceso, la procedencia de dicho acto quedaría radicada en el mero criterio personal del juez, que puede adoptar una decisión ' $a$ ' como 'no- $a$ ', en diversas ocasiones; se pone así al proceso de impartición de justicia bajo el gobierno de los hombres excluyéndolo del imperio de la legalidad, cayendo en un grave retroceso en la evolución procedimental ${ }^{31}$.

ii.- Por su parte, en los procesos escritos lo que prima es la dispersión de los actos (en oposición a la concentración): “el procedimiento escrito exige que se establezcan una serie de lapsos... para que cada parte realice el correspondiente escrito y se comunique a la otra parte, y lo mismo cabe decir de las resoluciones del juez. El procedimiento se dispersa así en fases o tiempos" ${ }^{32}$, exclusivamente. En tal sentido, cada acto del proceso viene a constituir una sub-sub-fase del proceso mismo. Frente a esa dispersión es la ley la que toma las riendas del asunto, estableciendo un orden legal máximo sobre el orden del proceso. En concordancia con tal línea de decisión, para su concreción práctica, se ha estimado que sea necesario un mecanismo articulador de la sucesión, contemplado principalmente en abstracto, que le dé unión temporal a la dispersión de fases haciendo avanzar al proceso: la preclusión legal.

B) La preclusión se aplica tanto a los poderes procesales de los privados que actúan con base en sus derechos, como a quienes deben actuar en base a un deber jurídico, (vgr., fiscales del Ministerio Público, los abogados del Consejo de Defensa del Estado y, en general, los abogados de los servicios públicos).

30 V. Fairén Guillén, Teoría, cit. nota n. 22, p. 406; J. Montero Aroca, "Síntesis", cit. nota n. 24, p. 668; en igual sentido A. Carocca, Manual, cit. nota n. 24, p. 41.

31 Así, la idea es intentar excluir ciertas situaciones y consideraciones en base a la incertidumbre, como las derivada del principio de unidad del debate, que da cuenta L. Rosenberg en el Derecho alemán. La extensión continua e ilimitada prima facie del debate oral, se limita "porque las partes no pueden saber cuándo considerará el juez al proceso en condiciones de resolución... y mediante el cierre del debate oral, les suprimirá de seguir alegando" (Tratado de Derecho Procesal Civil, t. I. EJEA, trad. Romera, B. Aires, 1955, p. 407; la cursiva es mía). Sobre este principio en materia procesal penal, vid. J. Baumann, Derecho Procesal Penal. Depalma, trad. Finzi, B. Aires, 1986, pp. 101 a 105.

32 J. Montero Aroca, "Síntesis", cit. nota n. 24, p. 668. 
Sobre preclusiones procesales en el derecho chileno en tiempo de reformas.

Ensayo de una teoría general desde un enfoque valorativo jurídico.

Incluso se aplica al propio tribunal respecto de sus poderes procesales (J.R. Podetti y F. Hoyos Henrechson $^{33}$ ). Los fundamentos están en vistas del objetivo protegido, del correcto orden consecutivo procesal, y que el objeto afectado por la preclusión son los poderes procesales (como de dictar resolución). Así, también lo ha dictaminado la Corte Suprema: en vistas a la "preclusión", el "orden para los actos procesales... debe respetarse tanto por las partes como por el tribunal" 34 .

En general, no es que opere de manera directa sobre el tribunal con respecto al uso incompatible o no uso de alguna potestad -vgr., los plazos para resolver, según el art. 64 inc. 1 parte $1^{a}$ CPC-, sino que principalmente de manera refleja por la actuación de las partes

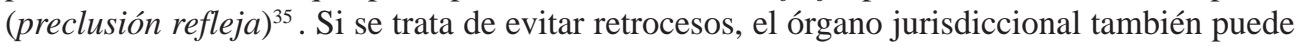
ordenar, con base en el art. 84 CPC y a las normas de casación o nulidad, la vuelta atrás del proceso. Es por ello que, la propia ley se ha encargado de limitar sus poderes, en el sentido de que el tribunal no puede suplir la actividad precluida por falta de oportunidad de las partes. Según R. Tavolari, esto significa que precluida para las partes, p.ej., la facultad de impugnar de nulidad una resolución, también queda el juez privado de su potestad de corrección ${ }^{36}$. Tal proyección dual la prescribe expresamente la ley, en el caso de preclusión de los conflictos de competencia territorial, como enuncia el art. $74 \mathrm{CPP}^{37}$. Lo mismo ocurre con los autos y decretos, en que una vez que no son impugnados en el tiempo legal, según el art. 181 inc. 1 CPC, adquirirán el carácter de "firmes" y "se mantendrán" así (salvo el caso excepcional del inc. 2 del art. 181 CPC). P.ej., si la corte decreta admisible un recurso de casación o apelación en su examen in limine litis -o aún en recurso de hecho- (arts. 781, 201, 213 y 205 CPC), si no es impugnado dicho decreto en tiempo y forma, es decir, pasada esa etapa, ya no se podrá volver a examinarla cuando resuelva sobre el fondo del recurso, por lo que no podrá revocar el decreto y deberá mantener su contenido vigente (la única opción sería anularlo, pero ello importa someterse a otro régimen, el de nulidad procesal, con las limitaciones propias del "perjuicio" y la "convalidación"). De esta guisa, podemos decir que donde hay preclusión refleja opera un

J.R. Podetti. 1947. "Preclusión y Perención", Revista de Derecho Procesal. $3^{\text {er }}$ y $4^{\text {er }}$ trimestre, p. 366. F. Hoyos Henrechson, Temas Fundamentales de Derecho Procesal. Edit. Jurídica de Chile, 1987, p. 211.

34 C. Suprema, sentencia en causa rol 12.684, cit. nota n. 17, p. 7 (la cursiva es mía).

35 Esto no obsta a que, a través de otros mecanismos, como el desasimiento del tribunal, puedan lograrse otras limitaciones de las facultades procesales.

36 R. Tavolari. 1991. "Reflexiones Actuales sobre la Nulidad Procesal", RDJ, t. 91, nº 1, 1ª parte, pp. 6 y 7.

37 Así también lo entendió la Corte Suprema, de la mano del juez N. Segura, que rechaza el recurso de nulidad de la sentencia impugnada, a causa de la preclusión operada ante los jueces de la instancia, lo que le hacía imposible incluso a dicha Corte alterar ese punto: "cobra particular vigencia la norma perentoria del artículo 74 del [CPP] que dispone la preclusión de cualquier conflicto de competencia cuando declara que transcurrido tres días desde la notificación de la resolución que fijare fecha para la realización de la audiencia del juicio oral en lo penal, la incompetencia territorial del tribunal oral en lo penal no podrá ser declarada de oficio ni promovida por las partes, lo cual cierra este capítulo de objeción y decide su rechazo". Sentencia del 10 de agosto de 2005, rol 2592-05, caso 'Ministerio público con Guerrero Barrera y Jorquera Sánchez'. 
cercenamiento de poderes del tribunal quedando así limitada su competencia, dando fijeza y orden al proceso.

No obstante, la ley sí puede atribuir una consecuencia preclusiva directa al juez (Podetti ${ }^{38}$ ), por falta de ejercicio de alguna potestad procesal o por su efectivo ejercicio, precisamente con el objeto de cubrir la ratio iuris de esta figura. Si bien lo normal es que el tribunal no incurra en preclusión por faltar a su deber procesal de oportunidad, debido a una decisión político-jurídica de la ley, como señalan los arts. 64 inc. 1 parte $1^{\text {a }} \mathrm{CPC}$ y 435 inc. $1 \mathrm{CdT}$, ello no excluye la posibilidad de que el legislador pueda tomar una decisión en dirección contraria. Cuatro clases de casos nos pueden servir como medios de contrastación para la tesis. A.- El Código Procesal Penal establece dos casos de oportunidad: $i$.- cuando no se dicta el veredicto al término de la audiencia de juicio o dentro del plazo de 24 horas, el tribunal pierde la potestad de dictarlo (y se atribuye, conjuntamente, nulidad al proceso) según el inc. 2 y 3 del art. 343 CPP; ii.- si no se redacta el fallo condenatorio y/o o no se comunica en la audiencia respectiva, dentro de los plazos o términos fijados por la ley, el tribunal no tendrá la potestad para emitir eficazmente dicho fallo luego (y se atribuye al proceso nulidad) de acuerdo al art. 344 inc. 1 CPP. B.- En materia civil, está el desasimiento del tribunal, en que se puede estimar que hay una consumición preclusiva de las facultades resolutorias del tribunal, una vez usadas y notificada la sentencia definitiva o interlocutoria (art. $182 \mathrm{CPC}$ ). La consecuencia es que el juez no puede volver a usar el poder procesal de dictar otra sentencia o de mutarla, en el mismo proceso (M. Libedinsky) ${ }^{39}$. Tal explicación logra una reducción explicativa exitosa a ciertos conceptos fundamentales. $C$.También se señala el plazo para decretar medidas para mejor resolver del inc. 1 del art. 159 CPC: "En este único caso, la Comisión Conjunta [de reforma al CPC] estableció que el plazo para que el tribunal haga uso de esta facultad es fatal para éste" (M. Otero $)^{40}$.

3.3.- Régimen temporal. La operatividad de la preclusión es siempre desde el presente hacia lo futuro, nunca teniendo efecto retroactivo, se dice por Podetti ${ }^{41}$. En general, es relativamente claro entenderlo así: tratándose del no cumplimiento del plazo legal, estando fuera de plazo se extingue la opción; la contradicción de actos, al incurrirse en ella se produce el supuesto preclusivo; o en la consumición al ejecutar el acto, se entiende consumirse la facultad (con la salvedad que diremos más adelante).

No obstante, existe un caso que podría dar pie a duda: la preclusión por rebeldía del plazo judicial (art. $78 \mathrm{CPC}$ ). La resolución que la constituye, podría retrotraerse al momento en que

\footnotetext{
38 Así también J.R. Podetti, “Preclusión”, cit. nota n. 33, p. 366.

39 M. Libedinsky. 1986. "Límites a la Facultad de los Jueces para Aclarar o Rectificar de Oficio sus Sentencias", Gaceta Jurídica $\mathrm{N}^{\mathrm{0}} 72$, p. 2.

40 M. Otero, Derecho Procesal Civil. Edit. Jurídica de Chile, Santiago, 2000, pp. 80 y 81.

41 J.R. Podetti, "Preclusión", cit. nota n. 33, p. 369.
} 
Sobre preclusiones procesales en el derecho chileno en tiempo de reformas.

Ensayo de una teoría general desde un enfoque valorativo jurídico.

fue, o bien, acusada la rebeldía, o bien, constatada. Sin embargo, la teoría procesal se manifiesta contraria a dicha solución, basados en una decisión conceptual y un argumento de texto. La concepción es que no se está en rebeldía, sino cuando se la decreta así. p.ej., C. Anabalón señala que en estos casos, la resolución es necesaria para que se declare un trámite en rebeldía de alguna de las partes, a efectos de dar curso progresivo al proceso, sino se produciría el entorpecimiento o paralización del mismo, o bien, se omitiría un trámite o diligencia que podría perjudicar seriamente al contendor cuando ello no importara, todavía, una causal de nulidad del procedimiento ${ }^{42}$. De consiguiente, como agrega F. Alessandri: "Mientras la rebeldía no se declare el término no ha expirado y el litigante puede evacuar el trámite que corresponda". Y señala que el trámite no legal de la certificación del secretario, sólo da más tiempo a la parte para cumplir ${ }^{43}$. Corrobora lo expuesto el que la certificación no sea un trámite legal pertinente, pues lo excluye el texto del art. 78 CPC ("proveerá la que convenga para la prosecución... sin certificado previo del secretario"); su presencia en el proceso es meramente contingente, dando cuenta sólo de un hecho pasado, pero no de un hecho postrero a éste previo a la resolución constitutiva. En suma, la mencionada resolución constitutiva de la preclusión por rebeldía, no tiene en nuestro Derecho un tratamiento retroactivo ni al tiempo de su acusación, ni al de la constatación ministerial.

3.4.- Tipos de preclusiones. A mi juicio, existen dos tipos de preclusiones: una absoluta y otra relativa, determinadas desde el punto de vista de la extensión del ámbito de la preclusión.

3.4.1) La absoluta se refiere a que la facultad procesal se extingue completamente para todo caso. En estas situaciones, todo el haz de medios o actos (alegaciones, recursos, medios de prueba, incidentes) se extingue completamente. Por ejemplo: a) cuando se ha llegado a la sentencia de término y no queda ningún otro medio que hacer valer, por parte del perdidoso; b) en los juicios de única instancia civiles, cuando transcurre el término probatorio se extingue por completo la conjunción de ofrecer y presentar a la vez la prueba; c) transcurrida la oportunidad para contestar, se pierde absolutamente tal facultad.

C. Anabalón, Tratado Práctico de Derecho Procesal Civil Chileno, v. I, 2ª edic. Librotec, Concepción, 1966, p. 211. F. Alessandri, Reglas Comunes a Todo Procedimiento y del Juicio Ordinario, pp. 43 y 44, Imprenta El Esfuerzo, Santiago, 1934. Reafirma lo anterior C. Anabalón, al señalar que: "Aun más, puede darse la coyuntura de haber recaído ya resolución favorable a la acusación de rebeldía; mas sin aparecer todavía aquélla notificada en la forma y oportunidad debidas, en cuyo momento entra al despacho con carácter de urgente, la solicitud del rebelde. También en este caso, de acuerdo con la regla del Art. 38, se impone el pronunciamiento judicial sobre esta última solicitud, dejándose sin efecto la resolución dictada sobre la primera" (Tratado, cit. nota n. 42, p. 213). El § 231 de la ZPO alemana (de procedimiento oral) señala en su numeral $1^{\circ}$ que las consecuencias de inobservar un plazo "se producen por sí mismas en tanto esta ley no exija petición de parte para la realización y la consecuencia jurídica perjudicial" y agrega su n 2 que: "En este último caso se puede recuperar la posibilidad de realizar el acto procesal omitido, en tanto no se interponga la petición y esta sea decidida en audiencia oral" (Código Procesal Civil Alemán. KAS, trad. A. Pérez y J. Ortiz, Montevideo, 2006). 
3.4.2) Pero existe una preclusión relativa. Se trata de la situación en que la ley no extingue todo medio, sino que deja abierta una posibilidad.

i) En particular, puede tratarse que se deje abierto un medio extraordinario, dentro de la misma instancia; son casos de flexibilidad preclusiva. Se puede dejar subsistente un recurso procesal que no se agota o se permite que el tribunal admita el resurgimiento de un medio por circunstancias extraordinarias, todo dentro de la misma instancia. a) La primera variante se puede observar en el caso del art. 181 CPC. Guardando la armonía del articulado del CPC, podemos decir que cuando se han acabado los medios normales de impugnación de una resolución, entonces una resolución se encuentra firme (reinterpretando lo señalado por el art. 174 CPC en relación con el art. 181 CPC). Pero tales medios de impugnación son los que contempla usualmente el ordenamiento y que cuentan con un plazo o término de interposición. La idea de firmeza se halla indisolublemente ligada a la preclusión procesal, por ello es que cuando han precluido los medios de impugnación (y notificada la resolución), entonces la resolución se encontrará firme o inmutable. El art. 181 inc. 1 del CPC establece como supuesto operativo y, por ende, requisito, para la ejecución de un auto y decreto, el que tales resoluciones se encuentren "firmes": "Los autos y decretos firmes se ejecutarán y mantendrán desde que adquieran este carácter". Dichas resoluciones son susceptibles de recurso de reposición, dentro del plazo de 5 días según el art. 181 inc. 2 CPC (y, eventualmente, apelación, art. 188 CPC). Pasado dicho plazo sin interposición alguna, puede ejecutarse el auto o decreto: esto es, de acuerdo a su concepto, permiten darle curso progresivo al proceso o resolver un incidente o anomalía en el mismo. Es decir, pasada la opción de las impugnaciones opera la preclusión y se da curso al proceso. En lo que toca a la relativización, si consideramos que, de acuerdo al propio inc. $1^{\mathrm{o}} \mathrm{del}$ art. $181 \mathrm{CPC}$, siempre se puede interponer el medio de impugnación, basado en nuevos antecedentes, esto significa que tal medio no tiene plazo de preclusión y, por tanto, nunca podrá haber firmeza preclusiva; de guisa, no podrá operar el supuesto de ejecución de tales resoluciones y, por ende, no podrá haber curso progresivo del proceso. Tal interpretación conduce a un absurdo práctico. Sin embargo, podemos entender que estamos en presencia de un medio en una situación absolutamente anormal, sobre el cual la preclusión absoluta no opera -por razones de flexibilidad. En tal sentido, sí puede entenderse que hay una preclusión relativa, respecto a los plazos o términos establecidos desde la notificación de la resolución, y ligarlos, entonces, con la idea de firmeza. El sentido del inc. 1 es de señalar el resurgimiento de la facultad previamente precluida, situación que ocurriría cuando se tenga a disposición los nuevos antecedentes (situación en que se sometería de nuevo al régimen normal). b) La segunda variante son ciertos casos en que la ley faculta directamente al tribunal para admitir algunos medios, cuando precisamente estaban precluidos. Si la preclusión fuera absoluta, la opción sería imposible. Pero cuando existen ciertas circunstancias no imputables a la parte, se permitirá abrir la posibilidad del ejercicio de la facultad procesal. El caso más típico se da en materia de medios probatorios: luego de ofrecidos todos en la audiencia preparatoria, queda precluida 
Sobre preclusiones procesales en el derecho chileno en tiempo de reformas.

Ensayo de una teoría general desde un enfoque valorativo jurídico.

la opción de presentar otros; no obstante la ley permite su excepcional presentación fuera de la ritualidad regular, según disponen los arts. 336 CPP y 62 inciso final $\mathrm{LTF}^{44}$.

ii) La otra circunstancia de preclusión relativa se da cuando se extingue un tipo de facultad procesal relativamente a una cierta instancia procesal, pero no a otra instancia. Para los efectos preclusivos y su relación con el avance del juicio, la facultad procesal de hacer valer un medio se pierde dentro de una cierta etapa. Lo importante es que su carácter preclusivo está precisamente en la necesidad de esa pérdida para que avance el proceso; sin ella el proceso no avanzaría hacia la siguiente etapa, fase o conclusión. No obstante dicha pérdida o extinción, el Derecho la circunscribe o limita sólo a determinada etapa o fase, por ciertas razones especiales que en cada caso pesan. Esto significa que se puede hacer valer ese medio en otra etapa o fase, de ahí su relatividad. Corrobora esta idea la Corte de Apelaciones de San Miguel, que sentenció, respecto a un medio procesal precluido en primera instancia y cuya presentación es permitida en segunda (una excepción anómala de prescripción), que "no existe impedimento legal para que pueda volverse a plantear en segunda instancia, antes de la vista de la causa (como ha ocurrido), máxime, si aparece desestimada en la sentencia recurrida por 'falta de oportunidad', con lo cual debe rechazarse la oposición a interponer que hace la actora" ${ }^{45}$. Pero -como el lector podrá darse cuenta- es indispensable que dicha otra etapa o fase, a que hago referencia, exista en el procedimiento y que se dé efectivamente en el proceso, para que exista esta flexibilidad.

Los casos a que me refiero pueden también ser ejemplificados en la prueba del proceso civil escrito, especialmente, por la facultad de presentar documentos y de citar a absolver posiciones. En la primera instancia del proceso (etapa) ellos deben ser ventilados hasta el fin del término probatorio (la absolución de posiciones podría pasarse un poco más); citadas las partes para oír sentencia, éstas ya no tienen la facultad de presentar más documentos válidamente en general, ni pedir la absolución de posiciones y dictada la sentencia definitiva tampoco pueden hacerlo en primera instancia. No obstante, el Derecho Procesal permite a las partes una vez cerrada la primera instancia, volver a presentar documentos y solicitar la absolución de posiciones, pero ahora en segunda instancia, es decir, en otra etapa. Esto muestra que la preclusión operó validamente en una etapa, logró su objetivo de hacer avanzar el proceso a la

C. Pecchi Croce, comentando sobre la flexibilidad operada en la preclusión, en orden a aceptar ciertas deducciones tardías, señalaba que son razones superiores de justicia las que aconsejan que se admitan estos medios tardíos en el juicio, siempre y cuando no pueda imputarse a la parte una negligencia en la tardanza. Lo que muestra confianza en el buen criterio (de garantía) del juez. C. Pechhi. 1973. "Algunas Consideraciones sobre la Preclusión", Revista de Derecho (U. de Concepción). № 160, p. 20.

45 C. Ap. de San Miguel, sentencia de reemplazo de 27 de enero de 2006, consid. $2^{\circ}$, en causa 'Jara Carrasco y otros con Sociedad Inmobiliaria San Francisco Ltda.', rol 1605-2001, (confirmada por la Corte Suprema). La cursiva es mía. 
sentencia. No obstante, sólo operó relativamente, pues dejó abierta la opción de ejercer los medios de defensa en otra etapa procesal, como es la segunda instancia ${ }^{46}$.

En materia de recursos, se puede ver una situación similar en la adhesión a la apelación. La adhesión puede efectuarse en primera instancia hasta que se eleven los autos al grado de revisión. Una vez elevados, entonces precluye relativamente la opción. No obstante, en segunda instancia vuelve a abrirse la facultad desde que se reciben los autos en secretaria hasta finalizado el plazo de la comparecencia, momento en el cual se clausura definitivamente la facultad de adherirse no ejercida (art. 217 CPC en relación con el art. 200 CPC).

iii) La tercera circunstancia es más bien de carácter técnico-teórico. Se trata de la posibilidad de que el Derecho Procesal tenga una apertura retardada o diferida de la preclusión, basado en ciertas razones técnico-jurídicas, para abrir la oportunidad en otro momento procesal. Lo que ocurre aquí es que la oportunidad, y la consiguiente preclusión, son diferidas. Me parece que ello ocurre en ciertas circunstancias en que: (1) por razones de principios procesales, en especial, de economía procesal (en los juicios escritos) o de concentración de actividades (en los orales), o bien de la propia imparcialidad del juzgador (para ambos), (2) la ley restrinja la recursividad a otro tribunal, de ciertas incidencias de suma gravedad para la defensa procesal, (3) y que la sentencia definitiva se haya construido sobre la base de dichas incidencias. (4) Como condición negativa, es necesario que la relatividad de la preclusión no menoscabe el derecho de defensa de la contraria (cláusula de garantía). En dichos casos, se puede atribuir la consecuencia de poder recurrir sobre un vicio en la construcción de dicha sentencia. Observemos que por (1) se desaconseja la partición o dispersión del proceso en esa etapa o momento, pero (2) pesa con su trascendencia para requerir una revisión de la incidencia. Y (3) permite que la conclusión del supuesto vicio en la sentencia definitiva, concrete las razones de (1), pero a su vez, al ser la sentencia misma la que cargue con el grave vicio supuesto, permita concretar (2), insisto sin partir o dividir la tramitación del juicio. a) En materia de proceso escrito, se puede dar en el caso de la no apelación de las resoluciones que conceden ciertas medidas probatorias (por vedarlo el art. 326 inc. 2 CPC), pero que, p.ej., puedan haber sido dictadas con franca violación del procedimiento, pedidas y concedidas ya fuera del término fatal en que debían presentarse, como la lista de testigos o consumida la potestad, como en la solicitud de peritación. En dicho evento, puede permitirse reclamar vía apelación de sentencia definitiva (es decir, de manera indirecta) el vicio antes mencionado. Asimismo, otro tanto ocurre en materia de casación en la forma. Pues, si se interpone la excepción de cosa juzgada in limine litis, de acuerdo al art. 304 CPC, siendo ésta rechazada, y recurrida

46 J.F. Marques señala, en el Derecho brasileño, la situación en que la preclusión que afecta al juez. La refiere a aquella que extingue la posibilidad reexaminar un asunto, pero sólo en lo que atañe al órgano de grado inferior mas no al superior. Instituçoes de Direito Processual Civil, v. II, $3^{\text {a }}$ edic. Forense, Río de Janeiro, 1966, p. 290. 
Sobre preclusiones procesales en el derecho chileno en tiempo de reformas.

Ensayo de una teoría general desde un enfoque valorativo jurídico.

la resolución para preparar el recurso de casación (art. 769 CPC), en segunda instancia también es descartada, entonces no se puede seguir recurriendo, por las razones anotadas (y concretadas en el art. 766 CPC). En tal caso, el último recurso consume la recursividad en principio o relativamente, pero el Derecho Procesal contempla la apertura, de manera diferida, de la oportunidad de recurrir en contra de dicha decisión y comienza a contarse la eventual preclusión por inoportunidad, respecto de la propia sentencia definitiva de segunda instancia que infringió la autoridad de la cosa juzgada alegada in limine, de acuerdo al art. 768 n $^{\circ} 6$ CPC, en los quince días que indica la ley (art. 770 CPC). b) En materia de proceso oral, se puede ver, igualmente, cierto tipo de incidencias penales, como la prescripción de la acción penal, en que si se alega en la audiencia preparatoria (o en otro momento previo) y es rechazada (art. 264- $e$ CPP), no es recurrible a la Corte, pero si alega en el juicio oral e igual suerte corre, entonces sí se lo permite (por errónea aplicación del Derecho en la sentencia, según el art. 373- $b$ CPP en relación con los arts. 94 y ss. CP), pero ello sólo por la regla de concentración. La solución de la preclusión absoluta por consumición, desincentiva el uso de la excepción de previo y especial pronunciamiento, cargando al sistema oral de más juicios, y da un tratamiento desigual en la protección de la ley a varios litigantes que ejercen la misma clase de excepción, en la misma instancia, válidamente desde el punto de vista procesal, pero en momentos procesales diversos (sin perjuicio de la finalidad saneadora de ciertos vicios de la audiencia de preparación). Una situación similar puede verse en materia de exclusiones de prueba ilícita en materia penal. La oportunidad procesal precisa es la audiencia de preparación, según el art. $276 \mathrm{CPP}$, de tal manera que si no se plantea allí, precluye relativamente la opción de reclamar o recurrir, por falta de oportunidad, o bien, si son rechazadas, por consumición. No puede ejercerse este derecho ante el tribunal del juicio oral. No obstante, la ley deja a salvo el recurso de nulidad en contra de la sentencia definitiva que asuma los medios de prueba ilícitos, pues la preclusión relativa es "sin perjuicio de la procedencia, en su caso, del recurso de nulidad en contra de la sentencia definitiva que se dictare en el juicio oral [con prueba ilícita], conforme a las reglas generales", de acuerdo al art. 277 inc. $2 \mathrm{CPP}^{47}$.

3.4.3) En suma, la distinción nos indica que quien debe juzgar debe ser cuidadoso en el

Similar solución a este último caso puede verse en J. López Masle, y M.I. Horvitz, Derecho Procesal Penal Chileno, t. II. Edit. Jurídica de Chile, Santiago, 2004, p. 197 (López atribuye el carácter diferido de la preclusión, a evitar la entrada en conocimiento del contenido de la prueba ilícita del tribunal que debe juzgar sobre el fondo fáctico del asunto y remitir la revisión a otro tribunal). Insistiendo en los ejemplos, agreguemos que cuando ha habido problemas con el debido emplazamiento, y se ha dejado sin notificar a la parte demandada, ésta debe, igualmente, reclamar del vicio en todos sus grados, esto es, en primera y en segunda instancia (si es que existe esta última), y aun cuando no sea acogida la reclamación, la preclusión opera sólo relativamente (y jamás produciendo autoridad de cosa juzgada), quedándole reservado el motivo y el recurso de casación, de acuerdo al art. $795 \mathrm{n}^{\circ} 1$-falta de un trámite esencial- en relación con el art. $768 \mathrm{n}^{\circ} 9 \mathrm{CPC}$-sobre falta del debido emplazamiento. 
enjuiciamiento de la procedencia de la preclusión, pues no basta constatar que ha operado la preclusión, sino que es indispensable que determine qué subclase preclusiva es la que tiene lugar en el caso, dadas sus disímiles consecuencias.

\section{4.- $\quad$ Flexibilidad vs. rigidez}

Como bien señala E. Liebman, en nuestra materia se encuentran enfrentadas: la necesidad de dotar de cierta flexibilidad al proceso, con la de rigidez formal del mismo ${ }^{48}$. Cada tipo de proceso, vgr., sea oral o escrito, por un lado, sea de conocimiento o ejecutivo, por otro, presenta diversas maneras de amalgamar la tensión entre flexibilidad y rigidez. No obstante, existen ciertos aspectos generales sobre los cuales se debe tener cierto cuidado.

4.1.- El mecanismo de la preclusión debe ser tratado con cuidado. En efecto, éste tiende a producir una mayor formalización y rigidez sobre el proceso, quitándole así flexibilidad al mismo. Dado que la preclusión extingue o hace perder una potestad o facultad procesal por ciertas conductas procesales de los sujetos partícipes del proceso, constituye una clara limitación a la variedad de conductas que éstos pueden adoptar.

La idea es que por la acción u omisión de un acto procesal se pierda, precisamente, la facultad de tomar ciertas vías de defensa. Por ende, ella implica también, una limitación a la defensa de los intereses públicos o privados que se puedan ventilar en juicio.

A mayor fuerza preclusiva atribuida a determinados supuestos operativos, mayor restricción de facultades se produce. p.ej., desde el punto de vista cualitativo, una preclusión puede tener menor fuerza, si es que la preclusión de una facultad debe ser denunciada y decretada por el tribunal para que se produzca. Desde el punto de vista cuantitativo, a mayor preclusión, existe una mayor cantidad de actos o medios defensivos que se extinguen o que no es permitido usar y restricción de medios para salvar la preclusión. El clásico ejemplo de ello son las antiguas causales del recurso de casación en materia penal, de acuerdo a la interpretación hiper-restrictiva de la Corte Suprema. Si el recurrente invocaba una causal, como medio de defensa para impugnar una sentencia, entonces la Corte entendía que precluía su facultad para invocar otras causales incompatibles, ni siquiera invocando como medio la tradicional cláusula lingüística "en subsidio" (pero, en una inválida interpretación, además de perder tal facultad específica, si se la invocaba, anulaba todo el acto).

Pero ello no queda sólo en un mero ejercicio artificial, sino que redunda en la limitación de poder llegar a la verdad, dentro de los marcos del proceso, de parte de los intervinientes. Y si 
Sobre preclusiones procesales en el derecho chileno en tiempo de reformas.

Ensayo de una teoría general desde un enfoque valorativo jurídico.

bien es cierto que el rasgo cercenador de la preclusión es importante, lo es también que el sistema de administración de justicia no se puede basar en la adjudicación de una gran cantidad de injusticias sustantivas, basadas en la falsedad de las afirmaciones judiciales, debido casi exclusivamente a las preclusiones, pues terminaría causando graves perjuicios a los ciudadanos y deslegitimándose en el ahora juicio de éstos sobre la judicatura.

Es por lo expuesto que, para no generar una sobreabundancia de preclusiones, que terminen hiper-formalizando el proceso en cualquier etapa, éstas deben ser restringidas estrictamente a sus fines, del correcto orden jurídico procesal, así como del acceso a la tutela jurisdiccional, la prontitud del juzgamiento y la defensa procesal ${ }^{49}$.

4.2.- Como ya vimos, la rigidez de las formas procesales no es un bien absoluto, y debe ser coordinada con una necesaria flexibilidad o elasticidad en la configuración del proceso (que tampoco es absoluta). Ésta tiene un aspecto positivo, pues la correcta tramitación del proceso, en ciertas ocasiones particulares, exige una solución que no deje en la completa indefensión a la parte por causa no imputable a ella.

Así, en materia de procesos orales, la ley procesal penal contempla una norma general como la tutela de garantías (mal llamada "cautela"), mediante la cual el juez puede evitar la preclusión, pudiendo incluso ordenar la suspensión del proceso (art. 10 CPP). Situación similar se da en materia civil de familia, en que el tribunal puede suspender la audiencia por razones

Obsérvese que, al decir de C. Roxin, en Alemania existe una percepción parecida: "Conforme a la jurisprudencia continua del BVerfG [Tribunal Constitucional alemán] no se debe establecer demasiadas exigencias a las precauciones del imputado contra una eventual inobservancia del plazo..., especialmente cuando se trata del plazo para la interposición de una objeción en contra de mandato penal conforme al § 409 (o de una decisión que impone una multa según el $§ 66, \mathrm{OWiG})$, porque en esos casos de 'primer acceso' al tribunal, la objeción representa la única posibilidad para el imputado de obtener el derecho a ser oído...". (Derecho Procesal Penal. Editores del Puerto, trad. G. Córdoba y D. Pastor, B. Aires, 2000, p. 178). La Corte Interamericana de DDHH también restringe al máximo la preclusión, en razón de la naturaleza de las causas sometidas a su decisión. Así puede verse en el caso internacional 'Almonacid Arellano y otros vs. Chile', en donde la Comisión Interamericana, pidió la preclusión de la facultad del Estado de proponer un medio probatorio (perito) y la presentación de ciertos documentos fuera del momento procesal oportuno y, en subsidio, solicitó se garantice el equilibrio procesal, concediendo a las partes una oportunidad para formular observaciones al contenido de los documentos presentados. El Tribunal sentenció que: "La Corte ha señalado anteriormente, en cuanto a la recepción y valoración de la prueba, que los procedimientos que se siguen ante ella no están sujetos a las mismas formalidades que las actuaciones judiciales internas, y que la incorporación de determinados elementos al acervo probatorio debe ser efectuada prestando particular atención a las circunstancias del caso concreto y teniendo presentes los límites trazados por el respeto a la seguridad jurídica y al equilibrio procesal de las partes" (párr. 69). Y agrega: "La Corte nota que parte de la prueba presentada por el Estado junto con sus alegatos finales escritos corresponde a la prueba solicitada por la Corte en la audiencia pública del presente caso (supra párr. 28), por lo cual decide aceptarla. Respecto al resto de la prueba remitida por las partes, este Tribunal igualmente decide admitirla, puesto que la considera útil para la resolución de este caso. Por lo tanto, agrega toda esta documentación al acervo probatorio" (párr. 80). 
de necesidad de una buena tramitación, como cuando no está disponible la prueba relevante decretada por el juez (art. 11 inc. 1 LTF), e inclusive puede salvar la preclusión sobre el acto de contestación de la demanda reconvencional, suspendiendo la audiencia, por motivo fundado (arts. 58 y 11 inc. 2 LTF), como cuando, vgr., el actor reconvencional concurra con su abogado y el demandado reconvencional sólo personalmente (inicialmente autorizado para ello), en razón de la afectación de la defensa técnica ${ }^{50}$. Asimismo, se deja abierta la posibilidad de que el juez de garantía suspenda la audiencia, cuando el imputado no hubiere ofrecido oportunamente medios de prueba, por causas que no le fueren imputables, para efectos precisos de darle la oportunidad para ello (art. 278 CPP). En materia de juicio simplificado, el juez puede evitar la preclusión de la presentación de la evidencia testimonial o pericial en los casos del art. 396 inc. 3 CPP.

Por su parte, en materia de juicios escritos también se puede ver flexibilizaciones. Los inflexibles plazos legales (art. 64 CPC) eventualmente pueden ser detenidos y renovados, por ciertas necesidades de corrección del proceso. En efecto, por la operatividad lógica de las cuestiones de previo y especial pronunciamiento, es posible que introduciendo un incidente de este tipo, estando pendiente el plazo para evacuar cierto trámite, se detenga el plazo y se lo renueve. Cómo señala el art. 87 CPC: "Si el incidente es de aquellos sin cuya previa resolución no se puede seguir substanciando la causa principal, se suspenderá el curso de ésta, y el incidente se tramitará en la misma pieza de autos". Esto se puede ejemplificar en el caso del plazo para contestar, que es detenido y renovado por la interposición de las excepciones dilatorias (art. 305 inc. 1 CPC). Pero esto ocurre sólo por la precedencia lógico-legal de ciertas cuestiones a los trámites que actualmente estén pendientes o se estén llevando a efecto. Al ser de resolución necesariamente previa, el estado de la causa se retrotrae y así también el plazo que estaba corriendo. De ahí que sin importar si se gane o pierda la cuestión, la causa resulte retrotraída; así lo corrobora expresamente la norma del art. 308 CPC. La mencionada facultad tiene límites. En lo pertinente, transcurrido el plazo, éste queda consolidado prima facie y opera la preclusión, por lo que si, luego, se interpone un incidente de previo y especial pronunciamiento, como el de nulidad, éste mero trámite no afectará a la preclusión ni al plazo (sólo en el evento de acogerse la nulidad, pero sólo por el efecto retroactivo de la resolución que decreta la nulidad). Otra situación de flexibilización está en los autos y decretos: no obstante que se produzca la preclusión de los medios normales de impugnación de dichas resoluciones y producirse la "firmeza" y el carácter de ejecutoriada, se deja abierta la posibilidad extraordinaria de recurrir en contra de ellas, si se hacen valer nuevos antecedentes de los que ya obraban en el proceso,

50 Respecto de la contestación de la demanda original, si bien es cierto que se permite la contestación oral en el tribunal mismo (en casos calificados), la ley cuida que dicha contestación e incluso la demanda reconvencional, que debe ser interpuesta conjuntamente con la primera, ocurran dentro del plazo legal, como le ordena al juez el inc. 2 art. 58 LTF. No obstante, cierta práctica judicial entiende que, por la naturaleza de las cuestiones ventiladas, los jueces de familia pueden autorizar, en ciertos casos especiales, a contestar oralmente en la audiencia preparatoria. 
Sobre preclusiones procesales en el derecho chileno en tiempo de reformas.

Ensayo de una teoría general desde un enfoque valorativo jurídico.

según el inc. 1 del art. 181 CPC. Finalmente, podemos ver que incluso en materia de procedimiento ejecutivo -que es más bien stricti iuris- la ley salva la preclusión de alegar incompetencia relativa, cuando el ejecutado se presentó en la gestión preparatoria de la vía, permitiendo invocarla luego, en el plazo de la oposición a la ejecución, según el art. 465 inc. 2 CPC.

No obstante, el extremo negativo de esta cualidad de flexibilidad la vivimos en el viejo procedimiento penal. En la etapa del sumario investigativo, prácticamente no había límites preclusivos temporales a la investigación. A ello se sumaba el bloqueo de la operatividad de la prescripción in limine litis del art. $96 \mathrm{CP}$ (hoy rige el art. 233-a CPP), lo que hacía que la investigación sumarial no tuviera límite alguno previsible. De ahí que se haya sostenido por los expositores del viejo sistema inquisitivo que: "El sumario no está sujeto a plazo y el juez puede prolongarlo hasta donde lo estime conveniente, según el curso de la investigación, sólo termina cuando el juez considera que se han agotado todas las diligencias tendientes a acreditar el hecho punible y se haya determinado la persona del inculpado, aunque debemos dejar en claro que la determinación del delincuente no siempre se logra, y ello no va a significar que la duración del sumario va a ser eterna" ${ }^{51}$. De tales circunstancias es necesario jurídicamente que tanto el legislador como el intérprete deban alejarse.

\section{5.- Etapas en que opera.}

La preclusión procesal puede operar en dos momentos: a) opera en la tramitación de la causa, o $b$ ) después de la sentencia definitiva.

a) Durante la tramitación del proceso. Sea en los procesos escritos, mediante las muy diversas etapas fragmentadas o en los procesos orales, a través de sus audiencias, la preclusión “obra mediante la fijación de un punto hasta el que es posible, y más allá no lo es, introducir nuevos elementos de conocimiento, proponer nuevas peticiones y excepciones" 52 , así como de todos los medios de prueba con que se cuente Así, se da estabilidad al orden jurídico procedimental para llegar a la formal tutela jurisdiccional. En suma, constituye el complemento del impulso procesal, para llegar a la sentencia decisoria.

b) Después de la sentencia definitiva. Este tema podemos enfocarlo desde diversas perspectivas:

- Para las partes, si opera la preclusión (sea por inoportunidad o incompatibilidad o consumición), entonces se extingue la facultad de interponer una impugnación contra

R. Jorquera y P. Herrera, Curso de Derecho Procesal Penal Chileno. La Ley, Santiago, 1993, p. 155.

G. Chiovenda, Instituciones, cit. nota n. 19, v. I, p. 407. 
la sentencia (al menos no una nueva en el caso de la consumición); por lo que ellas no pueden instar a su cambio mediante los mecanismos técnicos destinados al efecto, los recursos (así lo corrobora el art. $174 \mathrm{CPC}$, que supone las operaciones preclusivas) ${ }^{53}$.

- Desde la óptica del juez que dictó la sentencia, usada la jurisdicción y notificada aquélla, se extingue la potestad de alterarla prima facie (art. 182 inc. 1 p. $1^{\text {a }} \mathrm{CPC}$ ).

- Para el resto de la judicatura competente prima facie: $i$. - Si en el proceso rige la norma del principio dispositivo aplicado a los recursos (regla generalísima), entonces precluidos los recursos, se produce la preclusión refleja para la judicatura, en un sólo momento; p.ej., la corte de apelaciones dicta su sentencia y las partes dejan pasar el plazo sin recurrir en contra de ella. Sin embargo, se pueden disociar las preclusiones en diversos momentos. ii.- Existe una variación de la base anterior. En ciertas ocasiones sucede que, aunque algunas partes no interpongan sus recursos, es decir, precluidos para algunos la impugnación, ello no acarree preclusión refleja para la judicatura, en coordenadas de validez personal de la sentencia. El caso se da en algunos muy especiales, como la indivisibilidad (o ciertas situaciones de solidaridad pasiva) ${ }^{54}$, en que si sólo uno de los codeudores recurre en contra de la sentencia, por razones de unidad del objeto enjuiciado, lo que se muta para uno afecta la validez de la sentencia para los otros codeudores (la validez del objeto cambiado, afecta también a las coordenadas personales). En estos casos, la inmutabilidad de la sentencia se produce mediante una preclusión directa sobre los jueces ad quem, cuando se trata del último estadio del orden procesal (previa preclusión por consumición para las partes). iii. - Si se afecta la hipótesis del principio dispositivo, entonces no obstante estar precluidos los recursos en contra de la sentencia, la ley dispone, por razones de política-legislativa, no hacer precluir las potestades de revisión de la judicatura. Se abre el proceso y la competencia para el control de la corrección de la sentencia de primera instancia y, finalmente, poder mutarla si correspondiese. La figura instrumental de tipo oficiosa para aquello es la consulta (ex art. 92 LMC y el art. 533 del viejo CPP). Resuelta la consulta y notificada, para el tribunal revisor se produce la preclusión directamente ${ }^{55}$. De acuerdo a como se ha

53 Ésa es la significación técnica de la preclusión en relación con las resoluciones, en especial, de la preclusión por falta de oportunidad, y no un "conformarse tácitamente" con la resolución, según se creía antaño. Operar una identificación de tal par, implica una confusión y reducción de las maneras en que se produce la preclusión de la "proponibilidad de la impugnación”. E. Liebman señala que la preclusión de las impugnaciones puede producirse por: a) "vencimiento del término" o b) la "aquiescencia" que también puede llamarse "conformidad con el fallo'. La conformidad o aquiescencia puede producirse de manera expresa o tácita, pero la tácita no es el vencimiento del plazo, sino que "resulta de actos incompatibles con la voluntad de valerse de la impugnación" (Manual, cit. nota n. 20, p. 456 y 457).

54 E. Paillas, Recurso de Casación en Materia Civil. Edit. Jurídica de Chile, Santiago, 2008, pp. 170 y 171.

55 Dicho trámite implica su conocimiento previa vista de la causa -aunque no en todo los casos- para el examen oficioso de la Corte. En este caso también se puede examinar -y es interesante hacerlo- la preclusión sobre la partes. Dado que se han perdido las facultades procesales impugnativas, las partes pueden intervenir apoyando los méritos de la sentencia, pidiendo su aprobación. Pero dada la igual protección de la ley, quien no esté 
Sobre preclusiones procesales en el derecho chileno en tiempo de reformas.

Ensayo de una teoría general desde un enfoque valorativo jurídico.

dado nuestra ordenación legal, la consulta de la sentencia puede no ser el último momento procesal de cognición, pues alguna parte podría recurrir en contra de dicha resolución. De ahí que la resolución se volverá inmutable, en el mejor de los casos mediante una preclusión por falta de oportunidad, pero en cualquier caso volviéndose al primer supuesto.

La sumatoria de las preclusiones nos trae el que se produzca la situación jurídica de que la sentencia se vuelva inmutable en el proceso. Pero dicha inmutabilidad no es una institución autónoma, sino sólo el resultado de la preclusión, ambos aplicados al caso particular.

Una vez precluido todo (y, así, inmutable), más ciertos trámites, la sentencia está ejecutoriada para su cumplimiento ${ }^{56}$. Y no obstante la continuación del proceso en su etapa de cumplimiento incidental, sólo se podrán hacer valer contra la sentencia y el juez sólo podrá acoger, en principio, alegaciones de hechos acaecidos con posterioridad a la sentencia firme, según el art. 234 inc. 1 CPC: Otras posibles alegaciones sobre hechos previos, hechas o no valer antes de dicha sentencia precluyen, quedando firme la mentada resolución (salvo, p.ej., art. 234 inc. 4 CPC). En igual sentido, el art. 237 inc. 3 CPC para el juicio ejecutivo.

A su vez, la firmeza preclusiva en esta etapa también tiene importancia para efectos de limitar la revisión de constitucionalidad de la ley, en especial, en el juicio de inaplicabilidad. La sentencia constitucional de inaplicabilidad ordena la no aplicación al caso particular de una norma legal. En los juicios o fases de cognición refiere, técnicamente, a la aplicación de dicha norma en el mérito del fallo judicial. Para tales efectos, es necesario que la gestión judicial esté pendiente, sin aplicación firme o inmutable aún de la norma impugnada (art. 93 nº 6 e inc. 11 CPR). Una vez recaída sentencia judicial inmutable y no obstante que el proceso continúe adelante, p.ej., en etapa de cumplimiento, desde el punto de vista sistemático, la preclusión de las potestades procesales hará que el juez no pueda alterar su sentencia y sus coordenadas de validez (arts. 174 y 234 inc. 1 CPC) y deberá incluso seguir adelante con lo ordenado por ella (sino se afectará alguna coordenada de validez de la sentencia judicial), por lo que no podrá prescindir de la aplicación de ninguna norma legal utilizada. Es por ello que la preclusión

conforme, podría, eventualmente, y dado que la causa está en tabla (con invitación pública a presentar sus observaciones particulares), hacer las observaciones también respecto del demérito de la resolución, para efectos del examen consultivo de la Corte, sin poder, eso sí, hacer ninguna petición concreta. Si consideramos que sólo puede participar quien tiene derecho a hacer peticiones concretas, entonces el que no esté conforme con el fallo y tenga precluida sus facultades petitorias, no podría participar. Una vez ejercido los poderes procesales de resolución de la consulta de manera favorable, entonces quedará firme la sentencia.

56 Me parece que la existencia del art. 174 CPC mira más bien a la preparación del cumplimiento: la ejecutoriedad de la sentencia o que está para ejecutar. Una sentencia pueda estar inmutable o firme de manera previa a alguna de las circunstancias que indica el art. 174, en virtud de la preclusión pro parte o pro iudicato. No obstante, para lograr la certidumbre respecto del momento en que quede lista para la ejecución, establece la ley ciertos trámites conclusivos. 
procesal determina la inmutabilidad o firmeza de la sentencia, marcando el final de la pendencia de una gestión (para los efectos de la aplicación jurídica de esa norma) y limita, consecuencialmente, la potestad de revisión de inaplicabilidad de una norma legal ${ }^{57}$.

Algunos llaman a aquello "la cosa juzgada formal"58. Pero eso implica superponer sobre la entidad de la 'preclusión', en los supuestos en que indicamos, la construcción de otra entidad, que se fundiría con ella. En otras palabras, estaríamos multiplicando entidades sin individualidad, por lo que debe rechazársele por el canon de la navaja de Occam.

Ahora bien, una vez obtenida la última conjunción de preclusiones con la sentencia de terminación, la estabilidad (de ésta) queda sólo protegida al interior del proceso. El problema que surge es el siguiente: ¿qué sucede si el perdidoso, no conforme con el fallo, demanda igual y nuevamente ante otro tribunal? La preclusión, entendida como la venimos tratando, no podrá extender su acción a un ámbito procesal diverso de las impugnaciones y poderes procesales del caso particular. Es allí cuando se necesita una nueva figura, que cubra los espacios que deja la preclusión: la autoridad de la cosa juzgada. Dicha entidad tiene por fin dar estabilidad a la sentencia, frente a posibles acciones o excepciones que tiendan a desconocerla o impugnarla; como dice H. Pereira, "está destinada, por su esencia, a producir efectos fuera del proceso en el ámbito del derecho substancial" ${ }^{59}$. ¿Desde cuándo corre está nueva protección? Obtenida la última preclusión y quedando firme la sentencia al interior del proceso, entonces, y sólo entonces, la ley le atribuye específicamente a aquélla una inmutabilidad especial fuera del proceso, la autoridad de la cosa juzgada, de acuerdo al art. 175 CPC. De tal manera que la preclusión se vuelve un presupuesto para la autoridad de la cosa juzgada.

Como se ve, ambas figuras, la preclusión y la autoridad de la cosa juzgada, cuando miran a la sentencia final, tienen por fin la estabilidad de la solución: la inmutabilidad del mandato. Pero desde la perspectiva de los diversos casos particulares, tanto una inmutabilidad como la otra, tienen un disímil régimen jurídico y una diferente explicación. Una constituye un mero resultado mediante mecanismos procesales, la otra está constituida directamente por una institución que tiene un carácter autónomo del proceso que le da origen (aunque no independiente), precisamente pues busca proyectarse hacia eventuales terceros procesos ${ }^{60}$.

\footnotetext{
57 Respecto de este tema, existen algunas distinciones más que realizar, pero que no son pertinentes a nuestro específico tema.

58 E. Liebman, Manual, cit. nota n. 20, p. 457.

59 H. Pereira, La Cosa Juzgada en el Proceso Civil. Conosur, Santiago, 1997, p. 136.

$60 \quad$ En contra E. Liebman señala que: "La esencia de la cosa juzgada está precisamente en la inmutabilidad de la sentencia, de su contenido y de sus efectos", y agrega que "la distinción entre cosa juzgada formal y cosa juzgada sustancial pierde buena parte de su importancia, y son la una y la otra nada más que inmutabilidad, sus dos caras... La unidad del contenido excluye que sus dos aspectos se pueden escindir y encontrar separados según el objeto de la sentencia" (Manual, cit. nota n. 20, pp. 591 a 593).
} 
Sobre preclusiones procesales en el derecho chileno en tiempo de reformas.

Ensayo de una teoría general desde un enfoque valorativo jurídico.

De acuerdo a lo visto, tenemos, entonces, que todo lo que afecte a la preclusión final, va a alterar al resultado inmutable, y podrá afectar al mandato de la autoridad de la cosa juzgada. Al menos seis son los casos que afectan a la preclusión final:

i.- $\quad$ El de la nulidad de todo lo obrado, por falta de notificación regular, pues como prescribe el art. 234 inc. 4 CPC: "Lo dispuesto en este artículo [sobre oposición al cumplimiento incidental], es sin perjuicio de lo prevenido en el art. 80", e igualmente aunque haya desasimiento prima facie del tribunal al dictar una sentencia, "ello no obsta para que el rebelde haga uso del derecho a que le confiere el art. 80". La posibilidad de afectar derechamente la validez de la sentencia y del resto de los actos y normas del proceso, tiene su ratio legis en la afectación radical a la central garantía de defensa procesal, en cuanto a la posibilidad de conocer y entender la pretensión dirigida en contra del sujeto pasivo.

ii.- La otra posibilidad de alteración viene constituida por el recurso de aclaración, rectificación o enmienda del art. 182 CPC. Su limitación es no alterar el significado de lo resuelto: p.ej., si se debe devolver el lote de A, entonces debe devolverse el lote A, pero no ocurre lo mismo, con el cálculo indemnizatorio final que hubiese resultado al juez, de una sumatoria expresada en la sentencia, cuya cantidad pueda variar. La resolución de este recurso, si bien no necesariamente constituye un todo con el núcleo de lo sentenciado, debido a la constitución compleja de las sentencias ${ }^{61}$, sí debe guardar la coherencia necesaria con aquél, según sea la situación. Como sostiene M. Libedinsky, siguiendo a E. Couture $^{62}$, este recurso tiene tres objetos diferentes: "Aclarar puntos dudosos, esto es con el objeto de explicar el real contenido de la declaración de voluntad manifestada en el fallo, haciendo coincidir lo querido y lo expresado".

"Rectificar errores de copia, de referencia o de cálculos numéricos que aparezcan de manifiesto en la sentencia, o sea, a fin de corregir o enmendar errores materiales que puedan haberse cometido en la sentencia en cuanto documento que da constancia de un acto de voluntad".

61 Esto implica que la resolución, de manera contingente, puede pasar a formar parte de la sentencia impugnada. Así se vio en el caso 'Carlos Agurto y otros con Caja de Previsión de Empleados Particulares', en que la juez acogió una reposición en contra de su resolución "aclaratoria" de la sentencia definitiva, a causa de lo cual, la Corte Suprema decretó: "la juez recurrida no pudo modificar por la vía de la reposición, en la forma en que lo hizo, una resolución [la aclaratoria] que había pasado a formar parte de una sentencia definitiva, por lo que al resolverlo así y la Corte de Apelaciones de Santiago al mantener esa decisión, cometieron falta que debe ser enmendada por esta vía" (sentencia de 6 de agosto de 1986, en recurso de queja, Gaceta Jurídica No 74, 1986, p. 27, la cursiva es mía).

62 M. Libedinsky, "Límites", cit. nota n. 39, p. 4. En igual sentido, en el proceso del trabajo de tipo oral, J. Correa Selamé, Nuevo Procedimiento Laboral. Punto Lex, Santiago, 2006, p. 106. Para el supuesto operativo de que el juez sea quien ejerce ex officio, las facultades de aclaración o enmienda, quedan expresamente restringidas sus facultades, sólo a la posibilidad de rectificar los errores, de acuerdo al art. 184 CPC. 
"Salvar las omisiones, es decir, para llenar vacíos de pronunciamiento, decidiendo peticiones o omitidas o preteridas" y se agrega que "la posibilidad de salvar vacíos de pronunciamiento -no obstante la amplitud del texto de la norma contenida en el art. 182...dejando como única y antieconómica solución, la de casar sentencias por falta de decisión del asunto controvertido..., pugna [además] con el espíritu de preceptos legales como el inciso final del artículo 768 [CPC]"; un caso claro de esto, p.ej, es el no pronunciamiento de costas pedidas. Pero la decisión, siempre debe respetar el principio de coherencia, antes señalado.

iii.- Es aquél que afecta a la incompetencia absoluta. Así, p.ej., una persona no puede ser condenada por un delito, si no es por un tribunal de competencia penal. No obstante estar fallado, por un tribunal civil, aún así puede impugnarse de nulidad el fallo.

$i v$.- Se refiere únicamente al proceso penal. Una vez precluidas todas las opciones de modificación de la sentencia final, la ley de todas maneras deja a salvo una, no importando el tiempo que haya pasado. Si ejecutoriada una sentencia de término condenatoria, se promulga una ley más favorable al condenado (de atenuación o eximición de responsabilidad penal), entonces la ley autoriza a "modificarla de oficio o a petición de parte". Así se puede corroborar en el enunciado del inc. $3^{\circ}$ del art. $18 \mathrm{CP}$. Como indica la norma, esto se realiza de oficio por el propio tribunal -que dictó el fallo de primera instanciao mediante una petición directa del condenado, en el mismo proceso (por lo que no puede calificarse de acción el pedido) ${ }^{63}$.

v.- El tópico de la inobservancia de los presupuestos procesales. Si en el juicio se da la ausencia de uno de los presupuestos procesales, no obstante que no se haya alegado antes de dictada la sentencia de terminación, dicha ausencia va a afectar gravemente a la preclusión final.

La judicatura ha dictaminado sobre nuestro tema en el caso del divorcio 'Quezada Arias con Farías Lauri'. Se trata de que decretado el divorcio por sentencia definitiva aprobada por la Corte, y gestionándose el "cúmplase", se pidió la nulidad procesal por el deceso del actor (acaecido previo a la aprobación de aquélla, pero post sentencia definitiva de primera). La Corte de Apelaciones de Valparaíso, resolvió en apelación, que "la resolución del Tribunal de primer grado que ha señalado que en el presente caso ha operado el desasimiento del Tribunal,

63 Como señala A. Bascuñán, la reforma de la ley 17.772 de 1972 (que reformó el art. 18 CP) sacrificó el principio de la intangibilidad de la sentencia firme en aras de la finalidad garantista de la institución de la retroactividad a favor del condenado, a causa de que la antigua disposición del art. $18 \mathrm{CP}$ implicaba la posibilidad de aplicar una regla que no obstante estuviere promulgada, ella no tuviera vigencia por ser diferida por orden del propio estatuto legal (“Aplicación de Leyes Penales que Carecen de Vigencia”. A. Bascuñan. 2001. Revista del Abogado. $\mathrm{n}^{\mathrm{o}} 22$, http://www.colegioabogados.cl/ [visitada el 28.12.2008]). 
Sobre preclusiones procesales en el derecho chileno en tiempo de reformas. Ensayo de una teoría general desde un enfoque valorativo jurídico.

no se ajusta a derecho". Razona fundándose, en el fondo, en que el divorcio afecta la situación personalísima de los cónyuges. Y, en lo formal, en que "si bien el Tribunal ha dictado el cúmplase, y sin perjuicio de que la subsinscripción no se había efectuado, en realidad no ha operado el referido desasimiento del Tribunal, por cuanto en la especie al haber muerto uno de los contrayentes durante la substanciación del proceso, ha desaparecido uno de los presupuestos de existencia del proceso, cual es la existencia física o legal de las partes. Al respecto la doctrina está conteste que el conflicto jurídico objeto del proceso debe producirse entre las partes y que la ausencia de cualquiera de los presupuestos procesales de existencia -un órgano jurisdiccional, un conflicto de relevancia jurídica y la existencia física o legal de las partes-, trae aparejada la inexistencia del proceso..., en especial, que todas las actuaciones realizadas en el proceso, así como la sentencia, misma, carezcan de valor"64.

vi.- La última es una situación bastante especial, que se da en la sentencia definitiva del Tribunal Constitucional. Terminado el proceso con la sentencia definitiva de única instancia, entonces "no procederá recurso alguno" según dispone tajantemente el art. 94 inc. 1 p. $1^{\text {a }}$ CPR y el art. 32 inc. 1 p. $1^{\text {a }}$ LTC. No obstante, la Constitución y su Ley Orgánica dejan a salvo la facultad del propio Tribunal de poder "modificar" de oficio la resolución, para "rectificar los errores de hecho en que se hubiere incurrido", sin indicación de plazo alguno (las partes $2^{\text {as }}$ de ambos artículos citados $)^{65}$.

\section{6.- Fuentes de los supuestos operativos de la preclusión}

Esta materia se refiere a qué tipo de normas pueden prescribir causales de preclusión que hagan operativa la imputación de la consecuencia de la pérdida del poder procesal. Dependiendo del tipo de régimen en que nos encontremos, el principio de juridicidad procesal identificará un campo de acción más o menos amplio o restrictivo de ciertas clases de normas. Pero ello siempre será respetando la jerarquía normativa.

a) De acuerdo a lo expuesto, el principio de jerarquía normativa implica que sea la Constitución la norma base del ordenamiento nacional a la cual debamos atenernos. Pero junto con ello, podemos encontrar otras normas supremas, aunque extranacionales, que influyen en el terreno nacional, los tratados internacionales en materia de Derechos Humanos, que están amparados por el art. 5 inc. 2 CPR y el art. 27 de la Convención sobre Derecho de los Tratados que prohíbe la excepción de Derecho interno. Ahora bien, por el propio objetivo de este conjunto de normas, es muy difícil encontrar algunas con

64 C. Ap. de Valparaíso, sentencia de 18 de agosto de 2008, redactada por el juez J. Arancibia Pinto, en causa rol 1161-2008. En sentido similar, H. Pereira, cit. nota n. 59, p. 128.

65 Asimismo, la ley le reserva a las partes un recurso de reposición por error de hecho, sometida al plazo de preclusión de siete días (art. 32 inc. 2 LTC). 
una enunciación explícitamente preclusiva. Dada la extrema generalidad de dichas normas, lo que encontramos son garantías que constituyen límites al actuar de las partes y de los jueces, como la del debido proceso del art. $19 \mathrm{n}^{\circ} 3$ inc. 5 CPR, el derecho a ser juzgado en un plazo razonable art. $8 \mathrm{n}^{\circ} 1$ Conv. Americana de DDHH. Como ha mostrado la Corte Suprema, en el caso 'Banco Santander con Recabarren', la correcta comprensión de aquéllas, pasa por el desenvolvimiento y sistematización del rico contenido normativo de las garantías, para producir su armónica y adecuada aplicación al caso particular (supra nota 5).

b) Por su carácter abstracto y menos general que las normas anteriores, es la ley la que da el marco y límite para el resto de las opciones normativas. Según lo visto, en los procesos escritos su intervención es principal, rigiendo en ella un orden máximo legal. Por su parte, en los orales, su intervención está limitada a la fijación de las grandes líneas del decurso procesal, por lo que caracterizamos su intervención como de orden mínimo legal. No obstante, en uno u otro caso, para un mejor desenvolvimiento efectivo del proceso, las normas legales abren o dejan espacios, dentro del principio de la legalidad procesal, para otro tipo de normas.

c) Desde el punto de vista normativista, las resoluciones judiciales también son normas, particulares, y pueden disponer supuestos singulares de la preclusión, como se puede ver en los arts. 67, 68 y el art. 78, todos del CPC. En tal sentido, he señalado en otra ocasión que: "El plazo judicial constituye un precepto normativo de tipo jurídico. Y, por definición, toda norma es regulación de las conductas humanas. Como todo lapso normativo judicial, lo ordenado no es jurídicamente indiferente. Desde el punto de vista lógico, una conducta es indiferente si se pudiese hacer un acto o su negación"66. Sin perjuicio de ello, la concreción de dichas normas requiere de varias matizaciones en relación a su no indiferencia.

d) Pero también pueden tener fuente en las normas negociales de las partes, es decir, los negocios jurídicos procesales. Estos negocios pueden ser de tipo convencional o unilateral.

Los convencionales se pueden ver en materia de árbitros arbitradores y árbitros mixtos (art. $628 \mathrm{CPC}$ ), las normas procedimentales del proceso pueden venir fijadas en todo o parte por lo que se disponga en el compromiso constitutivo, según el art. 636 inc. 1 CPC.

En nuestros procesos orales, dada la relativa desformalización, la decisión del orden de

66 E. Gandulfo, "El Plazo Judicial para Formalizar y el Mecanismo Normativo de la Sobre-Protección", en Delito Pena y Proceso, (L. Rodríguez, coord.). Edit. Jurídica de Chile, Santiago, 2008, p. 791. 
Sobre preclusiones procesales en el derecho chileno en tiempo de reformas.

Ensayo de una teoría general desde un enfoque valorativo jurídico.

las pruebas es individual: el régimen lo pone cada parte. i.- La Ley de Tribunales de Familia, por encima del poder directivo del juez, dispone que el orden con que se emita y reciba la prueba -entiéndase cada conjunto de pruebas-, quedará sometido a la estrategia defensiva de cada parte: "La prueba se rendirá de acuerdo al orden que fijen las partes" (art. 64 inc. $1 \mathrm{LTF}$ ), es decir, podrán determinar si se recibe la documental primero y luego la declaración de los testigos, o primero la declaración de parte y luego el resto, etc; es una decisión soberana de cada parte en la que el juez no puede entrometerse mayormente. ii.- En materia penal, la decisión sobre el orden de presentación es estrictamente individual, según el art. 328 CPP. iii.- Rompe el canon de desformalización el proceso laboral, que malamente sí dispone un orden legal en este tópico (art. $454 \mathrm{n}^{\circ} 1$ inc. $3 \mathrm{CdT}$ ). En las dos primeras clases de casos, este orden autónomo tiene ciertos marcos formales, en el sentido de que primero corresponde al sujeto activo, el demandante o acusador, $y$, finalmente, al sujeto pasivo, el demandado o acusado. En los laborales, marca la excepción el caso de los juicios de despido, en que es el demandado el que debe rendir primero su prueba (para acreditar los hechos alegados en la comunicación de despido), según el art. 454 no 1 inc. $2 \mathrm{CdT}^{67}$.

Lo importante está en que, pasado dichos términos, la facultad de presentar la evidencia precluye, y no se podrá incorporar, p.ej., la documental (salvo reserva aceptada por el tribunal).

e) Los autoacordados de la Corte Suprema. Aunque los casos más importantes establecen un proceso más bien discrecional, se puede ver, p.ej., en el relativo al proceso constitucional de protección, estableciendo regla de preclusión. Así, el art. 6 inc. 2 de dicho AA prescribe un plazo preclusivo del tipo fatal, de 5 días para apelar de la sentencia definitiva. Si es interpuesto fuera de plazo deberá ser declarado inadmisible por el propio Tribunal $a$ quo ${ }^{68}$.

f) Por los principios jurídicos, técnicamente reconstruidos por la teoría jurídica (y por teoría me refiero a cualquier actividad teórica inclusive la contenida en las sentencias). Tanto la reconstrucción del debido proceso, como del principio de defensa y de la certeza jurídica, confluyen a la formación de la preclusión procesal. Ésta puede ser enfocada desde diversas perspectivas, ninguna menos valiosa que la otra. Así, puede entenderse como una norma de principio por su apertura o puede ser enfocada como un mecanismo procesal, en base

67 La ratio de esta excepción radica en la ligazón que establece la ley del trabajo entre la demanda, la contestación y el acto formal de comunicación del despido. Este último, con su rasgo formalista, fija las expectativas procesales, previo al juicio, que se van a ventilar en la demanda. De esta manera, el legislador hace partir la cuestión con ribetes procesales desde un estadio anterior a la propia demanda con la ligazón al acto de comunicación del despido (vid. F. Tapia et al., Manual de Juicio del Trabajo, Academia Judicial, Santiago, 2008, p. 87).

68 H. Nogueira. 2007. "El Recurso de Protección en el Contexto del Amparo de los Derechos Fundamentales Latinoamericano e Interamericano", Ius et Praxis No 1, año 13, p. 121. 
a la operatividad o como una institución o figura, que parte de cierta hipótesis inicial. Lo importante es que en el Derecho y, en especial, el Derecho Procesal, la enorme construcción de la teoría sobrepasa con creces la legislación procesal (lo que es una normal consecuencia de la técnica del macroproyecto Codificador). Tal situación se puede corroborar en la práctica judicial, a todo nivel, en que se echa mano de diversas reconstrucciones de todo tipo (desde la economía procesal, el acto propio, la buena fe, el fraude procesal, etc.), para derechamente regular la actividad procesal. Partiendo desde el principio del debido proceso, de la inviolabilidad de la defensa procesal, llegando hasta la propia preclusión procesal, así se ha generado una poderosa construcción teórica de estos principios, trasformándose en verdaderas instituciones jurídicas, mediante el desarrollo de sus hipótesis base, contando con la indispensable corroboración lógica directa e indirecta en los enunciados legales, constitucionales e internacionales, para efectos de ganarse la calificación de institución normativa. Una de las cosas más importantes para su aplicación práctica, aparte de la ya vista, radica en la precisión que tenga la institución. En tal sentido, el desarrollo del principio de la institución debe ser tal que permita la previsión de la aplicación práctica que tenga en los casos particulares ${ }^{69}$. Asimismo, el control de tal aplicación se debe reconducir a los valores jurídicos que pretende proteger el mencionado desarrollo, así como la articulación con otros valores e instituciones apreciados por la comunidad jurídica.

Precisamente, uno de dichos principios e institución reconstruida por los juristas y jueces es la preclusión procesal. Si se fija bien el lector, el legislador de la Codificación no siempre plasma completamente toda una idea, sino que a veces lo hace fraccionadamente, y espera que, dada la técnica metodológica de la Codificación basada en la sistemática, pueda el jurista y el juez lograr reconstrucciones que abarquen esa legislación fragmentaria. La preclusión procesal, en especial, los casos en que se atribuye por incompatibilidad y por consumición, en general vienen regulados en ciertos casos, fragmentarios, en el mejor de los casos, pero no en todos, por lo que la práctica hace aplicación de nuestra institución preclusiva, para lograr satisfacer las necesidades procesales que surgen en estos casos, en base a la reconstrucción de los teóricos en cuanto a sus causales.

En suma, dada la pluralidad de concurrencias normativas, más que tratarse de un orden legal consecutivo lo protegido de manera inmediata por nuestro mecanismo, se apunta a algo más amplio: a un orden jurídico consecutivo de los actos procesales, mediante una pluralidad de fuentes jurídicas más que legales.

Véase mi crítica a la aplicación poco técnica de un principio (el del acto propio) por la Corte Suprema, y su contribución al vulgarismo jurídico, en E. Gandulfo, "La Aplicación", cit. nota n. 13, pp. 363 a 365 . Por el contrario, respecto de una aplicación técnicamente correcta de los principios, vid. E. Gandulfo. 2008. "Casación y Constitución, en Materia Civil de Fondo. Reflexiones Metodológicas sobre una Sentencia que Venció las Tentaciones", Ius et Praxis No 14, año 2, pp. 611-637. 


\section{7.- Tipos de supuestos operativos de preclusión}

Frente a las necesidades que generaban los valores jurídicos que vimos al principio, surge el orden consecutivo, sea temporal o lógico-pragmático. Pues bien, los supuestos operativos a los cuales se atribuyen preclusiones procesales, son expresiones de protección de este orden consecutivo. La cuestión temporal se refiere a que los actos se realicen, sólo dentro de una cierta oportunidad, mientras que la cuestión lógico-pragmática mira a que exista una cierta disposición formal en una conjunción entre dos o más medios. Existen tres clases de supuestos, cuya construcción específica gira en torno a tres criterios: tiempo, compatibilidad y consumo, lo que da origen a:

a) Preclusión por falta de oportunidad;

b) Preclusión por incompatibilidad;

c) Preclusión por consumición.

A) Preclusión por Falta de Oportunidad. En estos supuestos el criterio base es el tiempo. El posible acto o las diligencias de investigación que debieron realizarse dentro de cierto tiempo y que no fueron realizadas en él, ya no pueden realizarse.

Ahora bien, el tiempo es tratado por el Derecho desde el punto de vista normativo. Esto significa que cualquier plazo o término que se disponga para ser cumplido por las partes de un proceso, siempre es normativo. Así, si rige el principio dispositivo, el cumplimiento de la norma podrá tener un carácter de carga, afectando sólo al interés de la parte. Por su parte, es claro que, en general, quien goza del derecho de defensa, no tiene, técnicamente, una obligación o necesidad jurídica de cumplirla (A. de la Oliva ${ }^{70}$ ). No obstante, en sentido amplísimo, puede considerarse un deber ser. Así, si no se realiza algo en cierta oportunidad, entonces se debe imputar la pérdida de la facultad procesal de realizar determinado acto.

A.1.- Ésta puede dividirse en dos subtipos: por falta de realización del acto procesal dentro de un cierto plazo o en un cierto término.

A.1.1.- La falta de realización dentro de un cierto plazo, se refiere a la situación en que el sujeto procesal no realiza el acto, dentro de un período de tiempo o conjunto de momentos, en el cual aquél podía y debía realizarlo. Este subtipo de supuestos es el dominante en los "procesos escritos" técnicamente definidos. El ordenamiento de estos procesos se construye en torno a la división en períodos de tiempo ${ }^{71}$. En los procesos civiles tradicionales, los actos escritos deben

Vid. A. Carocca, Manual, cit. nota n. 24, p. 44. 
ser presentados y firmados en el plazo dispuesto legalmente ${ }^{72}$. Asimismo, todas las diligencias de prueba deben solicitarse dentro de un cierto período o lapso y, en ciertos casos, realizarse dentro de él, como la declaración de testigos (art. 340 CPC). Este lapso es de 20 días en el juicio ordinario de mayor cuantía, de 8 días en los incidentes y en el juicio sumario y de menor cuantía, según nuestro viejo CPC. La fase de discusión también se divide en plazos, como la contestación, 15 días desde la notificación y 6 días para la réplica y la dúplica, en el juicio ordinario de mayor cuantía.

En ciertas ocasiones, la preclusión del plazo viene marcada por un específico momento, desde el cual ya no se podrá ejecutar el acto. Un ejemplo viene dado por la oportunidad para pedir la reducción del embargo (art. 447 p. $2^{\text {a }}$ CPC). La Corte de Apelaciones de Talca, en el caso 'Zapata Mora y otros con Olivos Marchant', decretó que "el ejecutado, antes de la fecha fijada para el remate del 17 de octubre de 2005, esto es, el 14 de dicho mes y año, solicitó reducción del embargo", y que "en la especie, entonces, no puede sostenerse que ha operado el principio de la preclusión procesal, pues el ejecutado solicitó oportunamente la reducción del embargo trabado sobre el bien raíz"73.

Pero no se crea que los plazos sean propios de los procesos escritos. Los recursos procesales, en todo tipo de procesos, tienen la tendencia a ser construidos con base en plazos, precisamente, para dar un tiempo fijo de estudio a la formalización de los mismos, en tanto se exige que los

72 Así lo ha resuelto la Corte de Apelaciones de Concepción, en el caso 'Maldonado Chaparro con SII', sentencia de 5 de septiembre de 2005, rol 1505-2000, por un recurso de apelación no firmado: "3.- Que el profesor de Derecho Procesal don Julio Salas Vivaldi, en su artículo sobre los escritos y su firma, opina 'que la firma de la parte de quien dice que emana es un requisito indispensable para la existencia de todo escrito, ya que de otra manera no podría establecerse la identidad de su autor. Sostener lo contrario atenta respecto de la certeza exigida por la ley dentro del proceso judicial, ya que perfectamente extraños a él podrían deducir recursos y formular peticiones, aunque no estuvieren habilitados para ello, bastando simplemente que, posteriormente, incluso expirados los plazos, si lo estiman conveniente, fueran firmados por la parte o su apoderado. En estas situaciones se podrían vulnerar fácilmente los plazos, especialmente si son de carácter fatal, como los prescritos en el Código Procedimiento Civil'. Agrega que 'la firma de la parte o de su apoderado, es un requisito indispensable de todo escrito, constituyendo el elemento identificatorio elemental que garantiza la seriedad del desarrollo regular del proceso. Sólo cuando ella es estampada la respectiva presentación adquiere validez y está en condiciones de producir los efectos deseados por su autor, siempre, naturalmente, que lo sea dentro de los plazos pertinentes, como lo requiere el principio de la preclusión".

“4.- Que, esta posición ha sido recogida por esta Corte en fallos de 10 de junio de 1992 y de 15 de marzo de 1993 (Ministros Tapia, Aqueveque e integrante Sáez y Ministros Tapia, Espinosa y Vásquez) y por la Excma. Corte Suprema de Justicia en fallo de 24 de agosto de 1987 publicada en Fallos de Mes N 345, página 474”.

"5.- Que, el autor Carlos Anabalón Sanderson [...] señala que 'Respecto de la firma puesta al pie de un escrito, como se comprende, ella es la manifestación de que el firmante hace suyo y responde del contenido de la solicitud. Además, como requisito indispensable para la validez del escrito, la firma debe ser puesta en la debida oportunidad, y, por consiguiente, no se cumple con el trámite o la actuación correspondiente si el escrito aparece firmado después de expirado el plazo que la ley señale al efecto".

73 C. Ap. de Talca, sentencia de 2 de mayo de 2006, rol 5-2006, en materia laboral, redacción del juez E. Meins. 
Sobre preclusiones procesales en el derecho chileno en tiempo de reformas. Ensayo de una teoría general desde un enfoque valorativo jurídico.

recursos sean fundados en su interposición. p.ej., la reposición 5 días (art. 181 inc. 2 CPC), la apelación 10 y 5 días (art. 189 CPC), la casación 15 días (art. 770 CPC); a dichas normas se remite la Ley de Tribunales de Familia, según su art. 67 -salvo en materia de reposición según se verá (similar solución da el art. 474 CdT). En el proceso penal, la reposición debe interponerse dentro de $3^{\circ}$ día de manera fundada (art. $362 \mathrm{CPP}$ ), la apelación dentro del $5^{\circ}$ día también fundada (art. $366 \mathrm{CPP}$ ), y la nulidad dentro del $10^{\circ}$ día (art. $372 \mathrm{CPP}$ ). Además, deben contabilizarse los plazos legales del art. 247 CPP y los judiciales que facultan los arts. 186 y $234 \mathrm{CPP}$, impuestos sobre la actividad de los fiscales. En el proceso oral del trabajo el recurso de unificación de jurisprudencia, en contra de una sentencia de recurso de nulidad, puede interponerse dentro del plazo de 15 días (art. 483-A CdT). Finalmente, la importante actividad de la contestación y reconvención en el proceso ordinario de familia y del trabajo, debe realizarse, por escrito, con al menos 5 días de anticipación a la fecha de realización de la audiencia preparatoria (art. 58 inc. 1 LTF y art. 452 CdT).

A.1.2.- La falta de realización de un acto procesal también puede ocurrir, porque pudo y debió ser efectuado en un cierto término. En este caso, los sujetos no tienen un conjunto de momentos. Sólo se cuenta con un momento específico y preciso de realización, fuera de esa ocasión se produce la preclusión y ya no puede realizarse el acto con valor jurídico. Según M. Fenech, el momento es fijado en una medida del tiempo -p.ej., como un día específico-, o mediante la designación de un determinado acontecimiento futuro y cierto, positivo o negativo ${ }^{74}$ -p.ej., como la audiencia preparatoria. En este sentido apuntado, el término es visto más bien como una unidad temporal, sin perjuicio de que el Derecho pueda separarlo en subunidades para específicos efectos.

¿Hasta cuándo se puede realizar un acto o, en otros palabras, cuándo precluye la opción? Esta pregunta es la que quizá cueste más asumir a la práctica de los jueces. De acuerdo a la coherencia con la definición anterior, debemos decir que ella puede realizarse en cualquier tiempo de la unidad temporal que constituye el término (siendo indiferente si es al principio o al final). Así, p.ej., si alguien está citado a una audiencia que comienza a las 12:00 hrs., puede incorporarse en el término o unidad en cualquier tiempo, hasta que se dé por cerrado dicho término, asumiendo lo obrado ya en el proceso. Pero ello implica trasladar el punto de examen, a la forma de entender y articular los términos en los tipos de procesos.

En los procesos orales es donde se halla la tendencia más marcada hacia los términos. Ello se debe a que en su construcción prima el principio de concentración de las actividades procesales en ciertos momentos: las audiencias típicas, en las cuales se ventila la eventual discusión y la probanza, incluyendo el fallo mismo. ¿Hasta cuándo se puede realizar en Derecho

74 M. Fenech, Derecho Procesal Penal, v. I, $3^{\text {a }}$ edic. Edit. Labor, Barcelona, 1960, p. 495. 
la opción o facultad sin que precluya? Ello depende de cómo se enfoquen los términos del proceso oral por el Derecho. Existen dos grandes términos: la audiencia de preparación y la del juicio oral mismo. a) Internamente en la audiencia, en coherencia con su carácter de término, rige la norma de continuación de la audiencia (art. 282 CPP, art. 11 LTF y art. 426 in. 3 CdT), es decir, como un único momento, lo que limita la preclusión por inoportunidad. No obstante, el Derecho puede separar esta unidad para determinados efectos, para así proteger el correcto orden especialmente cargado por el derecho de defensa que está de trasfondo. Ej. La ley procesal manda expresamente que la acumulación o desacumulación de pretensiones, "procederán sólo hasta el inicio de la audiencia preparatoria" (art. 17 p. $2^{\mathrm{a}}$ LTF). Lo que sí debe tenerse presente, es que en razón de la dirección de oficio de las audiencias, éstas se vuelven mucho más flexibles, pero ni ésta ni la economía procesal pueden ser título para dejar en indefensión procesal a alguna de las partes del proceso. $b$ ) Entre audiencias, estamos tratando, entonces, de dos términos separados, por lo que puede operar la preclusión entre un término y otro. P.ej., según ha decretado la Corte Suprema, en el caso 'Ministerio público con Chuica Lebien y Santana Barra', de la pluma del juez N. Segura, "es la audiencia de preparación del juicio la oportunidad que tienen las partes para discutir y excluir las pruebas que hubiesen propuesto; las aceptadas deben ser recibidas en el juicio oral y durante él no es posible discutir ni aceptar nuevas exclusiones por evidente preclusión de este derecho para las partes y no autorizarlo las normas que rigen esta etapa procesal"75 (ello sin perjuicio de los espacios de flexibilidad que establece la ley según vimos).

En los procedimientos escritos, también hay casos de términos, la absolución de posiciones de los juicios escritos, p.ej., sólo puede ser realizada en el comparendo especialmente ordenado. Lo mismo ocurre con la citación a declarar de los testigos, en que el tribunal, usualmente, fija dos días para ello; lo tradicional es que sean los dos últimos días del probatorio.

A.2.- No se debe asumir que la ley sólo pueda disponer un régimen unívoco: o bien un plazo o bien un término, para una misma figura. Existen ciertos casos en que la ley contempla un régimen mixto para una figura, produciéndose la preclusión de manera alternativa. Así, p.ej., el art. 67 n 1 LTF dispone que el recurso de reposición procede dentro del plazo de 3 días desde la notificación. Pero la regla se ve alterada si hay una audiencia fijada en menor plazo, pues, en tal caso, la ley dispone el término de interposición, de la misma audiencia.

A.3.- El tratamiento en principio unitario de régimen para plazos y términos, se basa en que la ley chilena no realiza una distinción exhaustiva en materia de preclusión. La ley procesal dispone una regulación sobre el tema del tiempo, de manera relativamente unitaria, en el sentido de que: sea un período de tiempo o un momento específico, se establece la misma consecuencia. Así, p.ej., tanto los arts. 64 y 65 CPC, enuncian indistintamente de plazos y términos, como los 
Sobre preclusiones procesales en el derecho chileno en tiempo de reformas.

Ensayo de una teoría general desde un enfoque valorativo jurídico.

arts. 14, 15 y 16 CPP, regulan como una sola situación ambos supuestos fácticos bajo la idea de "plazos".

No obstante, debe hacerse presente que la práctica de los procesos escritos da un tratamiento desigual a los plazos y términos judiciales, según veremos en A.5.

A.4.- Ambas expresiones pueden dar pie para que se produzca, lo que se denomina la “acumulación eventual" o "principio de eventualidad". V. Fairén, explicando esto, señala que "cuando se abre una 'oportunidad legal' para las partes..., dicha parte debe aprovecharla para exponer toda su argumentación o proponer todas las pruebas, sin poder esperar que el juez rechace un argumento o fundamento para esgrimir otro, o que un medio de prueba tenga consecuencias desfavorables, para practicar otro"76 . Agrega P. Calamandrei, que la parte debe acumular todos los medios o alegaciones, aun cuando alguno de los mismos, no esté destinado a ser usado, sino en la eventualidad de que los propuestos, por vía principal, no sean aceptados, es decir, las partes deben estar preparadas anticipadamente en previsión de toda eventualidad ${ }^{77}$.

En el caso de los procesos orales se entiende, desde el punto de vista técnico, que no se produce necesariamente la acumulación eventual, pues el juez puede, con sus facultades de dirección, ordenar que se traten las acciones o excepciones por separado, en las audiencias, no obstante la idea de acumulación procesal. En nuestro Derecho, especialmente puede ocurrir ello en el caso de las excepciones dilatorias o de previo y especial pronunciamiento, ordenando el juez que las evacue de a uno. Para evitar que se entrabe el proceso, en la teoría se prevén normas de sanción al litigante dilatorio, y los poderes directivos del juez que pueden impedir in limine litis dichas presentaciones (A. Wach) ${ }^{78}$. Tal facultad debe administrarse con mucha cautela y tomando los resguardos para la protección del derecho de defensa, pues como bien saben los abogados litigantes, la separación muchas veces sirve para esconder ciertos materiales, encajonar a la contraria y frustrar su estrategia; de ahí que la posible división del debate de

76 V. Fairén, Teoría, cita nota n. 22, p. 409. En sentido similar J. Montero Aroca, "Síntesis”, cit. nota n. 24, p. 669 y A. Carocca, Manual, cit. nota n. 24, p. 45. La Corte de Apelaciones de San Miguel, en 'Soto Miranda y otros con Levera Service S.A y otras', materia laboral, ha seguido tal dirección teórica, al sentenciar de manera firme (respecto de la defensa alegada, luego de tramitado buena parte del proceso, de que debió haberse notificado a los herederos del fallecido dueño de las empresas demandadas), que "en la especie operó el principio de la preclusión, que obligaba a la representante de las empresas a hacer valer sus alegaciones en la oportunidad procesal correspondiente, esto es, bajo lo señalado por el también llamado principio de la eventualidad, que exige que los actos jurídicos procesales se ejerzan en cada una de las oportunidades señaladas por la ley y, en caso contrario, habrá precluido dicho derecho" (sentencia de 12 de junio de 2007, rol 517-2006 Tr., redactada por la juez A.M. Arratia).

77 P. Calamandrei, Instituciones, cit. nota n. 15, p. 391.

78 A. Wach, Conferencias, cit. nota n. 28, pp. 40 a 42 y 45 a 47. 
Eduardo Gandulfo R.

fondo deba realizarse, con previo conocimiento de todas las deducciones y excepciones, tanto en materia civil como penal ${ }^{79}$.

A.5.- Como ya se ha señalado, en esta materia la fuerza preclusiva de las normas sobre el tiempo son diferentes, en especial en materia civil y las normas que se remitan al Código de Procedimiento Civil:

i) Si se ha prescrito un momento o lapso mediante una norma de tipo legal, en el ámbito del CPC, su art. 64 dispone la pérdida inmediata y automática de la facultad procesal no ejercida: "Los plazos que señala este Código son fatales cualquiera sea la forma en que se exprese... En consecuencia, la posibilidad de ejercer un derecho o la oportunidad para ejecutar el acto se extingue al vencimiento del plazo. En estos casos el tribunal, de oficio o a petición de parte, proveerá lo que convenga para la prosecución del juicio sin necesidad de certificado previo". Lo mismo ocurre, en materia penal, en el art. 16 CPP: "Los plazos establecidos en este Código son fatales e improrrogables, a menos que se indicare expresamente lo contrario"; y en el área laboral, de acuerdo al art. 435 CdT.

ii) Si la norma que prescribe el plazo en el ámbito del CPC, es una de carácter judicial, el no ejercicio dentro del tiempo establecido, no hace precluir la facultad de manera inmediata y automática. El Derecho contempla la necesidad de decretar el incumplimiento y es otra cosa, la resolución del tribunal, la que constituye la pérdida de la facultad procesal de acuerdo al art. 78 CPC: "Vencido un plazo judicial para realización de un acto procesal sin que éste se haya practicado por la parte respectiva, el tribunal, de oficio o a petición de parte, declarará evacuado dicho trámite en su rebeldía y proveerá lo que convenga para la prosecución del juicio, sin certificado previo del secretario"; como señalaba F. Alessandri, declarada la rebeldía, su efecto es dar por evacuado el trámite que no se ejecutó ${ }^{80}$.

79 Es necesario rescatar, especialmente, el contenido del argumento puesto por el Tribunal Europeo de DDHH, en el caso 'Pélissier y Sassi vs. Francia', en que señala que el "derecho a ser informado sobre la naturaleza y la causa de la acusación debe ser considerada a la luz del derecho del imputado de preparar su defensa", y se agrega: "La Corte considera que, en cuestiones penales, el precepto concerniente a una información completa y detallada de los cargos formulados contra el imputado y, consecuentemente, a la calificación legal que el tribunal pueda adoptar al respecto, constituye un prerrequisito esencial para asegurar que los procedimientos sean justos". Por su parte, en materia procesal civil, J. Montero Aroca, enjuiciando críticamente la CPO alemana, indica que el error en que incurrió ésta en 1877, fue que "no previó... sistemas para lograr que las partes fueran a la audiencia con pleno conocimiento de las cuestiones que iban a ser discutidas" (Derecho, cit. nota n. 23, t. I, p. 526).

80 F. Alessandrí, Reglas, cit. nota n. 43, p. 43. M. Otero da cuenta sobre el origen de la redacción del artículo, señalando que la "rebeldía sólo tiene cabida en el caso de los plazos no fatales, por cuanto es la única forma que establece el Código para que opere la preclusión y pueda continuar el curso progresivo" (Derecho, cit. nota n. 40, p. 83). 
Sobre preclusiones procesales en el derecho chileno en tiempo de reformas.

Ensayo de una teoría general desde un enfoque valorativo jurídico.

iii) Los términos judiciales en materia de procesos escritos bajo la égida del principio dispositivo tienen una solución diversa. P.ej., el de la declaración en absolución de posiciones, requiere que el acto sea realizado dentro de los días que señala el tribunal, y se haga en el preciso momento horario que éste dispone, al menos su llamado, salvo acuerdo de las partes. La razón para ello estriba en que dicha clase de términos, imponen un momento preciso para la práctica del acto, no hay más día habilitado para cumplir, y dado que se trata de días precisos y accidentales, que pueden ser cualquiera, incluso separados, entonces el término no operará como el plazo, como para decir que la facultad puede seguir vigente, pues no hay determinación de qué día seguirá siendo el habilitado. A más, súmese que ellos, como en el caso de la deposición de los testigos o la absolución de posiciones, importan una actividad bilateral, cuya extensión horaria o diaria implicaría dejar a la contraria pendiente todos los días y horas en que pudiese llevarse a efecto. Para salvar la rigidez del término, y sin que exista acuerdo de las partes, sólo queda alegar el entorpecimiento para evitar la preclusión absoluta y pedir nuevo día juntamente.

iv) En los procesos orales, los términos judiciales prácticamente se confunden con la tramitación misma del proceso, por lo que deben ser observados desde y dentro de la teoría del proceso oral.

A.6.- Los términos y plazos, en vistas a la preclusión, son puestos para el mayor orden temporal del proceso y certeza jurídica. Así, permiten que el proceso se vaya desenvolviendo en etapas o tiempos, sea que éste se halle fraccionado o bien concentrado en audiencia.

a) De esta manera, permiten que los procesos no se eternicen o sean indefinidos, quedándose estancado el proceso en alguna etapa o subfase. Así, p.ej., el plazo preclusivo para contestar la demanda permite pasar luego a la contestación, y el plazo puesto a ésta permite pasar a la réplica y, luego, la dúplica, en el procedimiento escrito ordinario de mayor cuantía. Por su parte, en los procedimientos orales, el momento de demandar precede y permite pasar al de la contestación, y en la audiencia preliminar, luego de expuestas las cartas y recibida a prueba la causa, se procede a la fase de ofrecimiento de medios. Los derechos y excepciones que no se hayan hecho valer en el plazo o momento oportuno, y estando sometidos a preclusión absoluta, se pierden absolutamente y no pueden ser parte del enjuiciamiento, por lo que no puede haber retroceso o vuelta a discutir cuestiones no planteadas en el momento procesal oportuno. En suma, no se puede reabrir el debate o proceso sobre cuestiones pasadas y no planteadas (prohibición de enmendatio libelli). Asimismo, se ve que mediante estos plazos y términos preclusivos la fase de discusión y la eventual discusión tendrán un límite de certidumbre; y lo mismo ocurre con la investigación probatoria y la investigación fiscal, ningún partícipe de los procesos puede eternizarse o gozar de una investigación absolutamente indefinida.

La compleja estructura procesal, acorde con la igualmente compleja realidad de los juicios 
penales, no sólo protege frente a dicha eternización o indefinición, sino que también resguarda frente a ciertas situaciones en donde sus bienes jurídicos potencialmente afectados por el proceso, son puestos en juego de manera más directa por la investigación punitiva. Es por aquello, que el Legislador puede hacer combinaciones de tipos de plazos preclusivos a efectos de la mayor protección, como son los plazos judiciales preclusivos (arts. 186 y 234 CPP) junto a los lapsos legales de preclusión y de prescripción (arts. 233$a, b$ y $247 \mathrm{CPP})$.

En suma, se ve en estos casos, con claridad, la sucesión de actos procesales impulsados y asegurados en su paso o avance por la preclusión por falta de oportunidad.

b) Desde otra perspectiva, la preclusión produce un efecto de saneo del proceso, en vistas a obtener una sentencia definitiva limpia. En efecto, mediante la preclusión se extinguen las opciones de hacer valer los vicios de las nulidades que afecten al proceso y que, eventualmente, por el principio de extensión, pudiesen rebotar en la sentencia definitiva. "Toda nulidad queda subsanada si la parte perjudicada no reclama del vicio oportunamente" (art. 25 inc. 4 LTF), y las "nulidades quedarán subsanadas si el interviniente en el procedimiento perjudicado no impetrare su declaración oportunamente" (art. 164 CPP). De esta guisa, en caso de un eventual recurso en contra de la sentencia definitiva, por el efecto de saneo, la respectiva Corte deberá considerar saneado el vicio para todos los efectos legales (todo ello salvo las causales de nulidad absoluta insaneables según el art. $160 \mathrm{CPP}$ en relación con el art. $374 \mathrm{CPP}^{81}$ ).

c) Pero, además, con estos términos y plazos preclusivos en relación con los actos base de la discusión, al precluir los derechos y excepciones no hechas valer, se le da precisión a la discusión -permitiéndose construir la congruencia procesal-, y dota a las partes de la estabilidad suficiente para la que desee debatir y preparar una estrategia de defensa, sin sorpresas ilegítimas. En efecto, veda, en general, el escenario estratégico en que se le pone a una parte de tener que defender una determinada posición jurídica, que suponga desacreditar la de la contraria y que en tal acción defensiva, se implique entregar medios que acrediten una tesis jurídica "fantasma" favorable a la contraria, la cual no ha formulado en el proceso, pero que espera plantear, para que inclusive le afecte el acto propio al litigante y no pueda desligarse de algo presentado por él mismo pero que no pudo planear evitar por la ausencia, hasta el momento, de esta otra tesis fantasma.

No debe incurrirse en el error de confundir la nulidad absoluta con la nulidad de Derecho Público. Todas las nulidades procesales son originadas por infracción al Derecho Público, de cualquier nivel o especie de éste, por lo que todas las nulidades procesales son de Derecho Público. La importancia real para los procesalistas está en la trascendencia que tenga el vicio, en relación con las consecuencias normativas que se le atribuyan, y no simplemente pertenecer a la macro-categoría de "nulidad de Derecho Público". 
Sobre preclusiones procesales en el derecho chileno en tiempo de reformas.

Ensayo de una teoría general desde un enfoque valorativo jurídico.

B) Preclusión por Incompatibilidad.- Debemos recordar que la preclusión busca disciplinar el posible apartamiento de la conducta de los sujetos procesales respecto del correcto orden consecutivo, y nada más que eso. Lo que constituye su especificidad jurídica. Bajo la variante en estudio, lo que se pretende disciplinar es la incompatibilidad de las actuaciones procesales en sentido amplio, que puedan producir un retroceso al alcance de la tutela jurisdiccional, bajo los parámetros de la debida defensa procesal.

El juzgamiento de dichas actuaciones es reducida a discurso jurídico, en el cual se analiza la incompatibilidad. Desde el punto de vista lógico, la "incompatibilidad" se refiere a que dos enunciados, proferidos o escritos, no pueden ser sostenidos conjuntamente: ' $\neg(x \wedge y)$ ' ${ }^{82}$. Esta idea de conjunción lógica sólo es para el análisis del discurso de revisión de la disposición de los actos procesales. Desde el punto de vista procesal, el discurso hará referencia a una conjunción fáctica: que dos cosas sean presentadas a la vez, según veremos. Por lo anterior es que el análisis lógico, no se aplica directamente a los hechos o actos fácticos del proceso.

B.1- La primera pregunta que se necesita hacer es: ¿qué es lo incompatible a lo que se imputa preclusión? Aquí podemos distinguir los argumentos, de los medios o actos de defensa. Los argumentos, en el proceso, ciertamente se expresan a través de los actos o medios procesales, por lo que pueden ser sometidos a tal régimen. A veces, un argumento se agota en el acto, identificándose con él en una relación de uno a uno; en otras, va contenido en un acto junto con otros argumentos, en tal caso hay que distinguir si el argumento se agota en una facultad procesal, como la de interponer una excepción o una deducción específica, v.gr., la excepción de pago, una deducción reivindicatoria, o, por el contrario, si varios argumentos construyen el ejercicio de una sola facultad. Cuando no se identifica con una facultad procesal o acto, se trata de un argumento en puridad. En este caso, los argumentos se evalúan como tal, y si son incompatibles por un problema lógico-metodológico, entonces éstos pierden su valor racional, para justificar la teoría del caso; por tanto, quedan fuera del régimen de la preclusión, pero no de la incompatibilidad (para la eventual procedencia de, p.ej., la prohibición del acto propio ${ }^{83}$.

B.2.- En el mundo procesal, se puede decir que dos medios son incompatibles, cuando no se pueden sostener o enunciar a la vez en el proceso (es decir, de manera simplemente conjunta) por la misma parte, en razón de sus alegaciones. Así, p.ej., dispone el art. 17 inc. 1 CPC: "En un mismo juicio podrán entablarse dos o más acciones con tal que no sean incompatibles". De ahí surge la pregunta: ¿qué es lo que origina tal incompatibilidad en este contexto?

82 G. von Wright, dice que también puede escribirse como modalidad alética ' $\neg M\left(x_{\wedge} y\right)$ ', es decir, que su conjunción es imposible (y compatible si es posible). Ensayo de Lógica Modal. Rueda, B. Aires, 1970, pp. 28 y 29.

83 Otra figura que contribuye a limitar la incompatibilidad de conductas por contradicción es la del mencionado acto propio (vid. E. Gandulfo, "La Aplicación”, cit. nota n. 13, pp. 363 y ss.). No obstante, L. Díez-Picazo, siguiendo a d'Onofrio, señala que el acto propio no tiene cabida en el proceso, pues se consume en la preclusión por incompatibilidad. La Doctrina de los Propios Actos. Un Estudio Crítico sobre la Jurisprudencia del Tribunal Supremo. Bosch, Barcelona, 1963, pp. 180 a 182. 
B.3.- A mi juicio, en una primera aproximación puede verse que la causa que la origina, es el diseño jurídico de los medios que se pretenden hacer valer. La construcción jurídica de la clase a que pertenecen los medios o actos en juego, se encuentra en una especial relación con el objetivo jurídico o consecuencias de dichos medios o figuras.

B.4.- Pero tal criterio jurídico debe ser pragmático, en el sentido de que las consecuencias jurídicas que delinean el objetivo jurídico del medio, deben producir en el caso, una afectación al correcto orden jurídico procesal y sus objetivos perseguidos, y que redunda en la resolución misma del problema. Específicamente, la conjunción de medios con este rasgo, produce que el juez no pueda solucionar las dos peticiones a la vez en el proceso, sea porque: $a$ ) al satisfacer una deja sin objeto a la otra o porque la consecuencia de resolver favorablemente una hace imposible resolver la otra (produciendo actos de cognición innecesarios), y el tribunal seguiría con el deber de resolver la petición pendiente; o bien, $b$ ) puede permitir resoluciones contradictorias, según veremos en los ejemplos. Ello provoca, en el mejor de los casos, la ambigüedad e incertidumbre sobre la forma y prelación para resolver y, en el peor, resoluciones contradictorias o bien se provoca un retroceso del proceso. De ahí el principio de que no deben presentarse peticiones incompatibles a los tribunales.

La incompatibilidad pragmática puede producirse, sea porque el objetivo jurídico del medio o figura es disímil o porque tiene el mismo objetivo. Cada situación debe analizarse por separado:

a) Si el objetivo jurídico es el mismo: se trata de dos medios o más, que pertenecen a una misma clase. Ahora bien, es sabido que las clases pueden ser construidas en base a cualquier criterio arbitrario, siempre que sea repetible para todo potencial miembro de la misma; pero, en nuestro caso, la idea es que el criterio con que se juzga es jurídico, y tiene relación con una identidad de consecuencias buscadas. P.ej., el recurso de reposición busca impugnar una resolución y el de apelación busca también impugnar una resolución, la nulidad procesal (arts. 83 y 84 CPC), pretende privar de valor a una resolución judicial como también lo pretende la casación forma y fondo. En la misma línea vemos que si se acepta el recurso de reposición, frente a una apelación, se corrige el agravio, pero la apelación vigente, o bien, podría resolverse en contrario, produciéndose una contradicción, o bien, quedaría sin objeto.

Pero la identidad de consecuencias, pasa por la identificación, a su vez, del tipo de consecuencia buscada; y esto importa un problema lógico de nivel o generalidad: porque un medio probatorio, que busca probar algo, puede precluir y no por ello va a hacer precluir a otro medio que busque probar lo mismo. El punto es que con pequeños movimientos argumentativos, de juego de generalidad o especificación, un mismo medio puede ser compatible o incompatible para el mismo juicio. 
Sobre preclusiones procesales en el derecho chileno en tiempo de reformas. Ensayo de una teoría general desde un enfoque valorativo jurídico.

Para evitar aquello, el específico nivel con que se evalúe -insisto- debe pasar por los objetivos de la preclusión, pero, además -como también ya se indicó- enmarcado dentro de la construcción procesal. Esto último implica que si la construcción del procedimiento da la oportunidad para evacuar todos los medios, como en el caso probatorio, no se produce la preclusión, y se debe restringir el nivel de generalidad; al constreñirse tal ámbito, muchos de los actos procesales que en la generalidad tenían la identidad de objetivo, ya no la tendrán y dejarán de ser considerados incompatibles, p.ej., en el caso de los testigos, habría que reconducir el objetivo a la deposición de los testigos, dejando fuera al resto de los medios. Pero el proceso está construido para presentar diversos testigos, por lo que no hay incompatibilidad en presentar varios, con lo que no hay tope. Además, desde el punto de vista consecuencial, no hay óbice para la correcta administración de justicia, ni para el dictado de la sentencia, en que la ley no sólo permite apoyarse en varios medios de prueba, sino que lo estima como necesario. Lo que no ocurre en el caso de las acciones o recursos con el mismo objetivo a obtener, en que el diseño legal del proceso y su resolución, no permite la conjunción, pues si se concede uno, el otro queda pendiente y tiene que resolverse, quedando imposibilitado el tribunal de concederlo a pesar de que sus supuestos puedan así estimarlo (y, por ende, debiendo por ley concederlo), pues ya otorgó lo pedido con el otro. El tribunal queda así en la incómoda posición de infringir el Derecho; lo que constituye el índice de la viabilidad de la posibilidad del diseño legal del proceso.

b) En el caso de los medios de disímil objetivo, la situación es un tanto parecida a la última anteriormente vista. En principio, si es disímil el objetivo, no debería tener mayor problema, porque se trata de medios que no se repiten. No obstante, es necesario entrar a evaluar la situación desde el punto de vista pragmático. Para que se dé el caso de incompatibilidad, las consecuencias no deben permitir la realización, ni la concesión de ambos medios a la vez por parte del tribunal; se trata en el fondo de una contradicción de lo pedido: no se puede conceder ' $a \wedge \neg$ '. Típicamente se cita el ejemplo de una demanda de resolución de contratos y a la vez de cumplimiento forzado in natura, en que no pueden ser concedidas a la vez por el juez, produciéndose una ambigüedad en la discusión y eventual acogimiento. Asimismo, p.ej., en la prórroga tácita de competencia: si se interpone una demanda civil en un territorio de competencia que por tal factor no corresponde y el demandado contesta sin alegar la excepción dilatoria de incompetencia, entonces se produce la prórroga, porque realizó un acto que no consistió en alegar la incompetencia del tribunal que conoce del asunto, para sacar la causa de allí; precisamente continuó tramitando en él (art. $187 \mathrm{n}^{\circ} 2$ COT). Aquí derechamente se busca evitar los retrocesos y ambigüedades provocados por la conducta de la parte. En este sentido, se requiere un conocimiento técnico sobre las consecuencias de los medios usados, para evaluar aquella que importe una contradicción con otra derivada de otro de los medios utilizados.

B.5.- ¿Cuándo ocurre la incompatibilidad preclusiva en materia procesal? La incompatibilidad preclusiva se puede producir desde que se presenta el acto o se realiza la 
facultad procesal, hasta que se agota con su objetivo. Y aquí podemos distinguir si el objetivo se logra o no y/o si el efecto es permanente.

En cuanto a esto último, el efecto permanente, podemos ver lo siguiente. p.ej., una demanda de tutela jurisdiccional se proyecta sobre el resto del proceso. Entonces, la incompatibilidad es permanente en el proceso, por lo que, y siguiendo la dirección del art. 17 CPC, las pretensiones incompatibles con la primera no pueden presentarse (o acumularse) por la misma parte en todo el proceso ${ }^{84}$. También puede verse el siguiente caso: si se acepta un recurso por resolución judicial, el efecto del recurso aceptado, esto es, la validez de aquella resolución, se proyecta sobre el proceso; a veces, por completo, vgr., la reposición de la interlocutoria de prueba; otras, solo parcialmente, como cuando se trate de un mero auto.

Si el objetivo del medio procesal no se logra y su efecto es transitorio, entonces la incompatibilidad cesa con la extinción del medio y de su efecto. p.ej., en el caso de un recurso rechazado, la validez de la resolución genera un cierto estado de cosas normativo, al cual todos deben atenerse, y la parte perdidosa estará habilitada para adoptar una conducta en concordancia con lo ordenado por la propia resolución, inconsistente con su conducta anterior, desapareciendo así la incompatibilidad. De esta manera, se tiene la flexibilidad necesaria y el respeto a las expectativas procesales legitimas, generadas en el ejemplo por las propias resoluciones judiciales (vid. B.10).

B.6.- Forma de operar de la preclusión. Si se plantean dos medios incompatibles, en un mismo acto o momento, pueden tomarse dos vías. Por el principio de conservación de los actos, si se trata de peticiones presentadas de manera formalmente diferentes, de manera que permitan discursivamente la separación, en particular, cuando se plantea en un escrito separaciones de lo principal y de varios otrosíes con orden de prelación, léase primero, segundo, tercero en relación con lo del principal, puede estarse a tal orden para declarar precluido el medio hecho valer de manera formal y discursivamente postrera. Ej., se plantea en lo principal, la reposición, y en un otrosí, un incidente de nulidad; lo principal planteado muestra lo primario y que, en general, es más importante, por lo que la reposición debe subsistir y la apelación perder valor; de tal manera al decaer uno se salva el otro.

Pero si todos los derechos o excepciones van en un sólo acto y escrito, y no hay manera formal de separarlos, entonces, se anulan las alegaciones incompatibles y decae toda la unidad, es decir, el acto completo.

Cuando se trata de una formalidad oral concentrada, el juez con potestades de dirección

84 Por la misma razón, no se puede acumular, así sin más, p.ej., a una demanda de resolución de contratos, una demanda de cumplimiento forzado. 
Sobre preclusiones procesales en el derecho chileno en tiempo de reformas.

Ensayo de una teoría general desde un enfoque valorativo jurídico.

del buen proceso puede sanear el vicio, forzando a la parte, en el acto de la audiencia, a optar por una u otra variable de la conjunción. Creo que ello debiera ocurrir en la medida que, o bien, la contraparte exija su rectificación, como medida dilatoria o correctiva del procedimiento (es decir, como excepción formal), o bien, si el juez lo obliga antes de la contestación reconvencional de la contraria. Si la contraria hace valer la incompatibilidad de manera perentoria o de fondo, para el caso o incidente, el juez debe dejarlo para la decisión de fondo del incidente o para definitiva.

B.7.- En este tipo de preclusiones, el Derecho ofrece, en general, una mayor flexibilidad, para evitar las preclusiones. En efecto, la principal forma de evitarlas, no obstante plantear o presentar conjuntamente medios incompatibles, es "modalizar" dicha conjunción mediante la usualmente conocida cláusula modal "en subsidio" o regla de "eventualidad". Precisamente, éste es el mecanismo diseñado para evitar el supuesto preclusivo de la incompatibilidad. Así también lo entiende el legislador. Por ejemplo, el art. 17 CPC norma que en un mismo juicio pueden entablarse dos o más acciones compatibles. Sin embargo, "podrán proponerse en una misma demanda [es decir, conjuntamente], dos o más acciones incompatibles”; ¿pero cómo puede ocurrir ello?, la ley manda "para que sean resueltas una como subsidiaria de otra" ${ }^{85}$. Es decir, el modo en subsidio, en algún sentido, deshace la incompatibilidad inicial. Otro tanto se puede ver en el recurso de nulidad, éste debe interponerse conjuntamente y de manera subsidiaria a la apelación (art. 450 inc. 2 CPP: "En el evento de interponerse ambos recursos, deberán deducirse en forma conjunta en un mismo escrito, uno en subsidio del otro"). Lo anterior puede extenderse aun a las alegaciones mismas, pues como se señala en el recurso de nulidad, éste se puede fundar en varias causales conjuntamente, debiendo indicarse si se presentan de manera simplemente conjunta, cuando son compatibles o bajo la modalidad subsidiaria, si hay incompatibilidad (art. 378 inc. 2 CPP) ${ }^{86}$. Lo mismo rige en materia de peticiones de la acusación y requerimiento sobre pena imponible (arts. $259-C$ y 462 inc. 3 CPP). En materia de impugnación

85 En sentido coincidente R. Tavolari, quien explica un caso diciendo que, el CPC "en caso alguno modifica u olvida el principio básico sustentado en el art. 17, en el sentido que a los tribunales no pueden formularse peticiones incompatibles como no sea proponiéndolas en subsidio de las otras”. Recursos de Casación y Queja. Nuevo Régimen. Lexis Nexis, Santiago, 1996, p. 52.

86 La Corte de Apelaciones de San Miguel, en el caso 'contra Vergara Sandoval, F.', sostuvo la necesidad de guardar correspondencia en todo lo planteado como subsidiario, esto es, entre las causales invocadas (en subsidio) y las peticiones (subsidiarias). El escrito del recurso de nulidad sub lite se presentó "sin señalar si las causales se oponen de forma simplemente conjunta o en subsidio y, si se anula el fallo o el proceso oral respectivo" (según las causales invocadas). Se dictaminó que "cabe requerir que entre los basamentos de la invalidación alegada y las peticiones concretas dirigidas al tribunal ad quem, exista una lógica concatenación, en el sentido que las peticiones concretas sean exactamente congruentes con los fundamentos que les preceden, en tanto son consecuencias jurídicas de éstos". Y se agrega que "el artículo $378 \ldots$, refuerza lo anterior, al indicar que en el evento de fundarse el recurso en varias causales, cada motivo de nulidad deberá ser fundado separadamente [lo que origina la posible incompatibilidad], de modo que a cada específico fundamento expresado deberá necesariamente corresponder una concreta, petición coherente con aquel razonamiento". (Sentencia de 27 de diciembre de 2005, redactada por el juez P. Donoso Gomien, Gaceta Jurídica, No 306, 2005, pp. 249 y ss.). 
de decretos judiciales, confluyen o son admisibles, tanto la reposición como la apelación, por lo que el Derecho establece que la apelación deba interponerse en subsidio de la reposición (arts. 188 y 319 inc. 3 CPC).

La ley puede obliterar aquella solución, en ciertos casos, pero ello importa cercenar una facultad de defensa procesal. Este cercenamiento puede tener razones justificadas o no, pero debe siempre tener presente que se está limitando una parte del derecho de defensa. Tal rigidez, aunque justificada, la vemos en el caso de la cuestión de competencia por vía de inhibitoria y declinatoria, ante tribunales distintos; se ordena que no puedan interponerse de manera simultánea (art. 101 inc. 2 CPC), lo que parece razonable para no duplicar el trabajo de dos tribunales, evitando decisiones contradictorias, que traigan incertidumbres en la tramitación del proceso, estableciendo así un procedimiento que salvaguarde los derechos de las partes.

El sentido técnico de esta modalidad es plantear una relación de orden entre dos cosas, en el sentido de marcar una precedencia, mediante la subordinación de una a la suerte o destino de la otra (la principal). Tal subordinación se refiere a la prelación en la entrada en examen y resolución por el tribunal del medio planteado. La segunda se subordina mediante una condición negativa: de no resultar acogida la primera, por cualquier causa. Así, lo muestran los arts. 188 inc. 1 y 319 inc. 3 CPC, que expresamente enuncian que la apelación "subsidiaria" de la reposición se "interpondrá"... "para el caso de que ésta no sea acogida". El art. 17 inc. 2 CPC resalta el aspecto resolutorio de la cláusula: "para que sean resueltas una como subsidiaria de otra”. La causa del paso a la siguiente puede ser por cuestión de admisibilidad o de fondo (siempre que el mismo defecto no afecte también a la subsidiaria, p.ej., cuando se traspasan los límites temporales de los recursos de apelación y casación presentados de manera conjunta ${ }^{87}$.

Si la condición no se cumple, al ser subsidiaria la segunda, ésta queda sin efecto de acogerse la primera. Dicho principio general lo recoge expresamente la ley en el art. 808 inc. 2 CPC, en orden a que si se interponen a la vez recurso de casación en la forma y en el fondo, entonces "Si se acoge el recurso de casación en la forma, se tendrá como no interpuesto el de fondo"; es decir, aquí no se da el evento negativo.

En el fondo, podemos observar que es la "eventualidad" la que está detrás de todo esto (vid. A.4). Y ello nos da pie para mostrar que esta modalidad, no se expresa solamente con una cláusula sacramental de "en subsidio". Dado que es la eventualidad la que está en el fondo de la modalidad, la interposición de los medios debe hacerse expresando que es para "el evento" 
Sobre preclusiones procesales en el derecho chileno en tiempo de reformas.

Ensayo de una teoría general desde un enfoque valorativo jurídico.

o "el caso" o "en subsidio" (como expresan los arts. 188 y 319 CPC "para el caso...") o con cualquier fórmula que exprese dicha condicionalidad. De esa manera, el tribunal debe someterse a la modalidad expresada en la formulación de los medios.

El sentido de la modalidad "en subsidio" es de ser un mecanismo para evitar la preclusión por incompatibilidad exclusivamente. Y no de una mera forma exigida por la ley en ciertos casos taxativos. De ahí que deba evitarse dos creencias erróneas sobre este punto:

- $\quad$ No se trata de una cláusula de accesoriedad que indique que un medio existe en base a otro principal y, por tanto, provoque una fusión de sus regímenes en torno a este principal, por el sólo hecho de invocar la modalidad, de tal manera que sólo existiendo el principal pudiese existir el segundo (y caído el principal decayese también el accesorio). Por el contrario, si bien la modalidad "en subsidio" se usa para posibilitar el planteamiento conjunto de dos o más peticiones, al tener por objeto fijar el orden de su examen, por su sola razón no provoca una fusión de regímenes, sino que cada una mantiene su régimen, vgr., de plazos. Son las normas legales las únicas que pueden operar la mencionada fusión, así como ocurre en los casos de la apelación y la reposición de los arts. 188 y 189 CPC, de la casación con la apelación por el art. 770 inc. 3 parte $1^{\mathrm{a}} \mathrm{CPC}$, en donde se ordena expresamente la fusión de plazos. Bajo dicha consideración, la Corte de Apelaciones de Valparaíso, en sentencia de 9 de junio del 2006 -de causa del antiguo sistema penal-, dispuso que "esta Corte... entiende que, tanto el recurso de reposición como el de apelación [puesto en subsidio], son autónomos y tienen nomenclatura propia en lo relativo al plazo para interponerlos, todo a menos que la Ley expresamente disponga lo contrario" ${ }^{88}$. Similar razón puede verse en materia de recursos en contra del fallo de petición de extradición, según el art. 450 inc. 2 del CPP nuevo.

- Tampoco debe interpretarse con la regla de contrario, esto es, que cuando la ley no prescriba la forma modal "en subsidio", entonces se ha de entender que la prohíbe o, lo que es lo mismo, exige que se presente un medio de manera directa e individual, p.ej., la apelación directamente y no en subsidio de una reposición, o bien, que está exigiendo que dos medios se presenten de manera simplemente conjunta, p.ej., un recurso de casación en el fondo conjuntamente con el de forma sin modalidad alguna. Ello revela un profundo desconocimiento de la razón, operatividad y alcance de la figura en análisis. No hay una relación simétrica entre que la ley prescriba su presencia y la falta de dicha prescripción, precisamente a causa de que la formalidad sólo tiene el fin de evitar la preclusión de los medios invocados, mediante el mero establecimiento de un orden de prelación en la revisión 
de éstos. De tal manera que con la cláusula modal, si un medio no es procedente, entonces la jurisdicción debe pasar a la revisión del otro. Así lo indica expresamente la ley; vgr: "La apelación en contra de la resolución del artículo 318 sólo podrá interponerse en el carácter de subsidiaria de la reposición pedida y para el caso de que ésta no sea acogida" (art. 188 inc. 1 CPC). $i$ ) Respecto de la errada idea de que, su falta de prescripción implicaría la exigencia de una interposición directa e individual (vedando la cláusula), en especial, podemos ver que, cuando, p.ej., se contempla el recurso de apelación en contra de una resolución, sin pedir la cláusula en subsidio, le está dando a la parte el beneficio de ahorrarse de tener que pasar por el trámite de la revisión por el propio tribunal que la dictó (mediante reposición, si tiene competencia para ello), pero lógicamente nada dice de si es que se pueden o no presentar en la modalidad en subsidio dos o más recursos. Precisamente porque esa fórmula legal, técnicamente, no está diciendo nada acerca de la preclusión o de cómo evitarla. De guisa, igualmente la parte agraviada puede hacer intervenir la cláusula en subsidio, pues, en estos casos, ella mira a los medios o recursos, más específicamente a evitar su pérdida cuando estén en conjunción. Y el orden de estudio que ordena la cláusula, permitirá, precisamente, que la falencia del primero haga procedente la revisión del segundo recurso. Obsérvese que esto se corrobora en la letra de la ley, pues correctamente ella no dice ni ordena la interposición directa de un tipo de recurso en particular, tan sólo prescribe si el recurso es procedente en ciertos casos, 'será procedente el recurso...' (p.ej., arts. 187, 189, 326 inc. 1 CPC), y aparte vemos los casos en que sí ordena la intervención de la cláusula "en subsidio" (p.ej., art. 188 CPC). Desde el punto de vista pragmático, ello es coherente con la forma del beneficio, pues en diversas ocasiones es sumamente dudoso y con opiniones judiciales dispares, sobre qué recurso es procedente, por lo que la parte puede prescindir del beneficio de ahorro, para evitar la pérdida del medio de defensa, que es lo que importa. Otro ejemplo bien claro en el mismo sentido es lo que ocurre en materia de excepciones dilatorias y la contestación en el juicio ordinario. La ley le da al demandado el beneficio de no tener que preparar la contestación y las dilatorias de inmediato. La contestación puede ser interpuesta una vez que se resuelvan las dilatorias (art. 308 CPC). Perfectamente, y así ocurre a veces en la práctica, el demandado puede interponer sus dilatorias y la contestación en subsidio (a veces le interesa una resolución rápida del asunto), ya que el plazo de la contestación está puesto a favor del demandado, el cual tácitamente está renunciando a él, si no se acogen las dilatorias; lo que muestra que, efectivamente, aun cuando la ley no prescriba esta forma, las partes tienen vía libre para modalizar sus actos propios de defensa, según su estrategia privada. ii) Respecto a la supuesta necesidad de interposición simplemente conjunta, como en el caso de los recursos de casación fondo y forma, aparte de lo expuesto, podemos ver que la mera ausencia de mención legal expresa a la cláusula no acaba con la incompatibilidad ni con los problemas que acarrea (por ende, no acaba con el principio de no interponer peticiones incompatibles). Para evitarlos siempre se deberá recurrir a la modalización; por ello, aunque no lo diga expresamente, el legislador en el art. 818 inc. 2 CPC tuvo que reconocer que los dos recursos siempre se interponen para la eventualidad quiérase o no, 
Sobre preclusiones procesales en el derecho chileno en tiempo de reformas. Ensayo de una teoría general desde un enfoque valorativo jurídico.

es decir, subsidiariamente (alguna referencia mínima a dicho evento del art. 818, va siempre involucrada en los recursos). Por ende, exigir la formalidad de apelación o de casación, sin cláusula modal, es poner una exigencia extrajurídica y muestra una falta de entendimiento de la ratio de las formas procesales.

El problema que sí ocurre con la cláusula en subsidio, se da cuando se presentan dos medios compatibles. En efecto, en tal evento, por la expresa orden de la prelación del subsidio, no pueden revisarse ni acogerse los dos medios a la vez (aunque sean compatibles). Porque conceptualmente se está precisando que se entre al examen de un medio cuando ya se ha desechado el otro.

¿Cómo se determina cuál debe ser la petición subsidiaria de la principal? No hay una regla generalísima, por lo que vamos a ver ciertas situaciones.

a) En materia de excepciones, alegaciones o deducciones, primero se interponen las procesales o de corrección del procedimiento, y, en subsidio, las de fondo, que presuponen la corrección formal del procedimiento, y en base a ello atacan el mérito de la causa. En el caso de las excepciones dilatorias, en los juicios orales, son éstas las que se interponen primero, y marcarán el orden del fallo; así lo reconoce el art. $61 \mathrm{n}^{\circ} 2$ inc. 2 LTF, que faculta a fallarlas de inmediato. La ley procesal penal las califica derechamente como excepciones de previo y especial pronunciamiento (art. 264 CPP).

b) Por la misma razón, igual solución ha de aplicarse a los recursos procesales: los que atacan el fondo o mérito de la resolución judicial, se deben interponer en subsidio de las que apuntan a los vicios formales. La Corte Suprema ha señalado algo más o menos parecido en materia de recursos de casación, pues "al deducir el recurso en examen [casación de forma como segundo], sólo para el evento que el de fondo no sea aceptado, valida o refrenda los vicios, que luego intenta revivir dado el supuesto que sus alegaciones de fondo no sean aceptadas, lo cual atenta contra el principio genérico de la nulidad procesal". Y agrega que el "orden lógico en que se deben interponer ambos recursos de conformidad a lo estatuido en el artículo 770 del Código de Procedimiento Civil, es primero el de forma y en segundo término el de fondo y no a la inversa como se procedió en el presente caso, porque habiendo esta Corte emitido pronunciamiento sobre la cuestión de derecho a ella sometida al resolver el primero de los recursos planteados, está impedida en virtud de haber operado la preclusión de examinar una causal que se funda en un presunto vicio de procedimiento, que pretende nada menos que llevarla a invalidar su propia sentencia" 89 . 
c) También los más generales son puestos en subsidio de los más específicos; en razón del orden señalado, no obstante que se vea el principal y se lo rechace, aún así es posible entrar a revisar el más general, pero no al revés pues el más general absorbe al más específico.

¿Qué sucede si interponiéndose en la eventualidad, no se hace en aquél orden? En un caso se ha sostenido, en materia de presentación de recursos de casación de fondo primero y luego de forma, que precluye la presentación conjunta, fundado en los principios de la nulidad procesal ${ }^{90}$. Sin embargo, tal solución no es consistente con la calificación jurídica de la modalidad eventual o subsidiaria, confunde las argumentaciones de mérito y de forma y, en particular, en estos recursos, muestra un error conceptual con la calificación de "estricta" de los mismos. i.- Primero, el argumento de los principios de la nulidad procesal, afectan al recurso de casación en la forma exclusivamente, y no se extienden al recurso de casación en el fondo, a causa de la naturaleza de este último. Por ello, el argumento si bien es válido en relación con el recurso de forma, no afecta al de fondo, por lo que su procedencia sigue en pie y requiere ser examinada por otros criterios. ii.- Luego, la cláusula en subsidio, al establecer por su propia naturaleza un orden de prelación de estudio, prioriza y protege al primer o principal recurso interpuesto, por lo que nuevamente queda a salvo del vicio detectado por la corte. iii.- Tiene que ver con dos consecuencias del concepto de "Derecho estricto", una negativa y otra positiva. La negativa: si bien el recurso de casación es stricti iuris, dicha calificación conceptualmente no tiene nada que ver con la subsidiariedad, lo que se corrobora legalmente con el estatuto del recurso de nulidad (art. 478 inc. 4 CdT y art. 378 CPP que reconocen la modalidad subsidiaria). La positiva: al ser stricti iuris obliga a la Corte a tener una interpretación apegada a lo literal del recurso. Entonces, la literalidad del recurso impone, por la cláusula en subsidio, a entrar en examen primariamente de 'lo principal', aunque ello sea lo de fondo, sin entrar a juzgar lo subsidiario, por lo que juzgar al revés es invertir antijurídicamente los términos del recurso, extendiendo muchísimo más allá lo planteado por el propio recurso. En suma, la solución de dicha tesis fue mala, técnicamente hablando, siendo que lo que corresponde por la violación del orden interno es entrar a lo principal, sin consideración de lo subsidiario.

B.8.- Pero obsérvese que esta situación subsidiaria, directamente no afecta a la certeza, ni la prontitud del juzgamiento ni a la defensa, porque, como vimos, mediante la cláusula "en

que los dos recursos de casación no pueden interponerse de manera subsidiaria. No obstante, y acto seguido, incurriendo en una contradicción, ella misma explica cómo se produce la incompatibilidad de los dos recursos, y agrega incluso la consecuencia propia de la cláusula en subsidio que indica el art. 808 inc. 2 CPC, esto es, que acogido uno se desecha el otro recurso. Aparte de ello, y lo interesante de la sentencia, es que aplica una subsidiariedad de hecho o presupuesta, cuando señala el orden en que deben interponerse para proceder su examen, pero lo curioso o erróneo es que sin reconozca que haya una cláusula que habilite tal orden. 
Sobre preclusiones procesales en el derecho chileno en tiempo de reformas. Ensayo de una teoría general desde un enfoque valorativo jurídico.

subsidio" se logra plantear lo mismo. Es por ello que esta forma protege al buen orden jurídico en el sentido de llegar a una resolución final de un incidente o de todo el proceso, de forma saneada, en vista a que el tribunal no se vea forzado a dictar una sentencia contradictoria o que no pueda fallar alguna parte de la petición.

B.9.- El tribunal al resolver y acoger la petición principal, no podrá pasar a resolver la que esté en subsidio, como corrobora el art. 808 inc. 2 CPC. De esta manera, en el caso de que el tribunal a quo no falle la petición subsidiaria consistente, p.ej., en la apelación, entonces se deja abierta la competencia de la Corte de alzada, para entrar a conocer y fallar las cuestiones incompatibles con lo resuelto en primera. Así, el art. 208 CPC prescribe que: "Podrá el tribunal de alzada fallar las cuestiones ventiladas en primera instancia y sobre las cuales no se haya pronunciado la sentencia apelada por ser incompatibles con lo resuelto en ella, sin que se requiera un nuevo pronunciamiento del tribunal inferior" ${ }^{\prime 1}$.

B.10.- La consecuencia de incurrir en los supuestos de incompatibilidad, no está del todo clara para cualquier caso. Por una parte, sabemos que, si se presentan juntos los medios, ' $A$ ' y ' $B$ ', entonces precluye el que no se presentó en subsidio (' $B$ ').

Pero el punto está en ¿qué ocurre si se presenta después el segundo acto (' $B$ ')?

Observado desde un punto de vista analítico, si la parte no ejerce conjuntamente o a la vez los actos en el proceso, en los términos antes expuestos (en B.5), no se produce la preclusión por incompatibilidad. Tómese muy en cuenta que la incompatibilidad supone siempre dos $o$ más variables, en principio, válidas de defensa, y no va más allá.

En tal línea deben descartarse del ámbito de la incompatibilidad preclusiva las siguientes situaciones:

a.- i) Una vez ejercido un medio, p.ej., un recurso, y logrado su objetivo mediante su acogimiento, en principio no hay para qué volver a ejercer la facultad incompatible; carece de interés procesal. ii) Lo mismo rige si se ha aceptado por la parte la resolución, se carece de interés procesal, para atacarla posteriormente. iii) Además, podemos tener una situación similar, en donde una parte opte por otra solución que la originalmente expuesta por ella y ganada. P.ej., el juez decreta de oficio la nulidad de lo obrado en el probatorio, por falta de notificación formal del interlocutorio de prueba del art. 48 CPC (único medio de tener por notificado, según una vieja tesis excluyente de otras formas de notificación), no obstante que las partes evacuaron todos sus medios de manera legal en 
él. El actor repone en contra de ella con una tesis no-excluyente (por no ser la única forma de toma de conocimiento válida la notificación formal, basado en el art. 55 inc. 1 CPC -notificación ficta-, y por falta de perjuicio al presentar ambas partes sus listas de testigos en tiempo y forma, desde que tomaron conocimiento). El demandado defiende dicha nulidad estricta por la tesis excluyente del juez. La reposición es rechazada. Posteriormente, el demandado pretende objetar la presentación de la nueva lista de testigos del actor, por estar fuera de plazo contado desde que se notificó la resolución de la reposición y de que el actor tomó por otra vía conocimiento del interlocutorio de prueba, sin necesidad de notificación formal del art. 48 CPC, adoptando así la tesis defendida por el actor en su reposición, precisamente la contraria por aquél defendida en un principio. Este caso no queda protegido por la preclusión, pues está ejerciendo otra facultad contra otra situación particular, y no está tutelando el correcto orden de disposición de los actos en el proceso jurídico. Pero sí puede quedar protegido por la regla de prohibición del acto propio, al afectarse derechamente una expectativa justificada (en el ejemplo, originada en parte por la conducta promovida por la parte). iv) Otro caso a analizar es si la parte renuncia a los recursos procesales, y luego pretende interponer algún recurso. Esto tampoco está cubierto por la preclusión, pues su facultad se extinguió no por nuestra figura, sino por algo más simple, derechamente su acto de disposición de la facultad procesal de recurrir, mediante la cual se autoprivó de ella ${ }^{92}$. v) Un caso más especial es el de las tercerías de prelación y de pago. Ambas tienen por objeto el pago de los terceros acreedores sobre un fondo común. El punto estriba en que, si alega respecto de un mismo crédito, tanto la tercería de prelación como la de pago, podría estimarse que una de las dos no podría cumplirse eficazmente, no obstante que hubiese dinero para el pago. Por ello es que, si ambas se interponen conjuntamente por el mismo tercero, debe hacerse de manera subsidiaria la de pago a la de prelación. Pues bien, ¿una vez acogida y agotada la de prelación, puede presentarse la de pago, por el remanente del crédito? No hay inconveniente alguno, pues sólo se tiene como límite de la posibilidad de interponer la tercería, el que existan bienes aún en especie o en dinero. Además, dado que son dos acciones igualmente legítimas para el cobro, y que si la tercería de prelación se agotó, quedando remanente, entonces ésta ya no existe y no hay acto con valor actual con que contrastar la compatibilidad. Obsérvese que la ley procesal civil tampoco ha impuesto limitación alguna a la manera de presentar las tercerías ${ }^{93}$. Lo mismo puede decirse en relación con las tercerías de posesión y de dominio.

b.- Si ejercido el medio, éste es rechazado, desaparece la incompatibilidad, porque desaparece totalmente de la vida procesal el acto primero (' $A$ '), con el cual podría haber sido

92 En contra en este último ejemplo, L. Marinoni, Manual, cit. nota n. 15, p. 655.

93 Como dice E. Couture, los "litigantes deben hacer valer sus defensas conjuntamente cuando la ley así lo dispone". Fundamentos de Derecho Procesal Civil, $3^{\text {a }}$ edic. Depalma, B. Aires, 1958, p. 197. 
Sobre preclusiones procesales en el derecho chileno en tiempo de reformas. Ensayo de una teoría general desde un enfoque valorativo jurídico.

incompatible el segundo acto (' $B$ '), y la nueva resolución establece un cierto estado de cosas normativo a que deben todos atenerse. Así, p.ej., una parte puede sostener en un recurso el vicio de una resolución pidiendo su invalidación, el recurso es resuelto de manera negativa, y después presenta un recurso fundado en tal resolución pidiendo que se cumpla para determinados efectos. No hay incompatibilidad preclusiva, no obstante que sus fundamentos y las peticiones sean, en principio, contradictorios. La resolución decide el asunto y pone certeza en el proceso, es decir, con su validez ordena a qué deben atenerse oficialmente las partes ${ }^{94}$, lo que temporalmente rompe el criterio de contrastación de la incompatibilidad.

Por todas las razones expuestas es que, cuando surja la necesidad jurídica de la conjunción de dos o más medios, el legislador tenga que optar por dos de los siguientes tipos de limitaciones:

i.- $\quad$ La conjunción y la preclusión por falta de oportunidad. Lo que ocurre en estos casos es que debe revisarse, si concurren los supuestos normativos que obliguen a la parte, a presentar los medios de manera conjunta en cierta oportunidad (p.ej., casación y apelación según el art. 770 inc. 3 CPC), pues en tal caso opera otra subfigura: la preclusión por falta de oportunidad (existe aquí un forzamiento a la acumulación eventual); consecuencialmente, no va a poder presentarse sucesivamente el medio incompatible, como señala el art. 56 inc. 4 del viejo CPP.

No existiendo tales supuestos normativos, pueden presentarse de manera separada una vez acabado o agotado el primero, sin que exista preclusión. En el caso de las excepciones dilatorias y la contestación, en los procesos escritos, si esta última no se interpone conjuntamente, de manera subsidiaria, en cierto término o plazo, de todas maneras la ley permite que la contestación pueda presentarse en un estadio más avanzado (art. 308 CPC).

ii.- También puede ocurrir que el legislador, sin establecer un plazo o término preciso, ni permitir la acumulación eventual, limite expresamente las facultades sucesivas, sea que se use la facultad de manera exitosa o no. En tal caso se debe optar por uno u otro medio. La razón está en el carácter permanente de una de las vías que se tome.

Así, en materia de cuestiones de competencia, el demandado cuenta con la vía declinatoria, interpuesta ante el tribunal que se piensa es incompetente, y la inhibitoria, para el tribunal que se cree competente. Pues bien, la ley manda que: "Las que hayan optado por uno u otro de estos medios, no podrán después abandonarlo para recurrir al otro. Tampoco podrán 
emplearse los dos... sucesivamente" (art. 101 inc. 2 CPC). En este caso, la resolución que decreta la competencia, frente a, vgr., una inhibitoria, tiene la pretensión de regir para todo el proceso, por lo que la preclusión busca asegurar la permanencia de la decisión, frente a una nueva vía alternativa, como una posible declinatoria.

Lo mismo se puede predicar de la prórroga tácita de competencia. Al contestar la demanda o realizar otro acto, sin interponer las excepciones dilatorias, entonces se está haciendo un acto que supone la mantención de la competencia en ese tribunal en que se contestó; y dicha competencia es la que se pretende que regirá en todo el proceso, por lo que tal carácter permanente hace precluir una eventual excepción dilatoria postrera (salvo las excepciones legales).

B.11.- Limitación en lo fáctico de la cláusula en subsidio. No pueden interponerse pretensiones o excepciones que estén fundadas en hechos, cuyo sostenimiento conjunto sea incompatible, siempre y cuando los hechos sean personales de la parte (G. Chiovenda ${ }^{95}$. La cuestión estriba en que al ser personal, quien invoca necesariamente ha debido saber si es verdadera o falsa la afirmación sobre la ocurrencia o no de un hecho; y justamente la afirmación de la ocurrencia o no de ese hecho no es compatible con la existencia de otro que implicaría su negación. En general, al ocupar ese recurso estaría haciendo uso de la mala fe en la técnica en subsidio -pues la parte debería saber la verdad de ese hecho- por lo que no es admitida la cláusula ${ }^{96}$.

De ahí que, p.ej., el demandado no pueda contestar una demanda de cobro de pesos, sosteniendo primariamente que el acreedor no le ha dado dinero alguno, en subsidio que le ha sido devuelto hace unos ocho meses, y tercer lugar, en subsidio de todo lo anterior, que lo había recibido regalado. Esta situación se identifica porque se alegan diversas versiones de hechos respecto de un único acontecimiento.

Cuestión diferente es la que ocurre cuando se alegan hechos parciales o sucesivos, pues en tal caso no hay la mencionada incompatibilidad. Son parciales, cuando se dice 'nada debo, porque te pagué en parte y en parte me condonaste', y, son sucesivos, cuando se sostiene que el dinero le fue devuelto hace 8 meses, y que después de ello, por cualquier duda, se extendió un finiquito donde el acreedor condonó la deuda de lo que pudiese haber quedado.

Así, G. Chiovenda, Instituciones, cit. nota n. 19, v. I, p. 315.

96 Robert W. Millar señala que, históricamente, el Derecho de USA permitió al demandado, en una suerte de principio de eventualidad, formular todas las excepciones que quisiera, siempre que coincidieran "respecto de la base de hecho". Los Procedimientos Formativos del Procedimiento Civil. EDIAR, trad. Grossmann, B. Aires, 1945, p. 112. 
Sobre preclusiones procesales en el derecho chileno en tiempo de reformas.

Ensayo de una teoría general desde un enfoque valorativo jurídico.

C) Preclusión por Consumición.- El orden y sucesión del proceso, en esta subclase, mira a lo siguiente: una vez que se ha ejercido una facultad procesal, presentando un recurso específico, un medio de prueba particular, un acto defensivo de su posición, sea que lo gane parcialmente o le sea rechazado ${ }^{97}$, entonces la parte perfectamente podría volver a ejercerla.

El punto es que: $i$ ) para que no vuelva a repetirse lo ya promovido, y volver atrás en el proceso; o ii) para que no se pueda modificar lo promovido, volviendo a plantear más temas o variar los ya presentados, sorprendiendo a la contraria que ya ventiló su defensa, la parte que ya presentó el medio, pierde la facultad para volver a hacerlo o modificarlo, porque desde el punto de vista de la preclusión ya consumió su facultad al presentar previamente dicho medio.

C.1.- En principio, poco importa si ha sido bien o mal ejercido el medio. En vista a los fines protegidos, la preclusión ocurrirá con independencia de la corrección o no del acto practicado. Ya realizado el acto y poniendo en marcha la eventual discusión, queda limitado el retroceso o la modificación. Un buen ejemplo lo ofrece el juicio ejecutivo. En aquél, el ejecutado puede ejercer la facultad de oposición a la ejecución, mediante las debidas excepciones exclusivamente. La ley establece un tiempo determinado para hacer valer dicha oposición. Si el ejecutado efectivamente ejerce su facultad procesal y se opone a la ejecución, entonces aquél ya no puede volver a oponerse y se pierde el poder de volver a ejercerla -mediante excepciones. Y ello también abarca el caso en que el ejecutado evacue sus excepciones -aún de fondo- a través de la vía de un erróneo incidente de nulidad procesal, porque precisamente al ser presentadas ya son parte de la eventual discusión procesal y fuerzan a la contraria a contestarlas y exhibirse, desde el punto de vista estratégico-defensivo ${ }^{98}$. Por otra parte, en el nuevo proceso del trabajo vemos que el art. 479 inc. $3 \mathrm{CdT}$, bloquea, expresamente, la alteración o modificación del recurso de nulidad interpuesto, sin tener en cuenta el correcto ejercicio o no de aquél.

Exceptúa la regla de la corrección el efecto retroactivo de la nulidad procesal. Mediante la retrocesión hasta donde sea necesaria, para la tutela de los objetivos propios de la nulidad, se permite la renovación de la oportunidad y forma de presentación de los medios que fueron mal planteados.

Si lo llegase a ganar completamente, no es necesaria la figura de la preclusión, pues se puede resolver por la vía de falta de interés jurídico procesal.

98 En este tipo de situaciones, en razón de la estrictez y complejidades de las formas procesales, se hace conveniente usar la técnica de la "divitio disputatio", para efectos de evitar la preclusión de las cuestiones de fondo. La parte activa que promueve una incidencia, puede pedir la división de la discusión, en orden a que se discuta la cuestión formal de la admisibilidad de la vía, y luego que se discuta el fondo, una vez declarada la admisión. De esta manera, se tutela, además, el derecho de defensa de la parte pasiva, pues sabrá cuándo debe evacuar sus argumentos de fondo, sin tener que exponer y quedar al descubierto en sus argumentaciones de fondo, respecto de una eventual repetición de la discusión en el momento que habría de ser oportuno. 
C.2.- En general, la atribución de la preclusión a este subtipo de supuestos va acompañada de un plazo o término para la realización del acto. Pero, teóricamente, esta última asignación no se la requiere, pues perfectamente se puede dejar una cierta libertad de ejercer la facultad, como presentar un incidente; mas una vez interpuesto se agota la facultad, consiguiendo limitar la extensión del proceso mediante esta vía consumativa.

C.3.- Pero aquí surge el primer problema: ¿La preclusión es por "agotamiento" o "consumación" del medio, o bien, por "consumición" del mismo? El punto es importante y no se trata de un aparente juego de palabras, sino de una cuestión conceptual. La preclusión se entiende como algo más que un mero mecanismo formalista, porque aquello puede afectar gravemente al derecho de defensa procesal de la contraparte. Si se trata de "agotamiento" o "consumación", estamos hablando que un medio es usado con un cierto objetivo específico; en el caso de la acción, para obtener el ejercicio formal de la tutela jurisdiccional o sentencia, y del recurso procesal, para impugnar judicialmente una resolución. Le llamo a esto "agotamiento" o "consumación" (en concordancia con la RAE), porque es necesario esperar a que el medio se agote en su misión u objetivo, es decir, que se lleve a cabo completamente. Pero esperar tal cosa, es demasiado para las legítimas expectativas procesales de las partes, pues aquello supondrá que ya la contraria habría evacuado y exhibido su defensa, en base a la información suministrada por la que presentó el medio. Esto y los cambios que permitirían, pueden afectar la fundamental garantía de defensa. Por lo dicho, se vuelve preferible, justificadamente, la opción por la preclusión imputada a la "consumición", es decir, por el ejercicio de la facultad más otros requisitos, sin esperar al agotamiento o consumación de la misma, ya que protege las expectativas procesales, al darle estabilidad a las mismas (vid. infra C.5).

C.4.- Por esta vía los procesos van avanzando hacia su conclusión. Una vez ejercida la facultad procesal ya no se puede renovar en otro momento temporal, y sólo queda evacuar otros trámites. De esta guisa, una de las perspectivas más relevantes del punto, estriba en la cuestión de la consumición de los recursos procesales, los cuales se presentan en el procedimiento como una de las últimas etapas del proceso.

En general, las resoluciones judiciales con que se clausura un cierto tema procesal son recurribles, abriéndose, desde esta perspectiva, el proceso en otra fase: la de impugnación; se abre completamente, es decir, en el hecho y en el Derecho, como en la apelación, o bien, limitadamente, sea restringida al Derecho solamente, como en el recurso de casación y de nulidad, o circunscrita a un cierto hecho, como en ciertas modalidades del recurso de reposición con causal por error de hecho.

Al utilizarse los recursos procesales en contra de las resoluciones, se consumen, y ya no quedarán más recursos. Así, se marcará un límite a las facultades de impugnación, produciéndose la inimpugnabilidad de la resolución de que se trate. Y tal consumición contribuye a formar el carácter de ejecutoriedad de una resolución. Esto se corrobora en el art. 174 CPC, cuando 
Sobre preclusiones procesales en el derecho chileno en tiempo de reformas.

Ensayo de una teoría general desde un enfoque valorativo jurídico.

enuncia: "Se entenderá... ejecutoriada una resolución... desde que se notifique el decreto que la mande cumplir, una vez que terminen los recursos deducidos".

C.5.- ¿Cuándo se entiende consumida la facultad? Se consume cuando se entiende que toma la vía o hace uso del medio, es decir, cuando efectivamente ejerce la facultad, sea de recurrir o de interponer la excepción. Pero, esta simple regla requiere una mayor concreción, en vista a la clase de procedimiento de que se trate y la clase de acto de que hablemos, y teniendo en vistas la ratio de la preclusión (además, es preciso no confundirla con otras manifestaciones preclusivas).

C.5.1- Tratándose de actos escritos, se puede producir la preclusión por consumición, cuando:

a) se presenta el escrito,

b) es examinado y proveído por el tribunal, y, además,

c) es notificado o tomado conocimiento la contraria;

La posición “ " $a$ ", señala que si ya se practicó el pretendido acto, entonces ya no es posible corregirlo, mejorarlo o repetirlo. Ello porque se afectaría la idea excluida de repetición de actos procesales. Sin embargo, nuestra práctica no se inclina por tal solución. En general, presentado cualquier escrito, siempre se puede retirar, sin tener efectos preclusivos. Se pide el escrito y se destruyen las copias. Porque, no obstante ser formales los aspectos escriturados, ello no alcanza para cercenar cualquier posible flexibilización, en especial, en vistas del mejor ejercicio del derecho de defensa (garantido en el art. $19 \mathrm{n}^{\circ} 3$ inc. 2 CPR). En tanto no menoscabe procesalmente a la parte contraria. Esto es concordante con que no se pueda retirar ninguna pieza del proceso, por la propia parte, sin previa resolución del juez (art. 29 inc. 2 CPC). Antes de la incorporación se permite el retiro del escrito que contiene el acto, solución que es abarcada también por el art. 148 CPC, sobre retiro de demandas (aunque ésta va más allá por razones particulares).

La posición " $b$ ", supone que entrado el escrito procesal dentro de la esfera jurisdiccional se produce la consumición, al ser emitido el mero proveimiento, usualmente, de "traslado". La razón sería que ello ya supone un avance hacia la aplicación de la tutela y la prontitud. No obstante, y si bien es cierto que implica una mayor flexibilidad que la posición anterior, la mencionada exigencia no dice relación alguna con la afectación del derecho de defensa de ambas partes. El hecho de estar proveída, y permitir su retiro o cambio, no afecta en nada a la garantía de defensa. Luego, desde el punto de vista procedimental, las normas de ritualidad contemplan en estos juicios límites máximos razonables, frente a los cuales se puede llegar a ejercer una facultad procesal. Por lo que, el cambio o retiro del acto dentro de los límites temporales, supone hallarse dentro de los límites razonables de prontitud del juzgamiento. Además, es de considerar que las resoluciones no se conocen si no una vez que son notificadas 
oficialmente, lo que usualmente se realiza por el estado diario. Previo a ello el juez siempre puede cambiar su resolución (vid., p.ej., el art. 182 CPC). Es más, si fuese cierta la tesis analizada, iría en contra de la posibilidad que contempla el art. 148 p. $1^{\text {a }}$ CPC de retiro de demanda, e incluso de la facultad de enmendar la demanda del art. 261 CPC, una vez que han sido proveídas.

La opción "c" permite considerar que antes de finalizar el proceso de dar eficacia a la resolución que provee, la parte puede hacerle todo tipo de cambios, sin afectar su facultad procesal. De esto podemos referir tanto a la demanda como a los recursos procesales. La razón de ello, estriba en que antes de la comunicación puesta a la contraria, no habría afectación a la certeza procesal de la contraparte, ni, por ende, a su derecho de defensa (ratio de la preclusión y que muestra que la preclusión no es por agotamiento). También es posible observar que la resolución una vez que es emitida, inmediatamente es comunicada al público mediante el estado diario (art. 50 CPC), y luego de ello no puede ser borrada, ni cambiada de oficio (vid., p.ej., art. 182 CPC). Igualmente, vemos que la demanda, puede ser afectada con su retiro antes de ser notificada, según el art. 148 CPC $^{99}$ y se permite enmendarla por el art. 261 CPC (las modificaciones se entenderán incluso como una demanda nueva $)^{100}$. Pero tal solución, en los demás casos -como de interposición de recursos-, puede provocar un alargamiento del proceso metiendo y sacando escritos con la misma facultad. La barrera para ello, el Derecho Procesal la encuentra en el acompañamiento de otra subfigura: la preclusión por falta de oportunidad. De esta manera, no obstante se retire el acto, el plazo o el término le podrán coto fatal pero razonable a la reiteración. Por lo demás, el lector debe considerar que tales medios, son concreción del derecho de defensa de su posición procesal (garantido por la Constitución), y ningún juez de cualquier nivel está facultado por el Derecho, ni expresa ni interpretativamente, a entrometerse en un acto que es propio de la defensa de intereses de parte (y, por ende, ajeno a aquéllos), en tanto no sea para velar por la no afectación de los valores fundamentales del debido proceso; el resto es sólo una intromisión ilegítima.

C.5.2.- En el caso de los actos orales, es decir, en audiencia, tomando en cuenta las razones antes mencionadas (en lo pertinente) y, especialmente, la relativa desformalización, la solución es la misma, pero adquiere una tonalidad diferente, por el contexto en que se desenvuelve. La

La especialidad de que pueda hacerse el retiro después de la notificación por el estado, radica en que si bien el demandado es arrastrado al juicio desde el inicio, con la sola demanda, ello no materializa su afectación sino una vez que es emplazado, ahí es cuando usualmente toma conocimiento de los actos y puede hacer uso efectivo y consciente de su derecho de defensa.

100 Por su parte, la especialidad de la solución del art. 261 CPC respecto a la falta de fijeza de las condiciones, incluso luego de notificada, estriba en que, por una parte, al inicio parece ser el demandante a quien urge casi exclusivamente llegar al fin del proceso, dada la calidad de arrastrado al proceso del sujeto pasivo. Y el derecho de defensa se salvaguarda, pues se pone límite infranqueable a la mutabilidad: ello sólo se puede producir antes de la contestación, pues ampara que la última estrategia procesal que se muestra (usualmente en la contestación) sea la del demandado. Además, al ocurrir la mutación antes de la contestación, se debe realizar una nueva notificación personal, como si dicha enmienda fuese una nueva demanda. 
Sobre preclusiones procesales en el derecho chileno en tiempo de reformas.

Ensayo de una teoría general desde un enfoque valorativo jurídico.

oralidad trae consigo la inmediación, tanto para el juez como para la contraria, por lo que la sucesión de actos es rapidísima. Es por ello que la presentación oral que haga la parte, es de inmediato resuelta por el tribunal con un traslado o dando la palabra a la contraria. Y ahí la contraria debe responder en base a la información proporcionada y la expectativa generada por la propia contraparte. En tal evento, teniendo la palabra la contraria debe organizar su estrategia, por lo que ya estará formulada y consumida la facultad procesal, por ende, precluida (sin poder repetirse o modificarse el acto).

C.6.- Pero no siempre ocurre que toda facultad precluya por consumición. Es posible que la ley habilite la facultad de volver a repetir el acto, no fuera del proceso, sino dentro del mismo. Puede haber razones de protección a la mejor defensa procesal, que así lo aconsejen por ejemplo. El caso más conocido en nuestro Derecho Procesal es el de la absolución de posiciones. La ley procesal civil permite que, no obstante se haya citado y evacuado la declaración de parte, y que en consideración de quien pidió dicha citación, haya quedado algún punto oscuro o hubiese obtenido nueva información, se pueda citar nuevamente a declarar a la contraria, según el art. 385 inc. 2 CPC.

Además, es posible que no obstante se haya terminado la línea continua de impugnaciones, aún el Derecho Procesal reserve la facultad de plantear nuevamente la cuestión en una etapa diferente. La idea de trasfondo es intentar que el proceso no se desgrane en largas cadenas impugnativas, sino por el contrario, concentrar la discusión y reenviar el problema a una revisión postrera. Así, p.ej., si se desestima una incidencia de nulidad de todo lo obrado por falta de emplazamiento, y la parte recurre de reposición y de apelación, siéndole rechazados sus recursos en ambas instancias, entonces su vía continua llega hasta dicho momento nada más, y la casación contra la última resolución la encontrará vedada ${ }^{101}$. Sin embargo, puede renovarse la discusión planteándola en el recurso de casación en la forma, pero contra la sentencia definitiva. En efecto, el art. $768 \mathrm{n}^{\circ} 9$ CPC dispone la procedencia de la casación cuando se ha faltado a un trámite o diligencia declarados esenciales por la ley, y que al ponerse en relación con el art. 795 n $^{\circ} 1$ CPC, que contempla como trámite esencial, el "emplazamiento de las partes en la forma prescrita por la ley", se habilita para seguir, con salto, la discusión, no obstante que, en principio, por la línea procesal seguida, pareciese que se hubiesen consumido los recursos procesales destinados al efecto. Como ha dicho la judicatura, tal agotamiento aparente de la vía es necesario para efectos de "preparar" el recurso de casación en la forma (reclamando de la falta, ejerciendo oportunamente y en todos sus grados los recursos establecidos por la ley", según manda el art. $769 \mathrm{CPC})^{102}$.

101 Corte de Apelaciones de Santiago, sentencia 13 abril del 2002, causa rol 1071-1999. Jurisprudencia del Recurso de Casación en la Forma y en el Fondo, (J.L. Zavala, edit.). Punto Lex, Santiago 2007, p. 5.

102 La Corte Suprema en un caso de precario, donde se alegó casación por falta de emplazamiento a alguno de los ocupantes de un inmueble, dictaminó que la parte recurrente no podía entablar el recurso de manera correcta, 
Finalmente, es menester destacar el caso del recurso de casación en la forma en contra de sentencia definitivas, en que si bien es ejercido por la parte perdidosa (junto con la apelación) en contra de la sentencia de primera instancia, e incluso agotado con su rechazo, es aceptado por la práctica judicial presentar nuevamente otro recurso de casación en la forma, incluso por esa misma parte, pero ahora en contra de la sentencia definitiva segunda de instancia, y para efectos de que sea conocido por la Corte Suprema ${ }^{103}$, con base en el mero cumplimiento de las causales de procedencia del mismo recurso.

C.7.- Hemos visto que la preclusión por consumir la facultad, en relación con los recursos, produce la inimpugnabilidad de las resoluciones, indispensable para la formación de la autoridad de la cosa juzgada. Esta preclusión se haya en franca pugna con la absolución de la instancia y la posibilidad de renovar la acción en el mismo proceso. Es posible que los tribunales emitan una resolución meramente formal, que no resuelva el asunto, sino que mediante una interlocutoria den por clausurado el juicio. Es decir, no hay una sentencia de fondo que ejerza la tutela jurisdiccional, ni aun formalmente: no hay agotamiento de la acción. El problema tiene muchas aristas o enfoques, pero aquí desde el punto de vista de la preclusión es que lo miramos. Se presenta de manera especial en materia penal, mediante "dos figuras" análogas a la absolución de la instancia: la del sobreseimiento temporal por falta de pruebas (del viejo CPP) o la facultad de no perseverar en la investigación (art. 248-C inc. 2 parte $1^{\text {a }}$ CPP). En esta última, una vez decretado el cierre de la potestad de investigar, se permite renovar la facultad investigativa ya utilizada en el mismo proceso, afectando de esta manera a la preclusión por consumición: la facultad fue utilizada y el proceso clausurado, y no obstante se reutiliza, reabriéndose el proceso penal, en su fase investigativa. De esta manera, se afecta la certeza jurídica y la prontitud del juzgamiento, pues permite tener extendido el estado de incerteza del ciudadano, no obstante estar formalmente terminado el proceso, con la posibilidad de renovación. Para A. Carocca, habría una solución procesal: la caducidad del proceso, por abandono de la acción; mientras que en M.I. Horvitz y J. López se señala que sólo puede esperarse el plazo de prescripción. A mi juicio, la norma constituye un fraude al principio de la

porque "la parte que lo entabla no reclamó oportunamente y en todos sus grados del vicio en el que ahora pretende fundar el recurso, ya que según consta en autos sólo apeló del fallo de primer grado" (sentencia de 16 marzo de 2007, causa rol 2380-2005, cit. nota n. 101, p. 21).

103 Vid. así el caso penal denominado 'desmalezado de la RPC'. Primero la Corte de Apelaciones de Valparaíso, sentencia de 12 de septiembre de 2007, rol 3235-2007 y luego la Corte Suprema, sentencia de 24 de marzo de 2009, rol 649-2008, redactada por N. Segura). Esta última precisa ciertas limitaciones, como que "tampoco es procedente prestar acogida a un recurso de casación en la forma que se dirige contra el fallo que se pronuncia sobre idéntico recurso, y no contra el pronunciamiento que, como tribunal de instancia, ha emitido la Corte de Apelaciones respectiva" (consid. 18). Este no ha sido el criterio respecto de la procedencia del recurso de queja ante la Corte Suprema impugnando la sentencia de recurso de queja de la Corte de Apelaciones de Santiago, pues la tercera sala del máximo tribunal ha decretado admisible dicho recurso, en causa indemnizatoria por el bullado caso conocido como 'cárceles concesionadas', o 'Muñoz Ortuzar con Comisión Arbitral', rol 6004-2007. 
Sobre preclusiones procesales en el derecho chileno en tiempo de reformas.

Ensayo de una teoría general desde un enfoque valorativo jurídico.

única persecución, pues evita su aplicación, por lo que debiera ser anulada constitucionalmente la ley ${ }^{104}$.

\section{8.- Preclusión y congruencia procesal}

La preclusión es una de las figuras más básicas del Derecho Procesal y, en tal sentido, constituye un instrumento mediante el cual, en parte, se concretiza en los procesos la congruencia procesal. Esta última mira hacia la necesaria línea del eventual debate y decisión del asunto ¿para qué? pues es un instrumento para posibilitar una defensa racional; es decir, que las partes, tanto la activa como la pasiva, puedan reconstruir lo que ocurre y pueda ocurrir en el proceso, y tomar dichas consideraciones como razones para definir su actuación procesal, en vistas al objetivo de obtener del proceso lo que busquen de acuerdo a su posición procesal ${ }^{105}$. De todas formas, la influencia del principio de congruencia es variable de acuerdo a las consideraciones jurídicas que pesan en la configuración de cada proceso. p.ej., mirada las cosas desde el punto del sujeto pasivo, en materia civil no puede romperse la congruencia en el tópico de la prescripción extintiva, mientras que en materia penal, en el mismo tópico, sí se puede.

La especial relación de la preclusión con la fijación de las situaciones procesales en los casos singulares, mediante sus consecuencias cercenadoras tanto para las partes como el juez, a efectos de consideraciones valorativas, la hace particularmente apta para concurrir en auxilio de la conformación de la congruencia procesal, sirviéndose ésta, entonces, de aquélla para sus objetivos. Así, en cada etapa del proceso, la preclusión limita las potestades de los intervinientes para ir alterando el debate, de manera de ir realizando la congruencia progresiva de la discusión. Por su parte, dado el trasfondo del derecho de defensa de la congruencia, la relación entre estas dos figuras jurídicas -mirada en sentido inverso- habilita a sostener que la congruencia, dentro de su parcela, le marca el rumbo o dirección a las preclusiones procesales que se den en el juicio. De esta guisa, observemos una subregla de la congruencia, la prohibición de mutatio libelli, en especial, en los nuevos procesos orales.

Para cualquier actor, su pretensión, luego de contestada, ya no podrá ser cambiada, porque le ha precluido la opción de cambio, limitando así la desformalización del proceso oral. Es un

104 A. Carocca, Manual El Nuevo Sistema Procesal Penal, $3^{\text {a }}$ edic. Lexis Nexis, Santiago, 2005, p. 207; M.I. Horvitz y J. López Masle, Derecho, cit. nota n. 47, t. I, p. 587; E. Gandulfo. 2005. "Consideraciones acerca de la Prescripción de la Acción Penal y el Giro al Descubierto de Cheque, en Relación con el Viejo y el Nuevo Ordenamiento Procesal Penal", Gaceta Jurídica No 306, p. 33, n. 34, y p. 34.

105 La afectación y protección de la congruencia para las dos partes, puede verse con mucha claridad en los procedimientos en que la defensa del sujeto pasivo es restringida. p.ej., en los procesos civiles ejecutivos, aquella figura también protege al actor en la búsqueda de lo pretendido, no dando lo mismo si el juez se aparta de la defensa expuesta por el ejecutado. Situación similar puede verse en los recursos de Derecho estricto, tanto en materia civil como penal (aunque de manera variable). 
subprincipio del derecho de defensa, que el sujeto pasivo (civil o penal) debe tener, como regla generalísima, la última palabra. Porque su situación es de ser arrastrado a un proceso, por la voluntad del actor, quien cuenta con todo el tiempo de prescripción o caducidad para preparar la formalización y desarrollo de su pretensión, lo que muestra una desigual posición procesal en favor de este último ${ }^{106}$. La última palabra no es simplemente que diga lo último en cualquier circunstancia, sino que debe ser entendido en relación con la defensa procesal. Se trata de que tenga la última palabra en lo relativo a la estrategia procesal (la cual es la que determina cómo se ejercerá en concreto todo el derecho de defensa ${ }^{107}$ ). Es decir, una vez fijada la estrategia por el sujeto pasivo, lo que se realiza mediante la contestación, al exhibir públicamente la base de su estrategia, el actor no puede (ni el juez) alterar la demanda de manera sustancial, cambiándola $^{108}$. De ahí que la ley establezca toda una regulación protectora en tal sentido: exija notificación con las copias íntegras para informarse del ataque y planificar la defensa (art. 40 CPC) so pena de nulidad (art. 80 CPC), y da una antelación mínima de 10 a 15 días para preparar la estrategia y sus medios (arts. 58 inc. 1 y 59 inc. 2 LTF, arts. 451 inc. 1 y 452 inc. 2 CdT), la misma ratio corre para la reconvención (art. 58 LTF). Es más, reformado el punto, la ley ya ni siquiera da la opción de ratificar, sino que en la audiencia sólo se procede a hacer una "relación breve y sintética" o "relación somera" que "harán las partes" en familia o "hará el juez" en lo laboral, "del contenido de la demanda, de la contestación y de la reconvención que se haya deducido", mas no cambiar la demanda (art. 61 n $^{\circ} 1$ LTF y art. 453 n' 1 CdT). Por aplicación subsidiaria de la norma del art. 261 CPC, en relación con el art. 3 CPC y los arts. 27 LTF y 432 inc. $1 \mathrm{CdT}$, se permite modificarla antes de la evacuación de la contestación, de manera de no afectar la defensa estratégica ${ }^{109}$. Pero si se advierte bien, es mediante dicha norma procesal civil que, además, se veda la modificación de la pretensión una vez contestada la demanda, en cuanto a poder cambiar la acción. En suma, la alteración de la demanda postrera implica dejar al demandado desprotegido, luego de la exhibición de sus armas ${ }^{110}$. En relación

Esto se ve de manera extrema en el proceso penal, en que el órgano acusador cuenta con todo el tiempo de la investigación para reunir el material probatorio de cargo y de descargo, que su ley le impone buscar (art. 3 LMP), para construir su acusación.

107 Como señala la judicatura: "Como se ejercita una acción determinada... el demandado organiza su defensa en base a aquella pretensión, tanto en sus argumentaciones jurídicas como en las probanzas de los hechos, la que dirige a combatir la acción que se ha propuesto" (Corte de Apelaciones de Concepción, caso 'Euvet con Ríos', sentencia de 17 de junio de 1993, consid. 13, redactada por la pluma del juez D. Peñailillo Arévalo, RDJ., t. 90, 1993, sec. $2^{\text {a }}$, p. 84 y ss.). En la teoría procesal chilena, vid. H. Botto, La Congruencia Procesal, Lerner, Córdoba, 2006, pp. 94 y ss.

108 Sobre las alegaciones y pretensiones complementarias, que no alteran el proceso vid. D. Palomo Vélez. 2005. "La Audiencia Previa y el Modelo Procesal Civil: Consideraciones en Torno a Una Pieza Clave", Revista Chilena de Derecho, № 2, v. 32, pp. 290 y 291.

109 Podría operar un reenvío -según sugerencia del colega Gonzalo Céspedes Proto- desde la LTF al libro primero del CPC y de éste al libro segundo del CPC, todo para llenar las lagunas de la LTF, en tanto las soluciones normativas del libro segundo, sean compatibles con los caracteres específicos del proceso oral de familia.

110 La judicatura ha censurado incluso la alteración del "planteamiento de la actora", ocurrida más tarde por el propio juez en el fallo, pues entonces dicha actitud "encuadra los hechos en otra situación jurídica que llega a 
Sobre preclusiones procesales en el derecho chileno en tiempo de reformas.

Ensayo de una teoría general desde un enfoque valorativo jurídico.

con la contestación de la demanda, ésta sólo puede realizarse en determinado tiempo legal y ratificada en la audiencia preparatoria, antes de la fase de ofrecimiento de medios probatorios de la acreditación de dicha contestación. Y si bien es cierto que su ausencia no tiene mayor gravedad con respecto al rechazo de la pretensión con meras alegaciones, sí lo tiene, en general, con relación a las "excepciones iuris" o "contra-derechos" que deban ser alegados por el sujeto pasivo para que sean acogidos, como la prescripción; si la ley no permite presentarlos después, se pierden absolutamente ${ }^{111}$ (se hace la salvedad de ciertas excepciones mixtas o anómalas, que pueden interponerse en la audiencia preparatoria o en la de juicio -art. $265 \mathrm{CPP}$ ).

En suma, de acuerdo a la propuesta de construcción de la preclusión, la concordancia del derecho de defensa entre ambas figuras, las hace compatibles para aunarse en específicos ámbitos a fin de tutelar de mejor manera este valor jurídico de la defensa que se haya de trasfondo.

\section{9.- Forma de hacer valer la preclusión}

El tribunal puede hacerla valer de oficio o a petición de parte, en general, pues mira a la correcta tramitación del proceso, basado en ciertas normas procedimentales indisponibles, sea individualmente o en conjunto. Aquí las normas de preclusión apuntan a la concreción del debido proceso y sus garantías involucradas en esta figura. Y tal conclusión se cumple aún cuando las partes hayan sido las que pusieron las reglas preclusivas, como en el caso del arbitraje y la partición, o en la prueba en materia oral, ya que incluso allí puede afectarse el correcto orden consecutivo procesal, con sus valores involucrados.

Observemos que en uno de los casos de mayor atenuación de la preclusión, como es el plazo judicial, el tribunal aún tiene la facultad de declarar evacuado el trámite en rebeldía ex officio, de acuerdo al art. 78 CPC.

\section{0.- ¿Precluye la preclusión?}

Este problema, que más bien parece un juego de trabalenguas, puede ser muy interesante en relación con el tema anterior. Lo primero a precisar es que la preclusión no precluye, sino que son las facultades procesales de poder reclamarla y, consecuencialmente, las potestades de

importar el cambio de la acción, el demandado queda sin defensa respecto de ella y sin siquiera la posibilidad de reorganizar lo que ha traído, atendido el estado del proceso". Corte de Apelaciones de Concepción, 'Euvet con Ríos', cit. nota n. 107, Ibíd., y la misma con iguales argumentos en 'Quezada Casas y otros con Estado de Chile', sentencia de 19 de enero de 2007, rol 3464-2006, revista Leyes \& Sentencias, № 34, 2007, pp. 101 y ss.

111 Vid. M. Cappelletti, El Proceso Civil en el Derecho Comparado. Ara Editores, Lima, 2006, pp. 41 a 42 ; G. Chiovenda, Principios, cit. nota n. 19, t. II, pp. 315 a 319. 
declararla. En efecto, como se señaló al inicio del trabajo, la pérdida o extinción de los poderes que produce la preclusión, es de tipo normativa, lo que no excluye que de hecho pueda llevarse a efecto el acto.

La situación más conocida de "preclusión de la preclusión” puede darse cuando, en algún punto del proceso, éste pueda contener alguna irregularidad en contra del correcto orden jurídico procesal, p.ej., a causa de la presentación de actos incompatibles (que es la más usual y compleja de determinar en los concretos procesos). No obstante -a mi juicio- la suma preclusión de la sentencia definitiva, debería poner fin a los vicios no reclamados e incluso hacer precluir una preclusión nunca alegada y desatendida por el tribunal del caso.

En igual sentido, las preclusiones de las subfases o de las audiencias también podrían producir "preclusión de la preclusión". R. Tavolari, siguiendo una observación de A. de la Oliva, presenta un ejemplo complejo pero esclarecedor. Señala que la comparecencia fuera de plazo a realizar algún acto, "es en sí misma un defecto insubsanable, pero no genera nulidad absoluta desde que si el órgano jurisdiccional la admite y la parte contraria no recurre, el proceso seguirá su curso, sin contener en su seno vicio de nulidad absoluta"112. De esta guisa, la realización de un acto, p.ej., la presentación de una lista de testigos, cuya facultad procesal de evacuación ha precluido por tiempo, y que no ha sido reclamada ni decretada oportunamente, no hace decaer tal acto. El art. $161 \mathrm{CPP}$ contiene una norma que corrobora tal decisión: "La solicitud de nulidad presentada extemporáneamente será declarada inadmisible" (a menos que se trate de un motivo absoluto de nulidad, como la del art. $160 \mathrm{CPP}$ ). Igual cosa presenta el art. 25 LTF: "Toda nulidad queda subsanada si la parte perjudicada no reclama del vicio oportunamente". Pero se presenta una contradicción en principio, porque: $i$.- si está fuera de plazo y es insubsanable (como dice Tavolari), no se ve cómo ii.- pueda sanearse el vicio de la inoportunidad que anularía el acto, y más aún si la falta al plazo produce la caducidad. Uno de los dos cuernos del dilema debería caer. La Ley de Tribunales de Familia, parece pronunciarse a favor de eliminar el cuerno de la no subsanación y dejar la posibilidad de saneamiento. Pero aquí debemos explicar esto con algo de profundidad.

La nulidad es la pérdida de validez de algo, es decir, de su fuerza obligatoria. Como es bien sabido, sólo se predica validez respecto del mundo del deber ser, es decir, del mundo normativo: de las normas. Lo que pierde validez procesal es la norma individual llamada "resolución judicial". No se declara la nulidad de los actos propiamente tales ${ }^{113}$. Éstos pueden

\footnotetext{
112 R. Tavolari, "Reflexiones", cit. nota n. 36, p. 6 (la cursiva es mía).

113 Los actos no son normas -aunque mediante ellos pueden constituirse normas. En el caso de, p.ej., la demanda, en que se pide la tutela jurisdiccional, ella no obliga al juez alguna cosa, sino que son las normas de inexcusabilidad y de procedimiento las que lo obligan a darle tramitación, frente al supuesto particular de una demanda. Si no existieran dichas normas, sería como cualquier petición.
} 
Sobre preclusiones procesales en el derecho chileno en tiempo de reformas.

Ensayo de una teoría general desde un enfoque valorativo jurídico.

ser existentes o inexistentes, pueden ser admitidos o no, pero no hay nada a que privar de fuerza obligatoria ${ }^{114}$. En el caso en examen, se trata de la resolución que decretó admisible el acto de pedir o de presentar, la que estaría afectada de vicio de legalidad, a causa de que el acto de ejecución de una facultad normativa, carecía de esa facultad que lo respaldase. El problema que se plantea es que, no obstante que la facultad estaba caducada, el acto fue declarado admisible por la resolución judicial y, por tanto, es la validez de tal resolución la que obliga a tenerlo en consideración jurídicamente.

Ahora bien, si no se reclama en contra de la resolución de admisión, entonces tal resolución queda firme, precluyendo la opción de revisarla, incluso de manera refleja para futuros jueces que deban revisar el proceso en general (sale fuera de su ámbito de competencia). Pero lo más importante es que, no obstante que se produjo la extinción de la facultad procesal de realizar el acto, por inoportunidad, y que esta situación se mantiene tal cual -por insubsanable-, la resolución judicial de admisión se encontrará firme en su orden de considerar jurídico-procesalmente a tal acto ${ }^{115}$. En cierta medida, la preclusión por inoportunidad obrada en el proceso, no debe ser tomada en cuenta (como si aquella preclusión hubiese precluido).

114 Lo problemático de los actos es que, a su régimen de admisibilidad se le confunde, al menos parcialmente, con el de la invalidez, a causa de que al examen de admisibilidad se le aplican a veces, en analogía, el régimen de la nulidad procesal, en especial, en lo relativo al procedimiento de constitución de la resolución judicial, y por razón de economía jurídica, a efectos de no repetir una misma reglamentación casi por completo. No obstante son estructuralmente distintos y pertenecen a esferas diversas.

115 Lo mismo ha de ocurrir, cuando la parte, dándose cuenta del vicio, es decir, de la caducidad preclusiva de la facultad procesal, reclama del vicio mediante apelación, siéndole negada. Pero en tal caso, es la validez o fuerza obligatoria de la resolución jurisdiccional, la que impone la consideración futura de la realidad jurídica a que deben atenerse las partes, el propio tribunal de la instancia y los tribunales revisores. Para la parte reclamante, además, si ejerció el último recurso, se le producirá una preclusión por consumición. 
190 Revista IUs et PraXis - AÑo 15 - № 1 